Florida International University FIU Digital Commons

4-1-2005

\title{
Architecture as contextual re-interpretation : a mixed-use cultural center in Old Havana, Cuba
}

Gabriel Fuentes

Florida International University

DOI: $10.25148 /$ etd.FI15101459

Follow this and additional works at: https://digitalcommons.fiu.edu/etd

Part of the Urban, Community and Regional Planning Commons

\section{Recommended Citation}

Fuentes, Gabriel, "Architecture as contextual re-interpretation : a mixed-use cultural center in Old Havana, Cuba" (2005). FIU

Electronic Theses and Dissertations. 3594.

https://digitalcommons.fiu.edu/etd/3594 
FLORIDA INTERNATIONAL UNIVERSITY

Miami, Florida

ARCHITECTURE AS CONTEXTUAL RE-INTERPRETATION: A MIXLD-IISE CIILTURAL.

CENTER IN OLD HAVANA, CUBA

A thesis submitted in partial fulfillment of the

requirements for the degree of

MASTER OF ARCHITECTURE

by

Gabriel Fuentes

2005 
To: Dean Juan Antonio Bueno

School of Architecture

This thesis, written by Gabriel Fuentes, and entitled Architecture as Contextual Re-Interpretation: A Mixed-Use Cultural Center in Old Havana, Cuba, having been approved in respect to style and intellectual content, is referred to you for judgment.

We have read this thesis and recommend that it be approved.

Juan Antonio Bueno

Alice Gray Read

Nicolás Quintana, Major Professor

Date of Defense: April 1, 2005

The thesis of Gabriel Fuentes is approved.

Dean Juan Antonio Bueno

School of Architecture

Dean Douglas Wartzok University Graduate School

Florida International University, 2005 
(C) Copyright 2005 by Gabriel Fuentes

All rights reserved. 


\section{DEDICATION}

I dedicate this thesis my wife Yeila, without whose loving support, patience, and understanding could have in no way, shape, and form been possible. You have stuck by me through thick and thin and have made the completion of this thesis not only a reality, but worthwhile. I love you dearly and am thrilled to share this accomplishment with you. 


\section{ACKNOWLEDGMENTS}

I would like to extend a warm thank you to my thesis committee for their firm support and guidance. Professor Gray Read's persistence and dedication has helped me keep focused throughout this process. Professor Juan Bueno has helped me better understand the important relationship between landscape and architecture. Finally, Professor Nicolás Quintana has proven to be an inspiration to me both academically and personally. His passion for architecture and his native Havana has moved me to pursue excellence not only in the execution of this thesis, but in many aspects of life. Few professors have the ability to impact their students the way he has impacted me and I am privileged to have formed a friendship with him throughout my time at the School of Architecture.

I would also like to thank my family, particularly my mother, grandparents, and sister as well as my wife's immediate family. Their support has motivated me to stay on course and has proven valuable every step of the way. Without their support, this thesis would not have been possible.

Special thanks to the Florida International University's Cuban Research Institute (CRI) and Uva de Aragon for giving me the opportunity to travel to Havana (and working so hard to get me there) and experience such a beautiful city.

Finally, I would like to thank Mercedes, Luis Rene, and Yhosvany de Oca for going the extra mile to make my stay in Havana comfortable, insightful, and productive. I'm delighted to have gained their friendship while abroad.

I would like to extend my sincere apologies to those who I may have unintentionally left out. 
ABSTRACT OF THE THESIS

ARCHITECTURE AS CONTEXIUAL RE-INTERPRI:TA'TION: A MIXED-USE CULTURAL.

CENTER IN OLD HAVANA, CUBA

by

Gabriel Fuentes

Florida International University, 2005

Miami, Florida

Professor Nicolás Quintana, Major Professor

This thesis addresses contextual design in the city, particularly the design of contemporary architecture in historic places.

The research focuses on an analysis of Old Havana`s urban architecture, particularly the spatial qualities of colonial Cuban houses as well as visual, social, and functional qualities of their urban façades. Additionally, I analyze specific mid-twentieth century houses that reinterpret Cuba's colonial architecture in order to derive architectural principles that are tested in my design process.

The design project is a mixed-use cultural center at the Plaza Vieja in Old Havana, Cuba. As a cultural destination currently undergoing restoration, the Plaza Vieja is an appropriate place to propose a contemporary project that reinterprets Havana's historic context. The cultural center embodies a synthesis between old and new ideas. 


\section{TABLE OF CONTENTS}

CHAPTER

PAGE

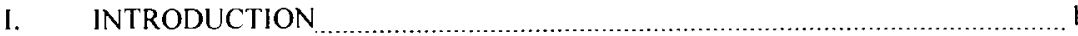

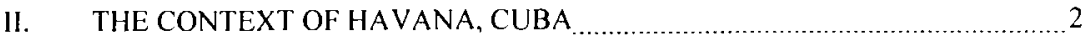

The Colonial Cuban House: Thresholds and Transitional Spaces 2

The Plazas of Old Havana: The Urban Façade 7

- The Façade as Part of an Urban Composition: The Plaza Vieja 7

- The Façade as a Generator of Social Activity: Portales and Balconies 9

- The Façade as a Climatic Filter: Persianas and Vitrales 11

Contextual Reinterpretation in Mid-Twentieth Century Havana 14

III. CASE STUDIES

Eugenio Batista-Eutimio Falla Bonet House, 1939

Mario Romañach and Silverio Bosch-José Noval Cueto House, 1949

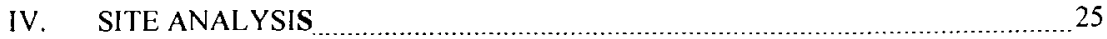

Brief History of the Plaza Vieja $\quad 25$

Graphic Analysis $\quad 26$

V. DESIGN PROPOSAL: MIXED-USE CULTURAL CENTER _....................... 30

$\begin{array}{ll}\text { Program Breakdown } & 30\end{array}$

Process Design Sketches 31

Final Project 34

VI. CONCLUSION

LIST OF REFERENCES 
FIGURE

1 Diagrams showing the thresholds and transitional spaces of the typical colonial

Cuban house in sequence

Diagram showing the spatial relationship between the urban plaza and interio

3 Diagrams showing the thresholds and transitional spaces of specific colonial houses at the Plaza Vieja

3

Photograph showing lower and upper level galeria spaces

5

Patio typology study

Existing elevation of the Plaza Vieja

Analytical collages of the Plaza Vieja and colonial building currently undergoing restoration.

$8 \quad$ Analytical section diagram showing the relationship between public space, private space, and the urban façade

Photograph showing a mediopunto vitral and persianas 13

10 Photograph showing the interplay of color and light as it penetrates the interior 13

Flyer distributed several days before the quema de los Vigñola

12 Architecture designed in Havana during the mid-twentieth century by Mario Romañach...

13 Mid-twentieth century architecture in Havana

14 Mid-twentieth century architecture in Havana

15 Front of the Eutimio Falla Bonet House 20

16 Floor plan of the Eutimio Falla Bonet House 20

17 Exploded isometric drawing of Eutimio Falla Bonet House 22
Floor plans of the José Noval Cueto House.

Plaza Vieja with parking garage

Plaza Vieja $17^{\text {th }}$ century 25

Photographic analysis of the Plaza Vieja

Character collage of the Plaza Vieja

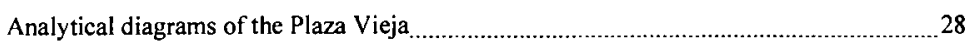

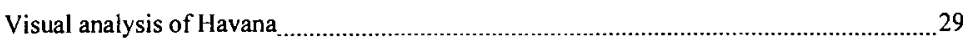

Process design sketches showing the conceptual development of the façade and courtyard.

Process design sketches showing conceptual development of the floor plan

Process design sketches showing the conceptual development of the floor plan and section

Floor plans of the proposed cultural center $\ldots$

Floor plans of the proposed cultural center

Front elevation and section detail

Proposed front elevation in context

Threshold and transitional space study ................................................................................ 39

Exploded isometric drawing showing façade assembly, materiality, and detail as well as contextual elements used and/or re-interpreted .............................................................40

Plaza Vieja before and after design proposal ................................................................... 41

Photomontage
Site plan, site section, and transverse section $\ldots$ 
Photomontage

39 Photomontage

40 Digital rendering of the courtyard

45

41 Digital rendering of a gallery (galeria) space

42 Digital rendering of the courtyard

43 Digital rendering of public, multi-functional open spaces 


\section{INTRODUCTION}

Architecture should be appropriate to its place. However, contextual architecture has been accepted by many as the cosmetic imitation of old buildings. In this thesis, I explore social, cultural, and historic issues as critical aspects of the definition of "context". The design project reinterprets Old Havana's colonial architecture within this larger context in order to provide continuity as well as a contemporary response to new conditions.

Old Havana, Cuba is an appropriate place for this investigation. Despite its current state of deterioration, many anticipate future urban development. The fear, however, is that extensive urban development might overlook its social, cultural, architectural, and urban history. This thesis proposes a contemporary design project in Old Havana that responds to both issues of place and modernity simultaneously.

During the 1940s and 50s a group of modern architects in Havana reinterpreted the spatial and functional principles of Cuba's colonial architecture in their work. In doing so, they created a genuinely modern Cuban architecture that reflected their culture as well as Modernist principles exported from Europe and North America. Because of political change, however, this period came to a fast halt. With the exception of a few works, their ideas did not reach full potential beyond suburban architecture.

In particular, Eugenio Batista and Mario Romañach were considered pioneers of contextual reinterpretation. Their architecture expressed a synthesis between tradition and modernity-looking backwards and forward at the same time. Had this period not ended prematurely, their ongoing architectural experimentation would have produced extraordinary results at the hands of a new generation of contemporary architects. In this thesis, I analyze the Eutimio Falla Bonet House by Eugenio Batista as well as the José Noval Cueto House by Mario Romañach. Following their example, my design reinterprets Havana's context in order to ensure that it retains links with its past.
In analyzing colonial Cuban houses, I have discovered the following principles:

- Articulation of thresholds and transitional spaces in between programmatic zones

- Sequential movement through thresholds and transitional spaces (generally from portal to zaguán to galeria to patio to traspatio and visa versa)

- A direct relationship to the street or plaza through portales and balconies

- Façades that respond to the tropical climate

- The façade treated as part of an urban ensemble

Eugenio Batista and Mario Romañach reinterpreted these principles in their houses by:

- Articulating thresholds and transitional spaces in flexible ways such as placing them at different heights (sectional articulation) or elongating them in order to create architectural experiences

- Choreographing various sequences of movement by providing several paths to important spaces

- Articulating façades to have a solid character facing the street while opening up towards the back facing a patio and garden

- Adapting colonial architectural elements to contemporary architectural design

By reinterpreting these principles, I propose a creative leap between mid-twentieth century suburban architecture and 21 st century urban architecture in Havana.

My methods of analysis include descriptive interpretations as well architectural graphics (two and three-dimensional diagrams, pictures, plans, and elevations) in order to analyze the architectural and urban character of Havana's historic context. Through design, I have used the understanding gained towards a contemporary resolution. 


\section{THE CONTEXT OF HAVANA, CUBA}

2 The Colonial Cuban House: Thresholds and Transitional Spaces

The colonial Cuban house is a spatially rich urban typology that has contributed to Old Havana's architectural and urban character for centuries. Typically, they were mixed-use patio buildings with rooms on the ground floor, known as accesorias, used as storage for businesses or rented to local artisans.' The living spaces were on the upper floors, accentuated by overhanging balconies that drew visual connections between private family activities and the public life of the street or plaza.

The fusion of public and private spaces in the colonial Cuban house required a careful articulation of areas through the use of thresholds and transitional spaces. These spaces, both within the interior and in their relationship to urban space, are key spatial characteristics that have given depth and dynamism to architectural and urban space in Havana throughout its history. They are worthy of analysis and reinterpretation. Through design, I have reinterpreted the spatial qualities of these elements using a contemporary architectural language that combines spatial innovation with historic sensitivity.

While both the threshold and the transitional space share similar qualities, their fundamental difference is scale. While a threshold is, by definition, an edge or a line in between two spaces, a transitional space is an area caught in between two programs. This area is not defined by any particular function but acts as an extension of multiple and, at times, contrasting activities.

Through careful study of the typical colonial house in Old Havana I have identified its thresholds and transitional spaces in sequence as:
1. The portal
2. The zaguán

Referenced from the essay Life and Death of the Courtyard House: Migration, Metissage and Assassination of a Typology by Christina Amoruso and Orestes del Castillo (ACSA, October 1997).
3. The galeria

4. The patio

5. The traspatio
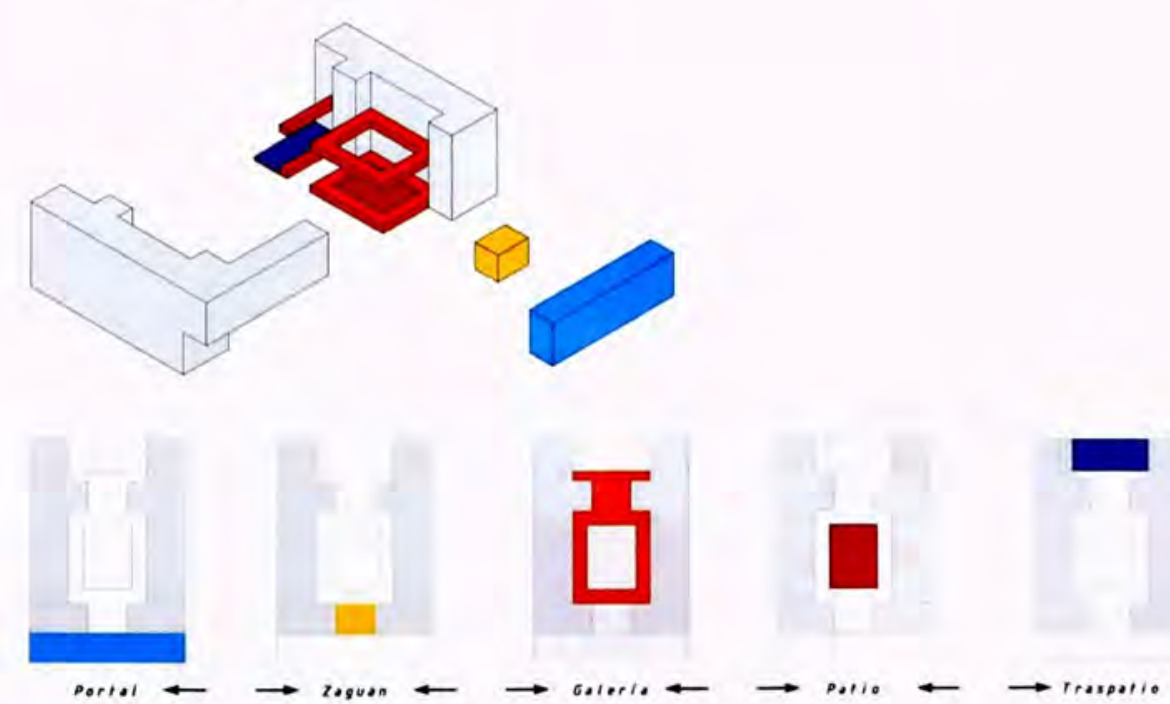

Figure 1 Diagrams showing the thresholds and transitional spaces of the typical colonial Cuban house in sequence.

Source: By author (2004)

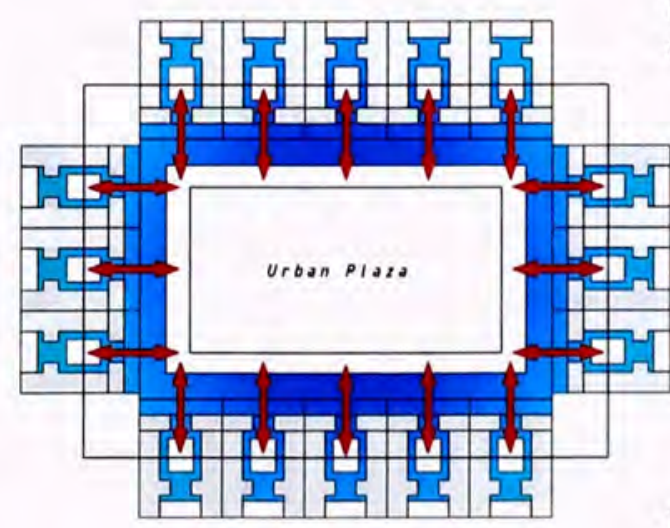

Figure 2 Diagram showing the spatial relationship

between the urban plaza and interior patios.

Source: By author (2004) 


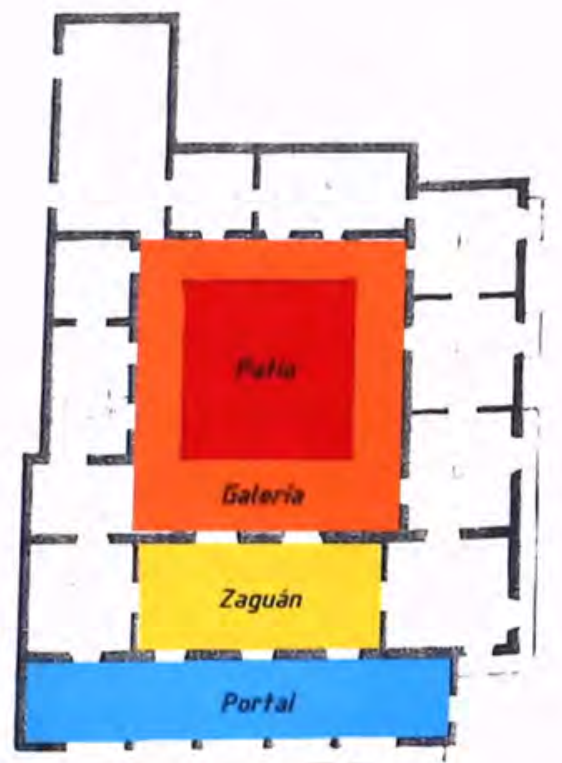

Casa del Conde de San Juan de Jaruco, 1737 Muralla 107-111, Plaza Vieja

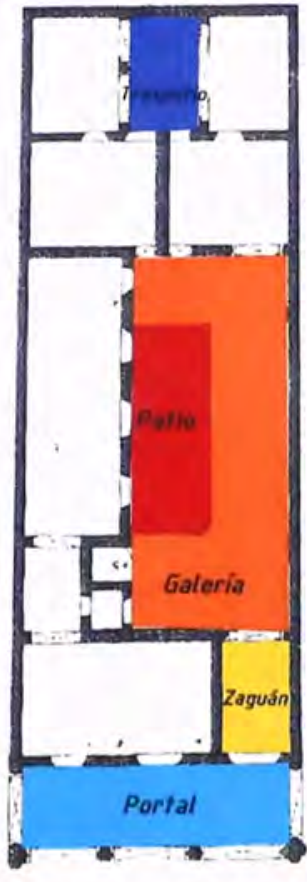

Casa del Conde de Casa Lombillo, 1745 San Ignacio 364, Plaza Vieja

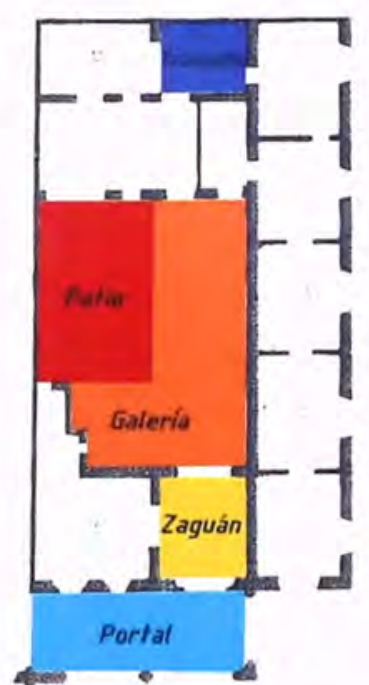

Casa de las Hermanas Cárdenas, $1805 / 1834$ San Ignacio 352, Plaza Vieja

Figure 3 Diagrams showing the thresholds and transitional spaces of specific colonial houses at the Plaza Vieja.

Source: La Habana: Guia de Arquitectura 
The use of these thresholds and transitional spaces contribute to a unique choreography of movement through various architectonic layers-sequentially articulating one's procession through the house. Figures 1 and 2 depict the sequence of these thresholds and transitional spaces and their relationship to the urban plaza.

\section{The Portal (Portico)}

The portal served as a transitional space between the public areas of the house and the urban activities of the street or plaza. In design, it also unifies urban spaces through the repetitive use of columns and arches. Additionally, it is a visual threshold between urban space and architectural façade-creating a layer of depth and social activity in between its columns and adding spatial richness to the urban street or plaza. Functionally, it serves to protect people from the harsh tropical sun by casting shadows onto the façade and funneling breezes from building to building. It also funnels human activity through multiple buildings by providing continuous paths throughout the city.

Historically, portales have a profound connection to colonial architecture in Cuba. Brought to Cuba from northern Spain (during the early colonial period), they were prescribed by local building codes for any architecture within public plazas where they served to create pleasant public spaces suitable for selling goods. Additionally, their columns identified buildings of importance in the city by recalling the beauty and grandeur of Spain's colonial architecture. Eventually, they became the single most identifying element of Havana's urban landscape and led to its reference as "the city of columns."

During the $18^{\text {th }}$ and $19^{\text {th }}$ centuries, building codes and ordinances in Havana prescribed portales in major urban streets, particularly within the zone beyond the city walls known as la zona extramuros.

\footnotetext{
${ }^{2}$ The term "city of columns" was coined by Alejo Carpentier in his book La Ciudad de las Columnas.

${ }^{3}$ Referenced from the book Arquitectura De La Casa Cubana, pg. 53 by José Ramón Soraluce Blond, ed. (Coruña: Universidade Da Corufia, 2001). Translated from Spanish to English by author.
}

Adapting Neo-Classical principles, their columns and arches were monumental in scale and created unified urban façades running for blocks at a time. They also maintained a sense of urban order in the city. As María Victoria Zardoya Loureda points out regarding Neo-Classical urban design in Havana:

A search for beauty, harmony, decorum, and adequate proportions was promoted. Neither independent façades of buildings, nor a reduced number of them were considered, bu rather the unitarian image of a much larger whole, in a design unified and integrated with the urban fabric ${ }^{4}$

During the transformation of open space typologies in Havana, namely, the transition from the old city's rectangular plazas to the linear open spaces of the new city's paseos, portales served as common elements of urban connection. Thus, aside from being thresholds at an architectural scale in their relationship to a single building and a plaza, they are also transitional spaces at an urban scale activating the street life of the city.

\section{The Zaguán}

The zaguán is the transitional space between the portal and the public spaces of the house. It serves as a central node to distribute people to the public areas of the house or through the galeria into the open-air patio. Often it became a literal extension of the street, bringing carriages into the patio for business purposes through monumental doors called portadas.
${ }^{4}$ Quoted from the book Arquitectura De La Casa Cubana, pg. 53 by José Ramón Soraluce Blond, ed. (Coruña: Universidade Da Corufá, 2001). Translated from Spanish to English by author. 


\section{The Galeria (Gallery)}

The galeria is both a threshold and a transitional space between the interior of the house and the open-air patio. Conceived as more than mere circulation space, it is generally a semi-public / semiprivate zone that serves as an extension of family activities within the house such as those taking place in the living room, dinning room, or bedroom. Likewise, it is also extends the public activities of the patio into the interior of the house. It is, in essence, a portal at the periphery of the open-air patio that serves as a programmatically undefined in-between space between public and private zones.

Like the portal, the galeria is also a visual threshold between the communal space of the patio and the architectural façade of the house, activating the patio 's periphery through a layer of columns and arches. Additionally, it is a programmatic connector providing an open-air path between interior spaces while protecting people from heat by casting shadows and funneling breezes.

The galeria also serves as an extension of the private bedrooms on upper levels, acting as an interior balcony that wraps around the patio. It draws visual connections between private bedrooms and the public patio. Furthermore, the juxtaposition of lower and upper level galeria spaces accentuates the otherwise simple façade with a vertical layer of semi-public / semi-private activities, contributing to a rich interconnection of functions.

The Patio

The patio came to Cuba from Spain and its Islamic influences during the early colonial era (1512-1762). A transitional space between public and private program, the patio is the main feature of the colonial Cuban house. Typically, it is a square, open-air central space surrounded by the galeria and accessed through the zaguán from the street or plaza. In times past, the patio served to separate family activities from servant areas. It organizes hierarchical transitions of space, generally from public (entry) to private (traspatio). ${ }^{5}$ It is, in essence, a smaller, private version of an urban plaza.

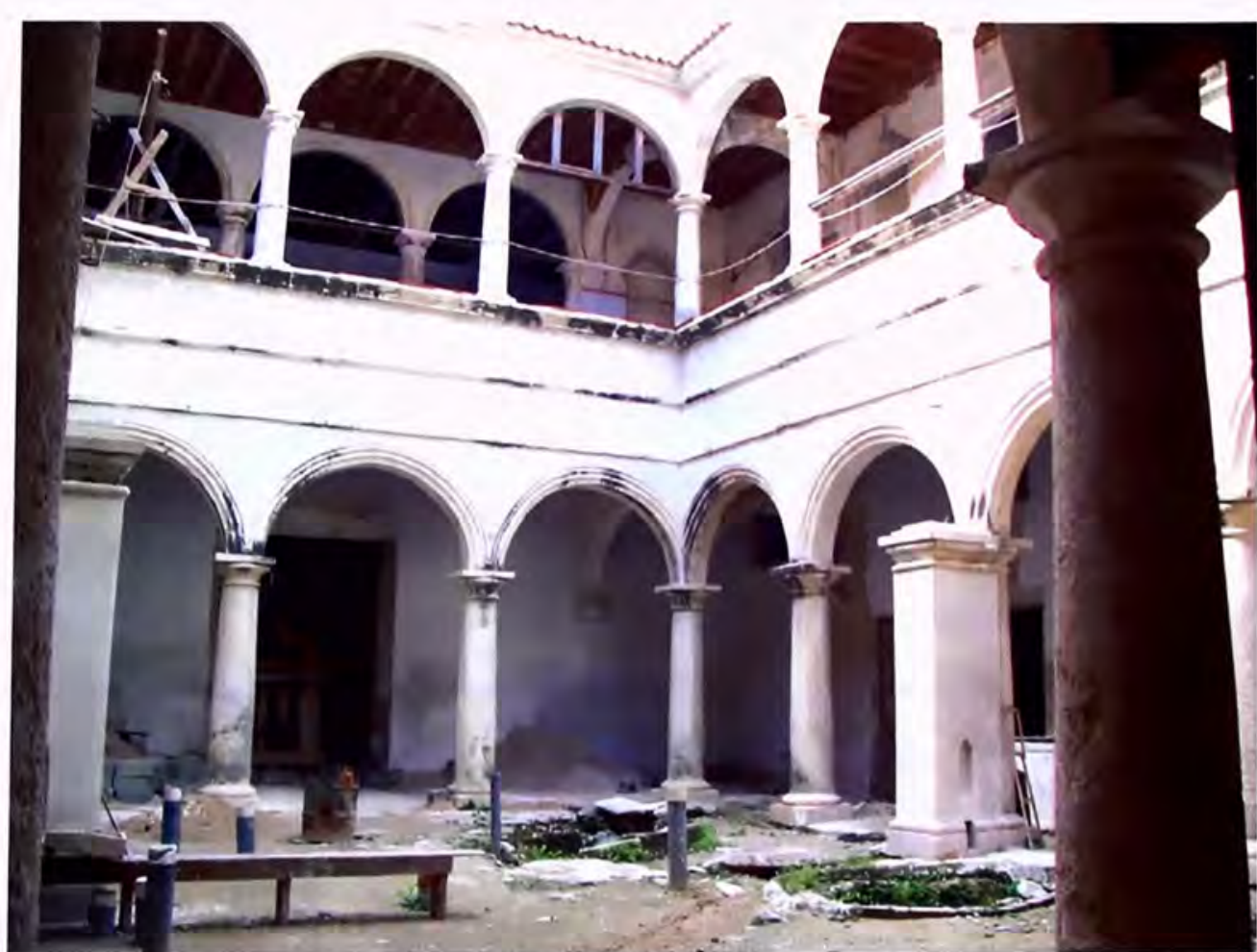

Figure 4 Photograph showing lower and upper level galeria spaces. Notice how the depth created by the layering of framed spaces in between the columns and arches (upper right) draws the eye inward. Source: By author (2004) 
As a transitional space, the patio serves as the center of family activity and. like the galeria, an in-between space that is multi-functional in nature. Also, while it can be considered an extension of the street. it is separate enough to provide the family with peace and tranquility not found in the animated urban plaza. ${ }^{6}$ Despite differences in scale and use however, the interior patio and the urban plaza share similar qualities. Both are multi-functional common spaces of interaction enclosed by a layer of transitional space at their periphery.

Functionally, the patio serves as a climatic pocket that facilitates the circulation of air and protects people from Havana's intense heat by allowing breezes to flow into the interior spaces. In doing so, the interior becomes integrated with Havana's tropical climate. It also allows a large part of the interior to be flooded with natural light. Thus, it serves as an ecological response to Havana's tropical climate-maximizing Havana's desirable climatic elements such as air and light while filtering out undesirable ones, such as heat, humidity, and torrential rain.

Throughout Havana's history, the patio, along with the colonial Cuban house, has undergone several transformations. By the end of the $18^{\text {th }}$ century, a number of colonial Cuban houses were remolded and transformed into apartments still known today as casas de vecindad. As a result, the patio became a public space used by multiple families as opposed to a private space used by a single family.

By the end of the $19^{\text {th }}$ and into the $20^{\text {th }}$ century, new distributions of property into smaller, narrower lots altered the patio typology by enclosing it within c-shaped buildings-replacing an entire layer of architecture with the back of adjacent buildings (Figure 5).

During the late 1920s the patio began to lose its significance in the eyes of modern architects and developers. Some opted for standardized building types that had little to do with Havana's urban and architectural context. As stated in the essay Life and Death of the C'ourtyard House: Migration Metissage and Assassination of a Typology:

Instead of learning from history, the leading figures of the finance and real estate markets asked their architects to follow the recipes offered by the pioneers of the Style Moderne. The architects discovered at that in those times, success was not related to respect for culture but to the application of a formula that had very little to do with collective memory and the ecological response to the housing problem.

\section{The Traspatio}

The iraspatio, usually located towards the back of the house and separated from the main patio, was a secondary patio designated specifically for servants and their domestic occupations. Often overlooked by a dinning room, the traspatio served as a secondary communal space for the family. It was typically accessed through a galeria and is a transitional space between the public and private zones of the lower floor. The difference, however, is that while the patio is revealed as soon as one walks through the zaguan, the traspatio is hidden behind a layer of service oriented program or a secondary galeria, completing a system of layered spaces veering from public to private.

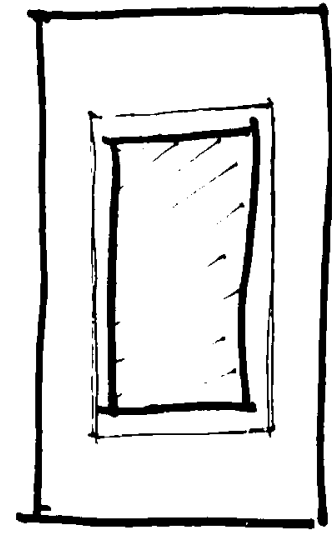

Figure 5 Patio typology study. By the beginning of the $20^{\text {th }}$ century, patios began to be enclosed within c-shaped buildings. Source: By author (2005) 


\section{The Plazas of Old Havana: The Urban Façade}

Urban façades are the faces of the city. They give the city character, identity, and a sense of place. In historic cities, their details express layers of social, cultural, architectural, and urban historyengraving the memory of times past on their surfaces. When proposing a contemporary design project in a historic urban fabric. careful consideration must be given to its urban and architectural character expressed through its urban façades.

In Old Havana, the urban façade expresses almost 500 years of cultural and architectural history. My project reinterprets specific visual, social, and functional qualities of Old Havana's urban façades, with a particular emphasis on the Plaza Vieja. In doing so, my design contributes to Old Havana's architectural and urban character without cosmetic imitation. Specifically, my analysis focuses on three aspects of urban façades in Old Havana:

1. The façade as part of an urban composition (visual)

2. The façade as a generator of social activity (social)

3. The façade as a climatic filter (functional)

\section{The Façade as a Part of an Urban Composition: The Plaza Vieja}

Architects in Old Havana integrated architectural façades harmoniously into the urban environment in order to maintain urban order and a unified sense of place. Particularly, within Old Havana's urban plazas, building façades are uniform and rhythmic. They were carefully composed as parts of an urban ensemble.

Mandated by $18^{\text {th }}$ and $19^{\text {th }}$ century building codes, architects in Old Havana were required to comply with strict guidelines regarding the design of urban façades in the city's plazas. The codes regulated floor, cornice, frieze and balcony heights while offering architects relative flexibility in the modulation of columns and pilasters-as long as they were designed using classical proportions.
Despite the flexibility, however, architects typically adhered to solutions of past centuries, which responded proportionately to Old Havana's narrow and compact lots.

In an effort to maintain urban beauty and a unified pedestrian scale throughout the city, architects in Old Havana-moved by a love for their city—not only complied with these codes, but regarded them highly as design tools towards an artistic and methodical approach to urban architecture. In 1915 , Cuban architect Hilario del Castillo wrote:

The distribution is the art of dividing with order and symmetry all the parts of a public building ... its decoration is found in its symmetry and regularity. It's making sure that all of the openings of doors and windows are opened at the same height and aplomb, that the friezes and cornices form long lines without interruption; that the pilasters, columns, jambs and lintels, and other decorations that enrich the urban façade of the building repeat identically in the other, that it may always be an opening that forms in the middle or center of the building and never residual or just any other aperture.

Castillo's words adequately describe the urban character the Plaza Vieja.

As Old Havana's second oldest plaza, the Plaza Vieja's building façades display the evolution of over four centuries of urban architecture. Throughout this time its urban composition has remained intact as if designed by a single architect. Through symmetry, modulation, carefully planned alignments, and scale the Plaza Vieja's building façades display an urban uniformity that has defined Old Havana's public spaces for centuries. Regarding the Plaza Vieja's urban character Carlos Venegas Fornías writes:

The uniformity of the façades with its rhythms of arches and columns, and the versatility of the activities realized in its open space, conferred (upon the plaza) a particular architectural dignity and a peculiar civil significance.

${ }^{7}$ Quoted from the book Arquitectura De La Casa Cubana, pg. 64 by José Ramón Soraluce Blond, ed. (Coruf́a: Universidade Da Corufa, 2001). Translated from Spanish to English by author.

${ }^{8}$ Quoted from the book Plazas de Intramuro, pg 88 by Carlos Venegas Fornías (La Habana: Consejo Nacional de Patrimonio Cultural, 2003). Translated from Spanish to English by author. Parentheses added by author. 


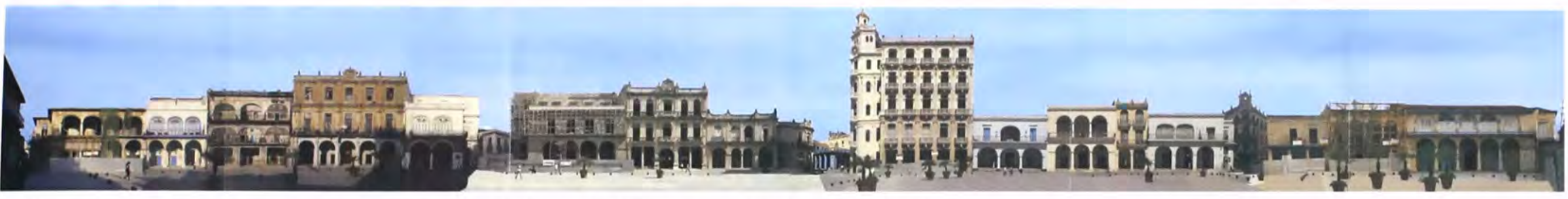

"In Havana, the facade is a painting in concrete. It is composed. You can feel the architects or builders thinking of all the parts. The 'faces' of the street compete for the status of most beautiful."-Glenn Weiss, The Architecture of Havana 
Using classical proportions, the majority of the façades are bi-laterally symmetrical, maintaining a distinct compositional order within themselves and in their relationship to one another. At times it is difficult to distinguish where one façade ends and the other begins. Some are barely separated by ultrathin vertical shadow lines cast in between them. Others blend into each other virtually seamlesslydistinguished only by a slight difference in tone or height.

Their overhanging balconies and cornices extend horizontally from building to building, at times shifting vertically, but always demonstrating careful compositional articulation through their alignments at the edge or center of adjacent openings-harmoniously stitching the plaza's façade together. Similarly, the columns and arches of their porfales are repetitive. Modulated by vertical bays, these elements continue from building to building virtually seamlessly, further blurring the physical boundaries between their façades.

Another important factor contributing to their harmonious integration is scale. With one exception (Hotel Cueto), the façades maintain a unified pedestrian scale throughout the plaza in terms of height and overall proportion. Aside from being designed methodically using modulation, planned alignments, and scale however, the Plaza Vieja's façades also embody a visual composition of light and shadow.

Specifically, the façades embody a play of light and shadow through an articulation of depth. The portales on the ground floor, for example, are juxtaposed with deep-set openings on the upper floors, giving the façades fluctuating depths. This is further enhanced by deep upper-level portales and windows as well as protruding balconies. Each having different depths, these elements manipulate light and shadow at different intensities throughout the day. When articulated throughout the plaza, the multiple layers of light and shadow give it a warm sense of enclosure and engage people into visual dialog with its façade.

Time has introduced another aspect of the plaza's building façades that were not intentionally designed; decay. Age contributes to the beauty of the Plaza Vieja's colonial façades. Their old, wornout surfaces add a new layer of depth and visual composition, enhancing the plaza's colonial charm.

\section{The Façade as a Generator of Social Activity: Portales and Balconies}

The portales and balconies of these façades manifest a push / pull dialog between public (lower) space and private (upper) space. While the portal pulls the public space of the plaza into the façade in between its columns and arches, the balcony pushes the private space of the building through the facade into the urban plaza, activating the façade with multiple layers of depth and human activity. This interaction between public and private space makes the urban façade a generator of social activity and interaction-allowing people to see and be seen. Additionally, portales and balconies give the solid colonial wall a permeable quality that makes it perceptually transparent, interactive, and interchangeable.

The ground level portion of the façade is composed of a recessed solid wall superimposed with a layer of columns and arches. The space in between the two layers, a portal always in shadow, serves as a stage, continually altering the façade as people interact within it. The dialog between light and shadow in the portal causes people to appear partially silhouetted at different times of the day-imposing a level 

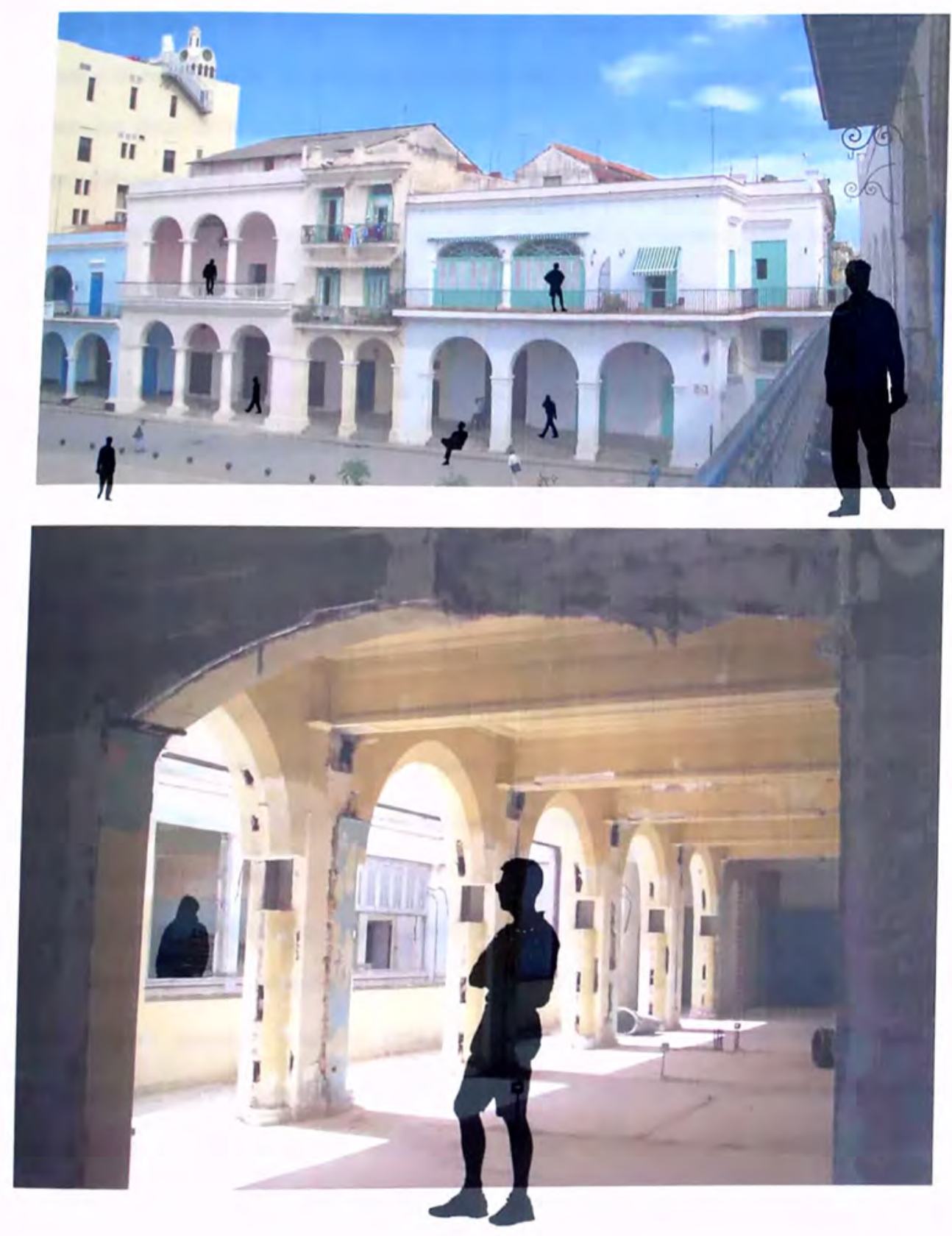

Figure 7 Analytical collages of the Plaza Vieja and a colonial building currently undergoing restoration. Portales and balconies frame and juxtapose various activities at different heights and distances, activating the public space of the plaza through multiple layers of social activity. Source: By author (2005) 
of theatricality to the façade by perceptually superimposing reality with abstraction. From a distance one also engages in a visual dialog between the façade's massive columns and the residual space in between them (solid vs. void), using depth and transparency to connect one visually with the urban activities taking place behind them.

On the upper floors, balconies protrude outward as if a layer of façade had been pulled apart from the wall. Their railings are detailed intricately out of wood or iron and are artfully executed. Like the portal, there is a visual dialog (at a much smaller scale) between the thin railings and the residual space in between them-revealing the activities taking place in between the two layers and always maintaining a visual connection between the upper floors and the plaza. Additionally, balconies also serve as an elevated stage from which private activities can be seen in the urban plaza and vice versa.

The juxtaposition of public and private activities within the urban façade animates the urban plaza. From both the urban plaza and its buildings, portales and balconies frame multiple views and activities at different angles, heights, and distances, allowing people to experience multiple scenes simultaneously; a private conversation between two family members, children playing a game of soccer, a group of men discussing baseball, or a game of dominos. These events take place from multiple vantage points - far, near, high, low, and oblique - engaging one through multiple layers of space from both the plaza and the façade.

\section{The Façade as a Climatic Filter: Persianas and Vitrales}

Functionally, the urban façade responds well to Havana's tropical climate. By using thick solid walls, deep-set openings, projected balconies and eaves, natural materials and finishes, louvers (persianas), and stained glass windows (vitrales) colonial façades use literal as well as perceptual depth (colors, transparencies, and finishes) in response to Havana's intense heat and humidity. Because they

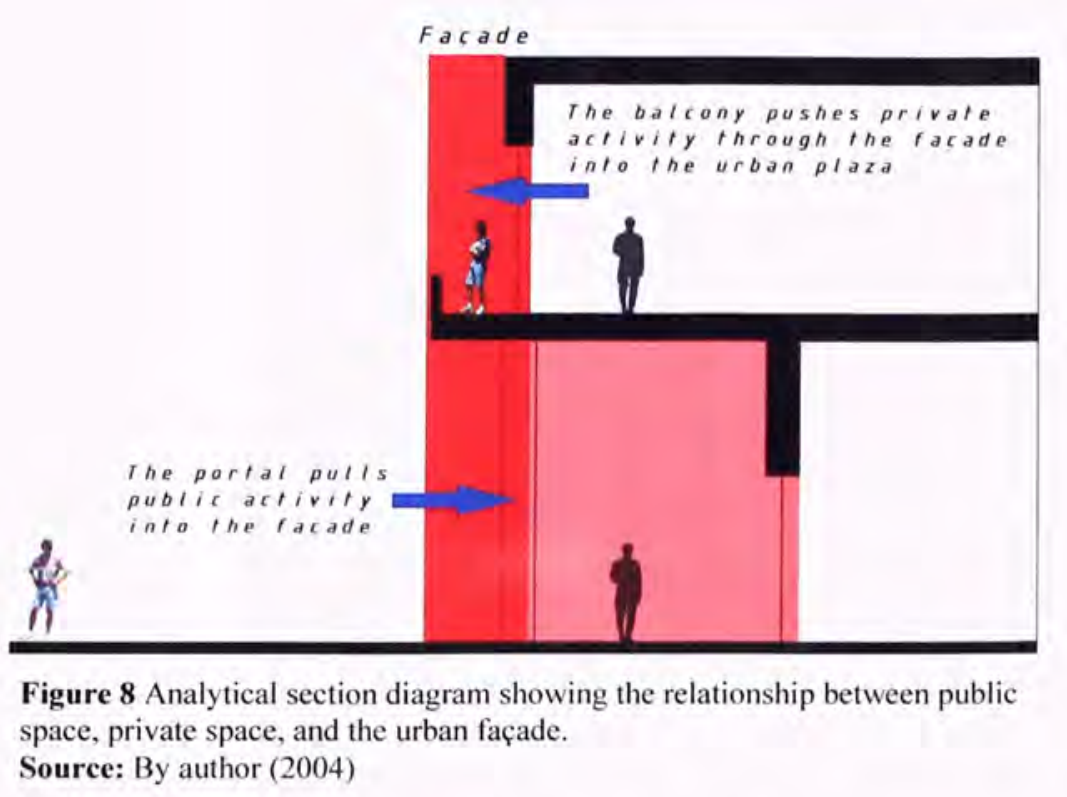

affect both sides of the façade through filtered light, views, and activities, this thesis specifically investigates the role of persianas and vitrales in the colonial urban façade.

Persianas (Louvers)

Coming to Cuba from the French-Louisianan-Haitian line, the use of persianas in Old Havana began towards the end of the $18^{\text {th }}$ century. By the time they reached Old Havana they had evolved from a fixed element to an adjustable one in order to respond to multiple climatic conditions. Stylistically, they evolved to produce two different types, the French version and the Miami version known as Persiana de Miami. According to Eugenio Batista:

What we call French has, as an entirely Cuban innovation, a glass shutter which permits it to be left open for the passage of light in the case of rain, although without this additional feature it has been used in exactly the same way in North America. The "Miami" type is not a Floridian invention as its name may imply."

\footnotetext{
${ }^{9}$ Quoted from the essay The Cuban House: Patios, Portales y Persianas by Eugenio Batista (Artes Plasticas, Vol. 2, 1960).
} Translated from Spanish to English by Raúl Garcia. 
Different from the custom-made hardwood version used in Cuba, the Persiana de Miami is a prefabricated, adjustable glass-louvered window popular in South Florida since the 1930s.

Using literal depth, persianas are ultimately used to control the intensity and direction of sunlight and wind penetrating the façade into the interior. Visually, they add depth to both the façade and interior spaces by fragmenting views and light in between their inclined slats of wood, using light and shadow to accentuate a play between solid and void. As a deep (both visually and literally) climatic filter, persianas integrate interior spaces, the urban façade, and the natural environment.

Vitrales (Stained glass windows)

Originating from Gothic architecture $\left(12^{\text {th }}-16^{\text {th }}\right.$ century), vitrales began to emerge in Old Havana's colonial architecture during the $18^{\text {th }}$ century in the form of intricately designed stained glass windows. Typically, they were placed above persianas in order to complement their effect on natural light. The most common design is the mediopunto, which radiates symmetrically from a central point culminating in a half circle. The drawings etched on their colored glass recall Havana's tropical landscape; a sun, a colorful flower, or other tropical vegetation. Historically, they served a two-fold purpose:

1. To beautify the architecture through the use of color, natural light, and shadow

2. To protect the interior against wind, rain and heat

Color has long been a part of Cuban culture as is evident in Cuban painting, sculpture, music, theater, and architecture. As a cultural inclination, the colors used in vitrales are strong, vibrant, and responsive to Havana's intense light by complementing its natural colors-integrating the urban façade harmoniously with its natural environment. Red and violet, for example, complement Havana's warm tropical soils and recall its long hot summers. Blue and green complement the ocean's waters. And yellow complements the strong Caribbean sun. These colors were usually combined in pairs with occasional splashes of snow white. Interestingly, the colors used were, for the most part, primary, offering the urban façade a plastic quality that both complements and contrasts Havana's tropical color palette

Using perceptual depth, vitrales add a layer of color and refracted light to the interior. It also absorbs heat and maintains the interior cool. In essence, it acts as a layered threshold (conceptually, color superimposed on glass) that transforms natural light as it reaches the interior. From the exterior, their brightness fluctuates throughout the day as the intensity of the sun changes - complementing the fragmented views into the interior offered by persianas with an interplay of color, light, and shadow. 


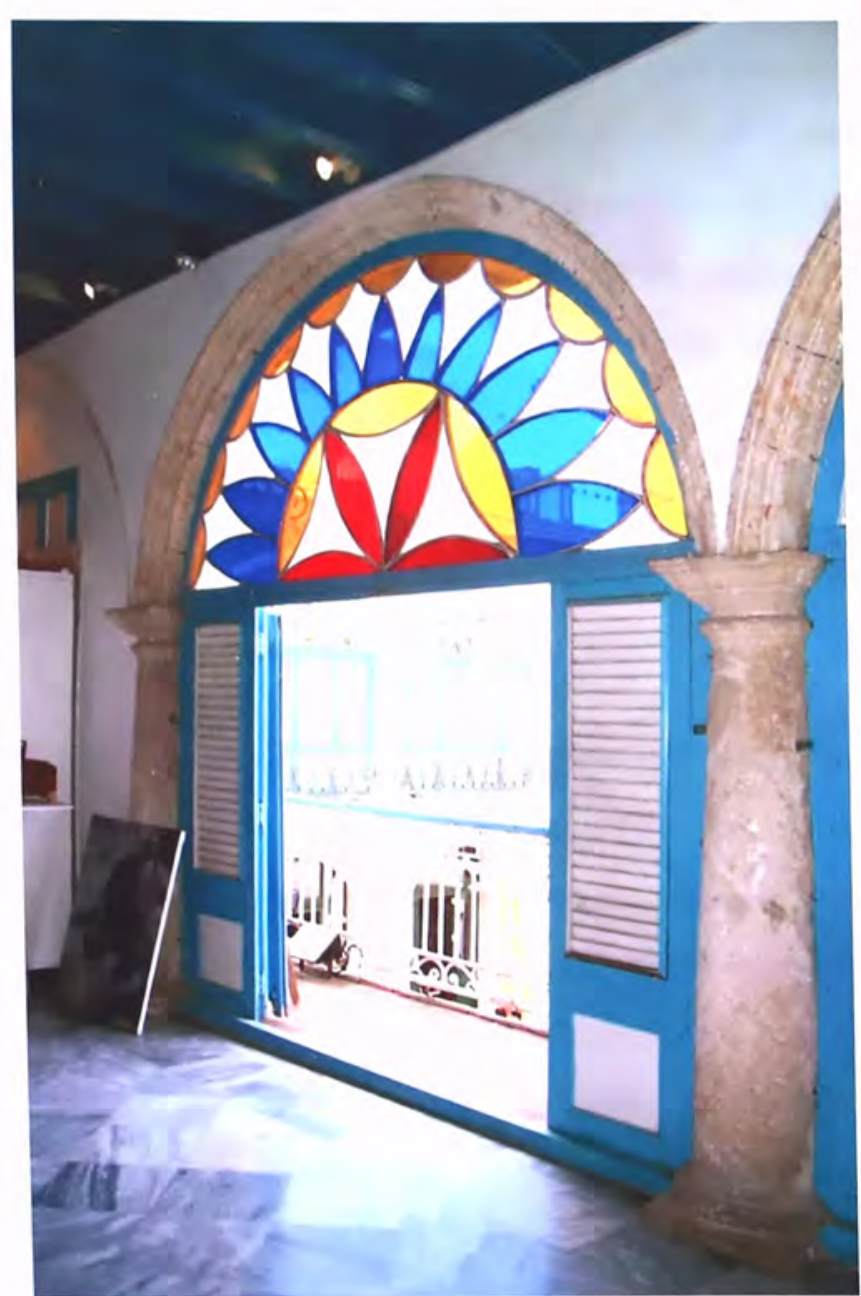

Figure 9 Photograph showing a mediopunto vitral and persianas. Notice the similarities between the design of the vitral and that of a flower.

Source: Photograph taken by author (2004)

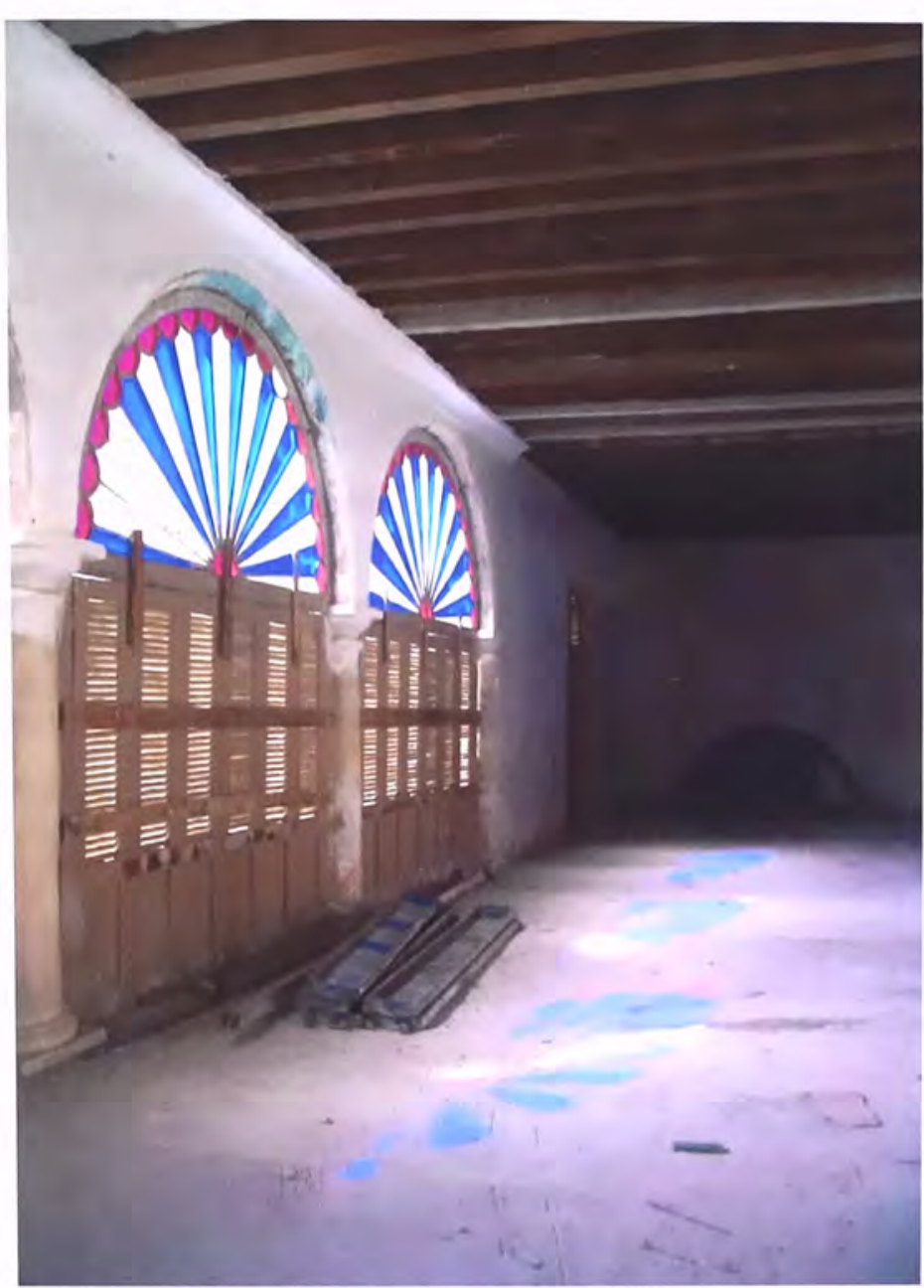

Figure 10 Photograph showing the interplay of color and

light as it penetrates the interior. Notice the color on the

floor.

Source: Photograph taken by author (2004) 
In the mid-twentieth century, architects in Havana were engaged in an intense debate concerning the role of Cuba's colonial architecture in their work. Opinions were split. Conservatives opted for an uncompromisingly traditional aesthetic while others rebelliously advocated a totally new style that acknowledged a clean break with the past. Still, there were some who searched for a convergence of the two extremes and opted for a modern architecture that would harmonize with the past by reinterpreting the functional, spatial, and aesthetic aspects of Cuba's colonial architecture while embracing European Modernism. These architects, having reached their peak in the $1950 \mathrm{~s}$, engaged a synthesis between old and new in their work and contributed to the most influential development in the quest for a national identity in Cuban architecture.

Cuba, having been liberated from Spain in 1902, was anxious to establish itself as an independent nation having its own cultural and national identity. As a result, architecture in Havana went through an "avalanche of styles" 10 in the first quarter of the $20^{\text {th }}$ century in search for a distinctly Cuban language. Among these was an eclectic period in which architects stitched together stylistic elements of their colonial architecture with those of international architecture in an attempt to cosmetically reinterpret Havana's cultural and architectural history. There was also a superficial NeoColonial Revivalist movement which overlooked the environmental sensitivity of Cuba's colonial architecture. Simultaneously, Havana saw the up-rise of Art Nouveau, Art Deco, and Streamline Moderne-all primarily concerned with stylistic issues.

In 1926, European Modernism was introduced in Havana when the Cuban architectural magazine El Arquitecto published an article supporting the ideas of Le Corbusier and the machine

${ }^{10}$ Referenced from the book The Havana Guide: Modern Architecture 1925-1965 by Eduardo Luis Rodriguez (New York: Princeton Architectural Press, 2000). aesthetic. Amidst intense debate and controversy, however, it was not long before the editors of $E l$ Arquitecto reversed their stance. A short time later they published several articles expressing their opposition towards the Modern Movement."

In 1932, the magazine Arguitectura y Artes Decorativas devoted an entire issue to Modern Art. In it conservative architects were criticized for clinging to the past and were encouraged to embrace Modernism as the new model of architectural and urban expression. One article relates that:

To stop, to stagnate, when all around us the world forges ahead without pause, is to retreat... The vanguard or the rearguard, progression or regression; these are the only alternatives open to us.

By the 1940s and 50s, theoretical debates between tradition and modernity made their transition from the pages of architectural journals into architectural practice and education in Havana. In 1947, the infamous quema de los Vigñola took place at the University of Havana in which a group of architecture students—namely Frank Martínez, Ricardo Porro, Rene Calvache, Isidro Cordovés, Joaquín Cristófol, German Hevia, and Nicolás Quintana-ritualistically burned the Vigñola Treatise in the library's courtyard in an act of youthful rebellion aimed at expressing their allegiance to Modernism and their discontentment with the classically inspired academic curriculum. Architect-Urbanist Nicolás Quintana relates based on his experience

In December of 1947 a specific event took place known as the burning of the Vigñola Everything occurred around midday when a small group of students were debating in the corridors facing the interior courtyard of the school, on the same floor as the library. The debate was based on the futility of the efforts to force a change of focus in the teaching of

"For a more comprehensive overview of Modernism in Havana consult the book The Havana Guide: Modern Architecture 1925-1965 by Eduardo Luis Rodriguez. The introduction in particular focuses on the intellectual environment surrounding the Modern Movement in Havana between the 1930s and the 1950s.

${ }^{12}$ Quoted from the book The Havana Guide: Modern Architecture 1925-1965, pg. 11 by Eduardo Luis Rodriguez (New York: Princeton Architectural Press, 2000). 
architecture. Suddenly, moved by an inner impulse, spontaneous and unstoppable, we came to the conclusion that there needed to be an act of immediate rebellion that would draw the attention of the faculty and the people in reference to this problem. We decided to shake the tree so that, even though symbolically, the rotten fruit of Neo-Classicism would fall to the ground and be substituted by contemporary and progressive focuses.

He goes on further to say:

We selected for the burning the "Tract of the Five Orders" from Jacopo Vigñola, a book which we respected as an expression of culture, but were opposed to as a typical example of an instrument utilized for the rigid, unimaginative implementation of a plan of study which dwarfed the organic growth of Cuban architecture.

After this event and a visit to the University of Havana by Walter Gropius, the faculty loosened their rigid curriculum to reflect a more progressive teaching style.

Prior to these events. however, there were already some who publicly expressed the need for Regional Modernism in Havana, In 1934, Cuban architect Leonardo Morales emphasized the ideal qualities of the Cuban house as part of his reception speech for his induction into the National Academy of Arts and Letters (Academia Nacional de Artes y Letras). He based his speech on a passage from Le Corbusier's Towards a New Architecture. As University of Wisconsin professor Narciso G. Menocal states:

According to Morales, Le Corbusier's definitions were apposite to establish a tropical architecture. Yet, he also argued, the International Style should never be used in Cuba Large expanses of glass, thin walls unprotected from the sun by cantilevered eaves, and low ceilings were improper for the tropics, where summers may be ten months long.

\footnotetext{
${ }^{13}$ Quoted from the essay Arquitectura Cubana (1940-1960): La Generacion Del' 50 by Nicolás Quintana (Arquitectura
} Cuba, 1960). Translatcd from Spanish to English by author.

${ }^{14}$ Quoted from the article Lo Cubano in Cuban Architecture: 192 -1964 by Narciso G. Menocal (Herencia: El Rio de la Cultura Cubana, Vol.7, Summer 2001).
Morales clearly advocated modernity but also recognized the functional value of Cuba's colonial architecture, calling for a synthesis between the two.

\section{Dor Ia Modernización} de Ios Dlanes de Estudio

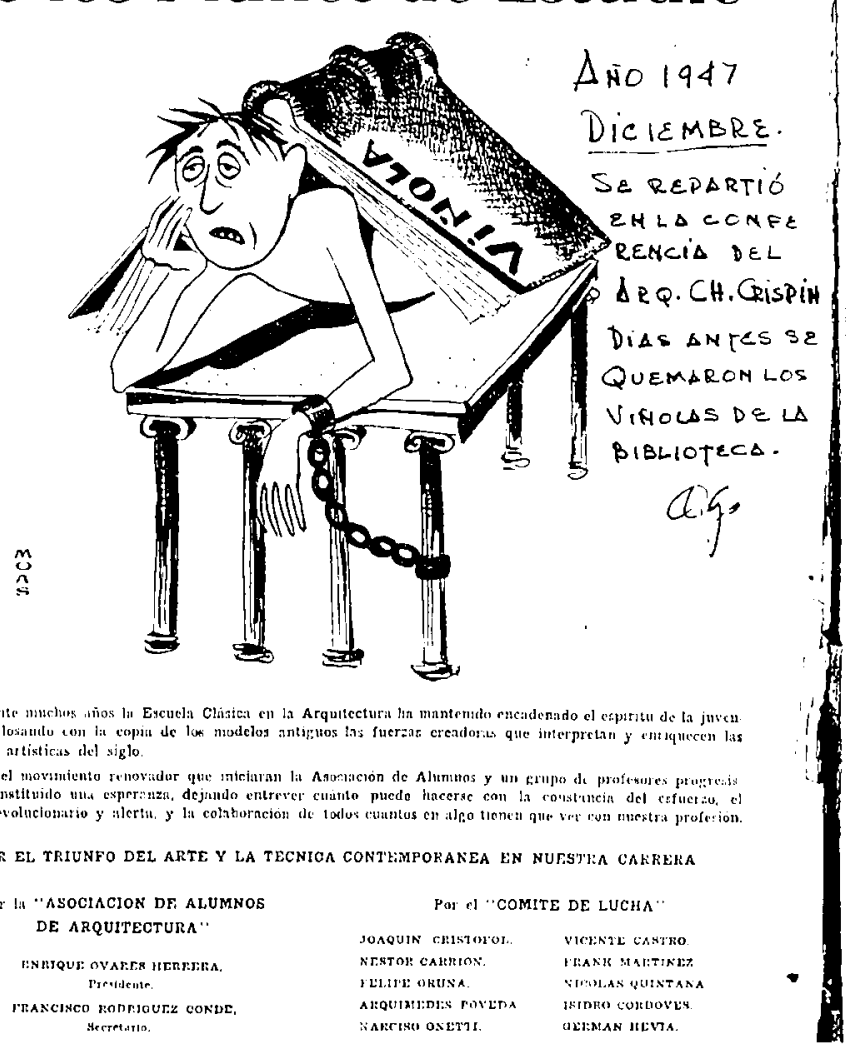

Figure 11 Flyer distributed several days before the quema de los Vigñola.

Source: Courtesy of Nicolás Quintana 


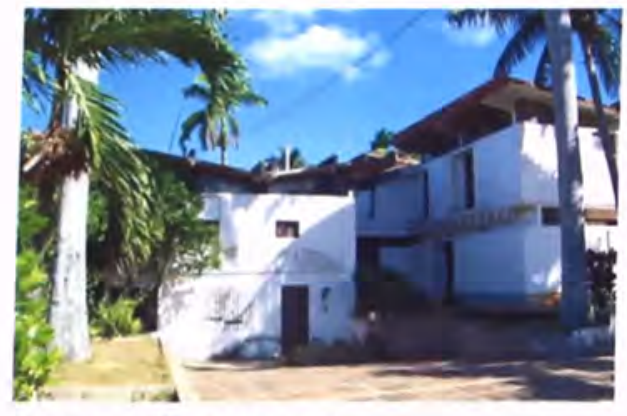

Mario Romañach

Ana Carolina Font House, 1959

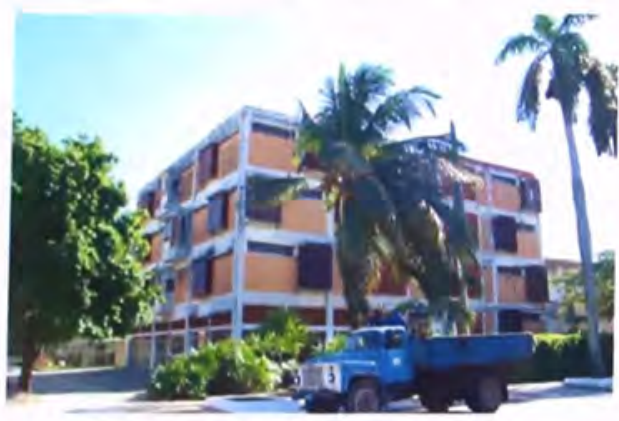

Mario Romañach

Apt. Blag. of Evangelina Aristigueta de Vidaña, 1956
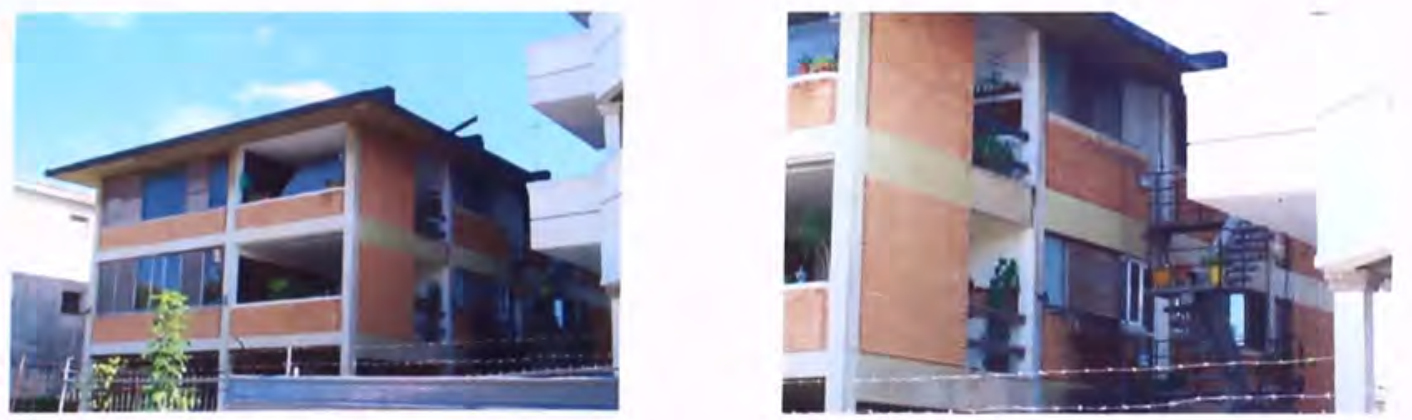

Mario Romañach

Apt. Bldg. of Josefina Odoardo, 1953

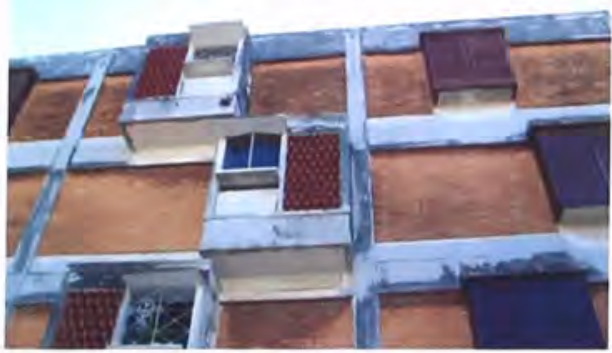

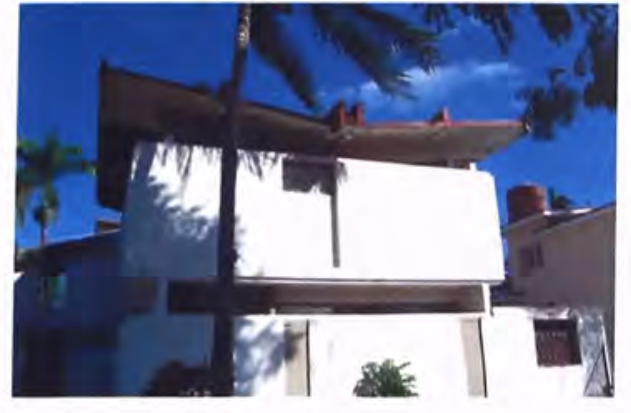
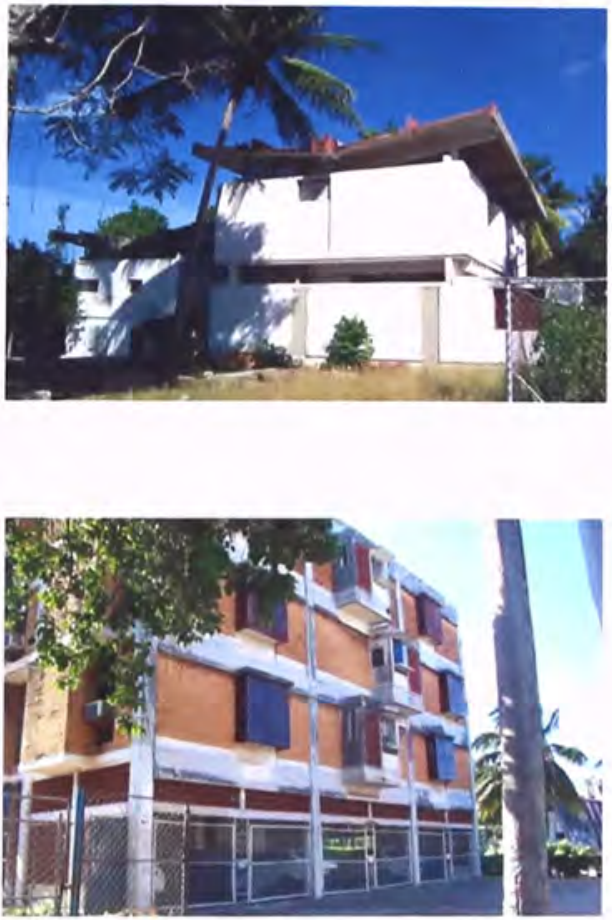

Figure 12 Architecture designed in Havana during the midtwentieth century by Mario Romañach. Note the juxtaposition of cold (concrete) and warm (red brick) materials and the use of traditional elements such as screens and louvers within the Modernist compositions. Romañach and others during the 1940s and 50s reinterpreted Cuba's colonial architecture, both spatially and functionally, in their work in order to maintain a sense of place while still embracing Modernism. This thesis proposes a creative leap between mid-twentieth century suburban architecture and $21^{\text {st }}$ century urban architecture in Havana.

Source: All photographs taken by author (2004) 

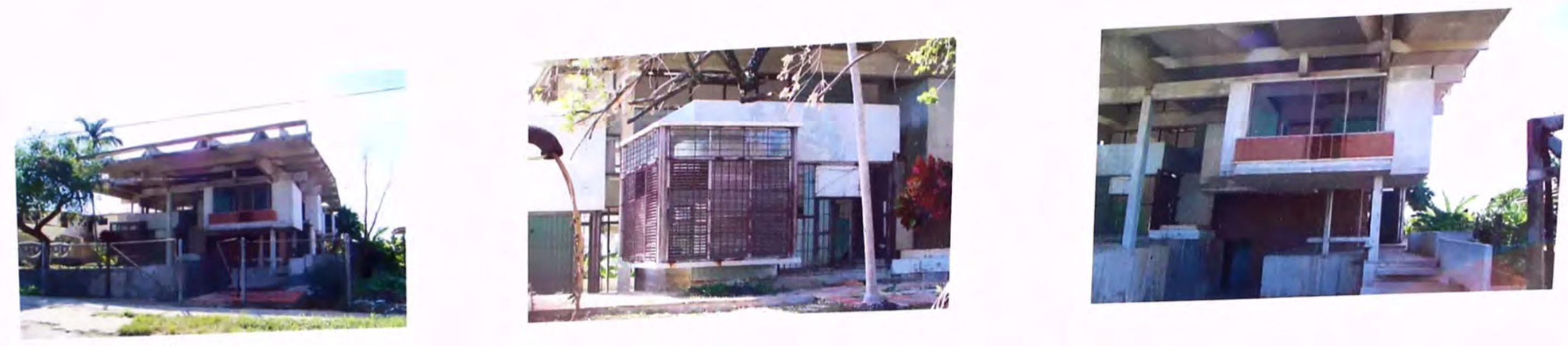

Humberto Alonso

Juan F. Lamas House, 1959
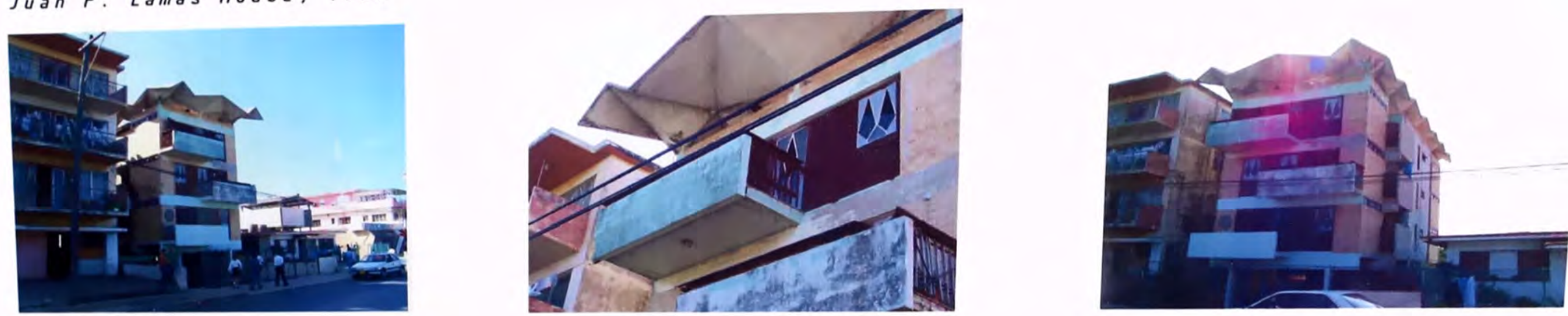

Apt. Bldg. of Reynaldo Cué, 1958
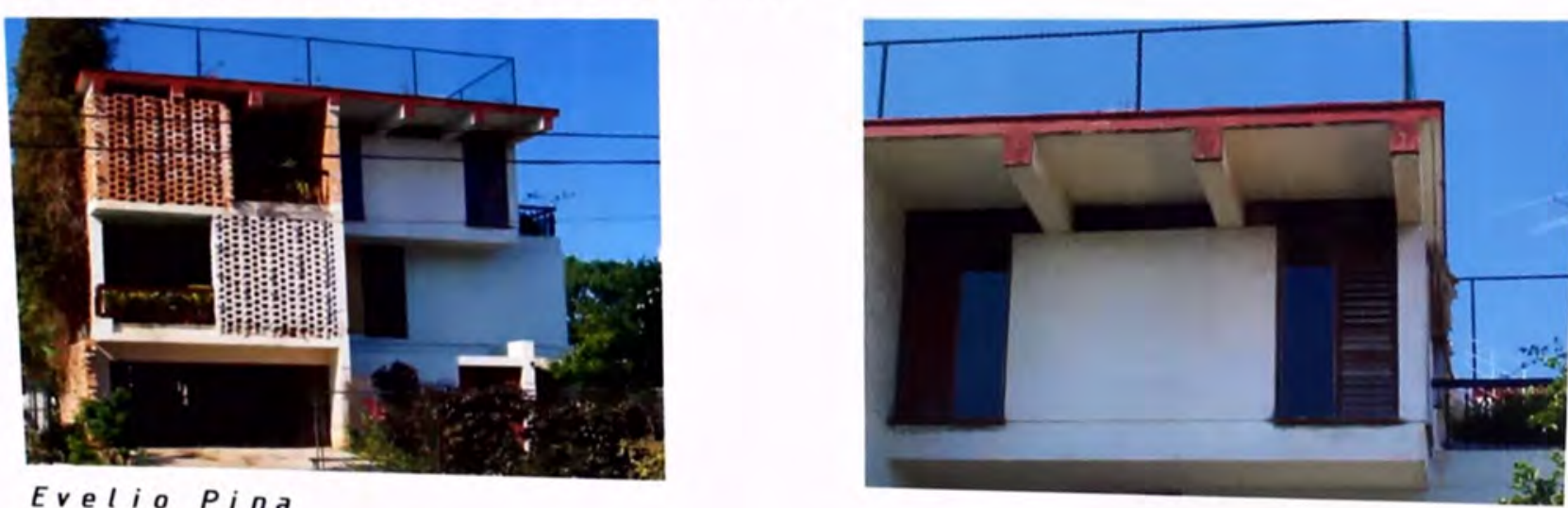

Evelio Pina

Apt. Bldg. of Orlando Cardenas, 1959

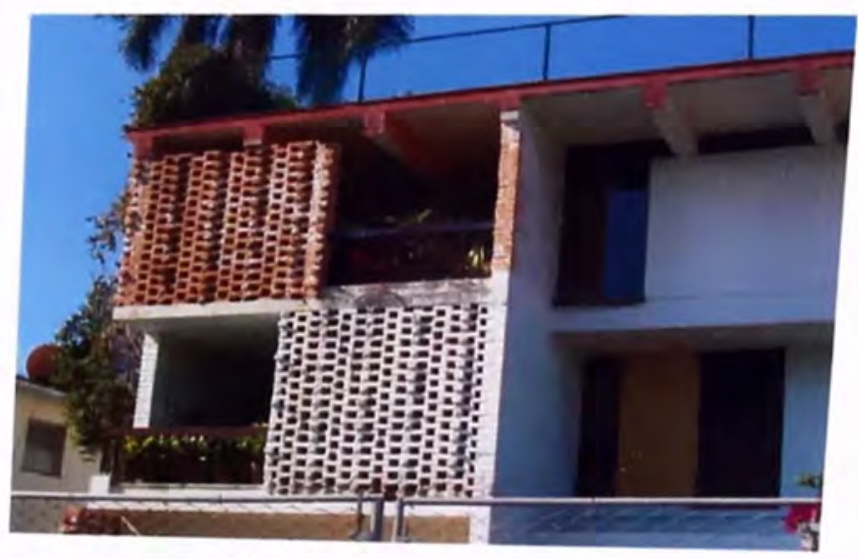

Figure 13 Mid-twentieth century architecture in Havana. Source: All photographs taken by author (2004) 

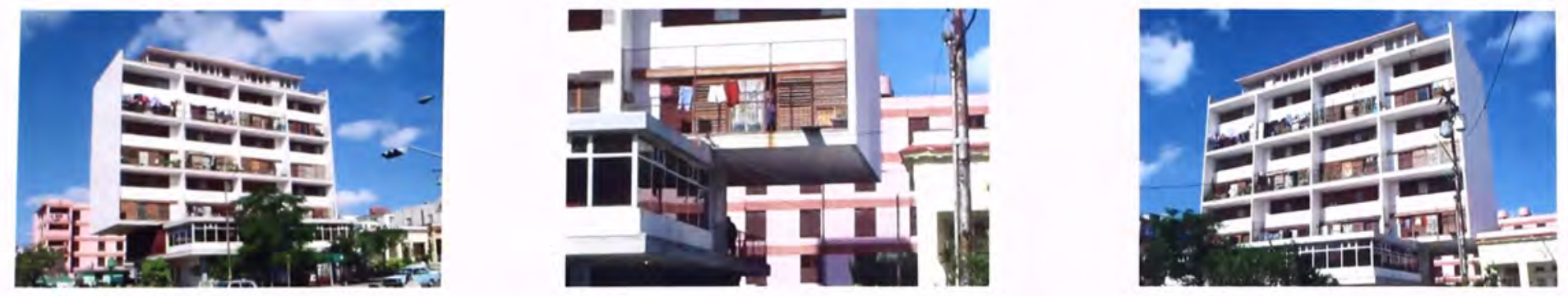

Antonio Quintana

Apt. Bldg. of Enriqueta Fernandez, 1950-1953/55
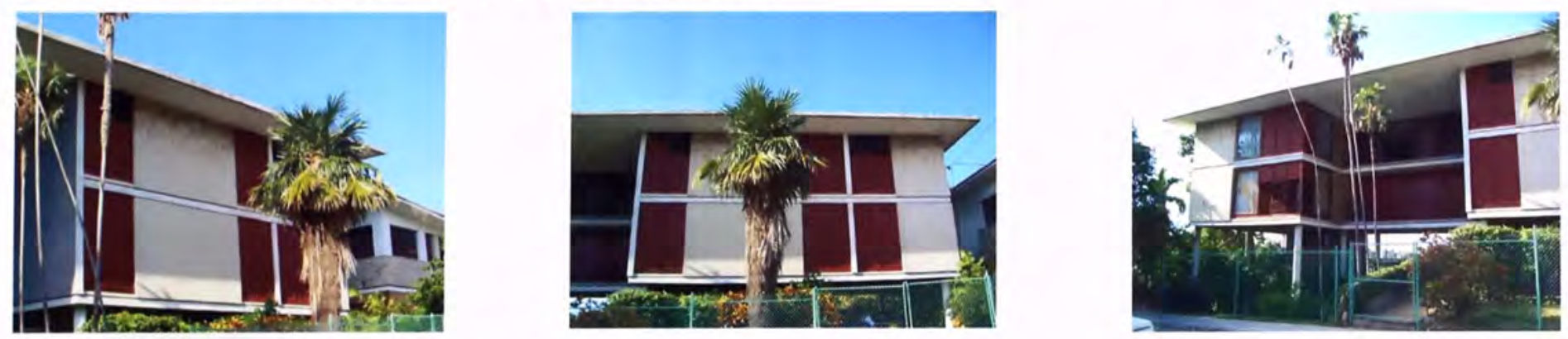

Frank Martinez

Apt. Bldg. of Isabel and Olga Pérez Farfante, 1955
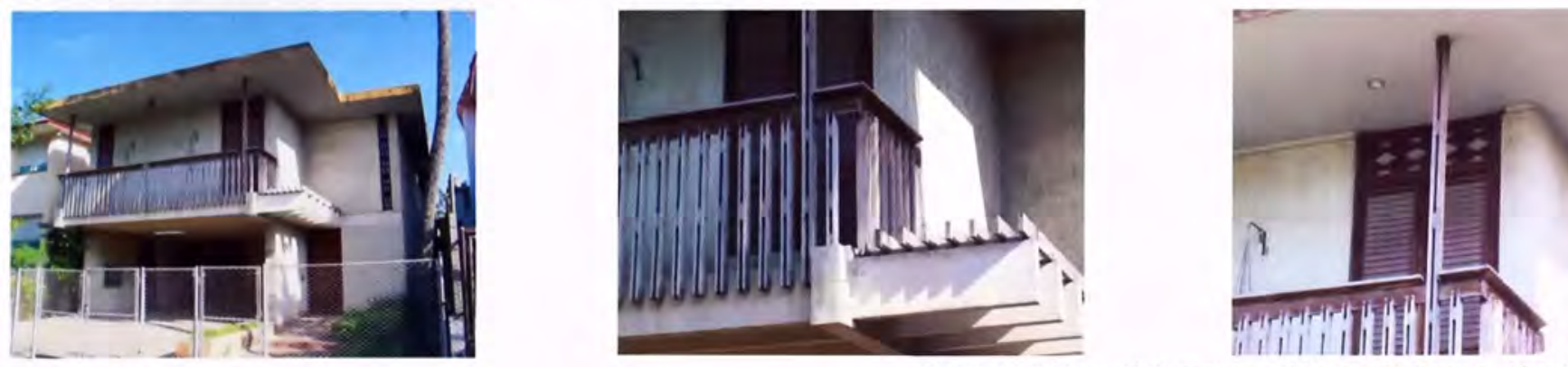

Figure 14 Mid-twentieth century architecture in Havana. Note the wood details and the use of louvers (persianas) and stained glass windows (vitrales).

Source: All photographs taken by author (2004) 
The first to apply Morales" thesis in his work was Eugenio Batista. whose architecture was based on a synthesis between colonial planning principles and a streamlined Modernism that was stripped of romantic connotations. In his essay, The Cuhan House: Patios, Portales, y Persianas, Batista identifies the three key elements of Cuba's colonial architecture as courtyards, porches, and louvers. He deemed these elements the ABC's of Cuban architecture and argued for their contemporary reinterpretation in the Cuban house-responding to Havana's current social and cultural context while staying true to its rich architectural history without cosmetic imitation. In his essay he claims that:

... we need not be led by this into the error of thinking that [by] simply copying our colonial houses we solve the problems of today. Along with the good lessons from which we should learn, there are others we should avoid. And it is not in these cases that the builders of these houses have failed, but that the conditions of the architectural problem have changed. If the natural environment remains practically the same, the social environment is different. If the climate and the landscape are unchanged, our customs are not. If the popular temperament is sensibly uniform, the rhythm of our lives has accelerated in a disconcerting way. ${ }^{15}$

Although the essay was written in 1960 , his thesis first became physically realized in 1939 with the design of the Eutimio Falla Bonet House.

Another influential figure was Cuban architect Mario Romañach. According to Cuban historian Eduardo Luis Rodriguez, Mario Romañach was "the architect possessing the greatest conceptual and formal merit of this period of abundant ideas." 16 His fusion of traditional Cuban architectural elements with a modern sensibility for volumetric articulation and environmental sensitivity made him one of the most respected Cuban architects among his peers. This thesis investigates one of his most important works- the José Noval Cueto House—as well as Batista's canonical Eutimio Falla Bonet House.

${ }^{15}$ Quoted from the essay The Cuban House: Patios, Portales y Persianas by Eugenio Batista (Artes Plasticas, Vol. 2, 1960). Quoted from the essay The Cuban House: Patios,
Trans from Spanish to English by Raúl Garcia.

${ }^{16}$ Quoted from the book The Havana Guide: Modern Architecture 1925-1965, pg. 27 by Eduardo Luis Rodriguez (New

York: Princeton Architectural Press, 2000). 


\section{CASE STUDIES}

3 Eugenio Batista - Eutimio Falla Bonet House, 1939

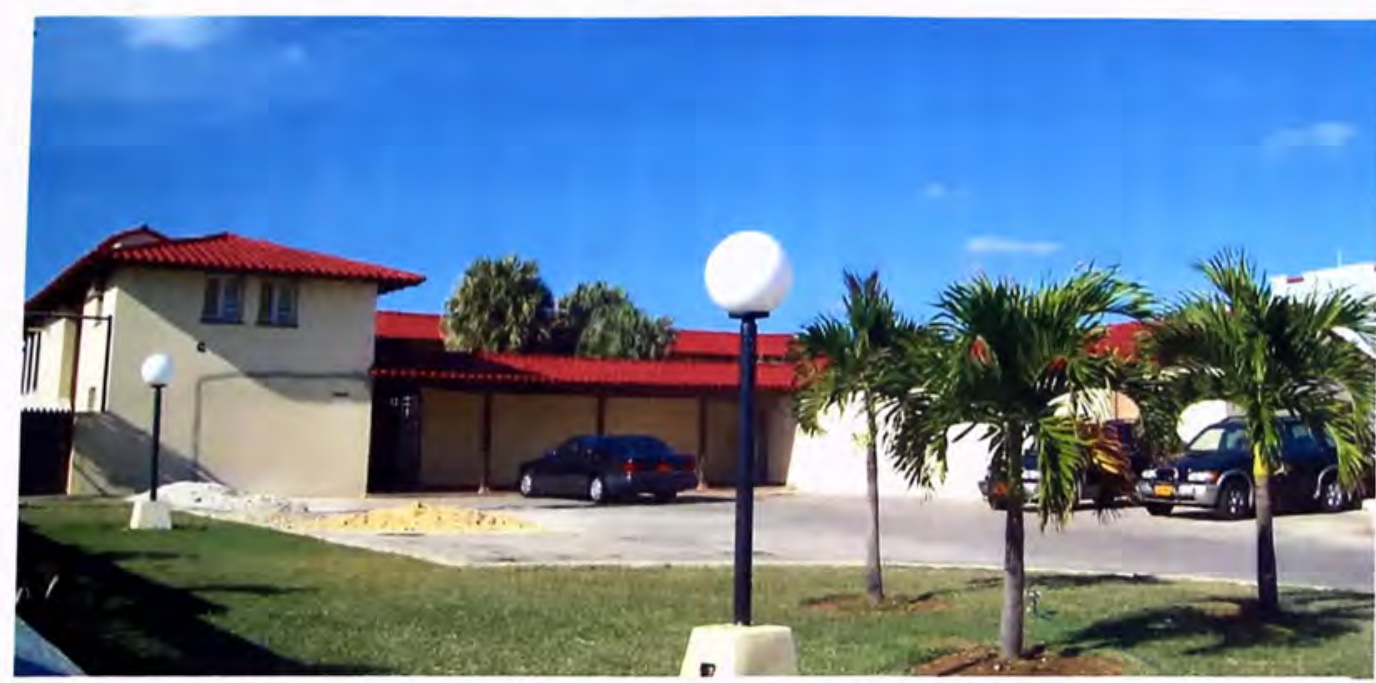

Figure 15 Front of the Eutimio Falla Bonet House

Source: Photograph taken by author (2004)

The Eutimio Falla Bonet House, deigned by Eugenio Batista and built in 1939 in the Miramar sector towards the western part Havana, was the first modern house to offer a rich reinterpretation of the thresholds and transitional spaces that create depth and movement within the colonial Cuban house. In analyzing the house, there is a sense that Eugenio Batista engaged in a mental deconstruction of these elements in order to understand their functional qualities and how they adapted to Havana's landscape. In particular, Batista reinterpreted the open spaces that allowed the weaving of family activities and the filtering of light and air such as the portal, the galeria, the traspatio, the zaguan, and the patio (in sequence).

In plan, the house is composed of three programmatic bars organized around a series of open spaces that serve as generators of family interaction and environmental integration. The western bar manifests a two-fold character defined by service spaces in front of the house and public spaces towards the back. The central bar contains private functions and the southern bar contains a garage Interestingly, the private bar serves as a threshold between a public patio towards the back of the house and the portal facing the street, maintaining, as in the colonial Cuban house, cross ventilation between two open-air spaces.

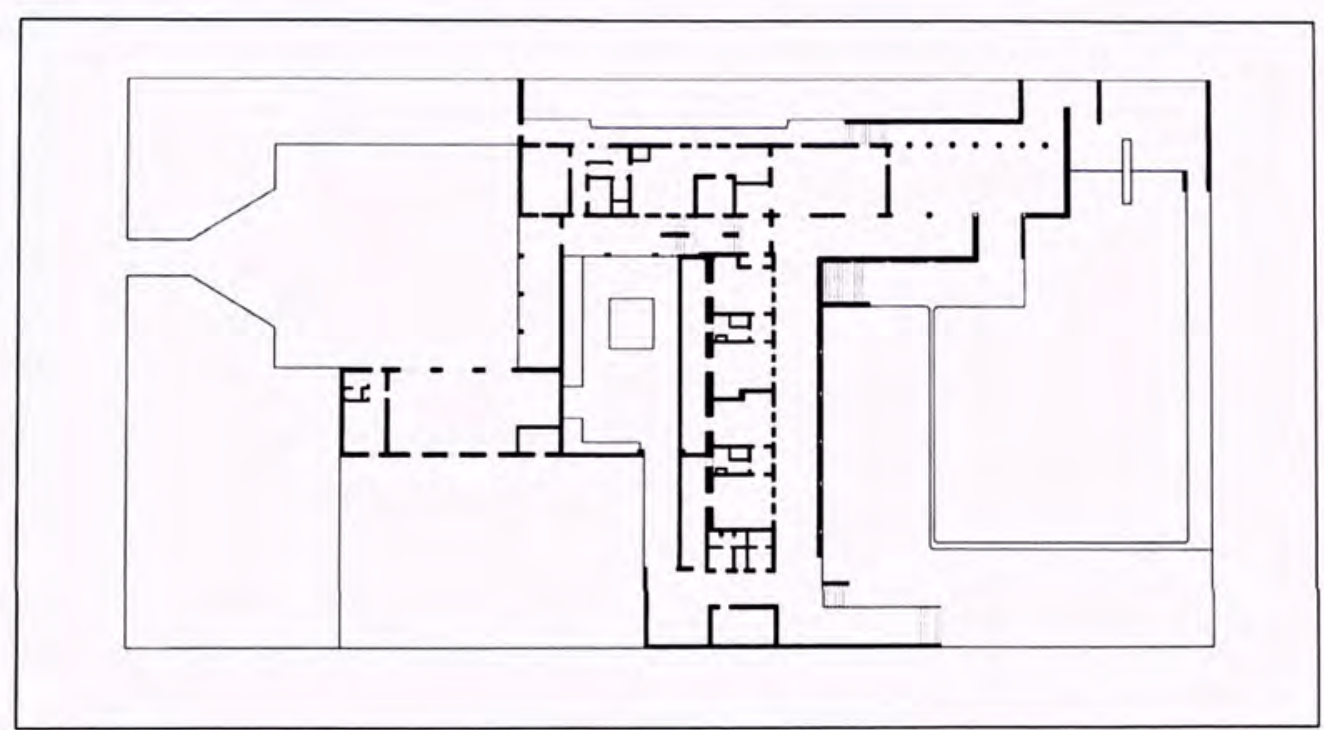

Figure 16 Floor plan of the Eutimio Falla Bonet House Source: Drawn by author (2004)

The choreography of movement within the Eutimio Falla Bonet House demonstrates a contemporary reinterpretation of the thresholds and transitional spaces of the colonial Cuban house. One moves sequentially through a series of transitional spaces in the same manner as in the colonial Cuban house yet with a modern flexibility and plasticity. 
One enters through a portal, facing the street and connecting two service spaces, which converts into a small galeria. The galeria, in turn, spills into the first private patio (or modern-day traspatio) leading into the bedrooms. As one moves further through the galeria past the patio, a stair takes him up to a zaguán which, just as in colonial Cuban House, becomes a central distribution area. From the zaguán one enters into the interior of the house or into a second galeria that overlooks a larger patio containing a large salt water pool overlooking the sea. This galeria also converts seamlessly into a smaller patio which can accommodate public household activities.

Batista reinterpreted these elements as individual parts within a modern ensemble as opposed to their rigid and systematic implementation common to colonial Cuban architecture. For example, in the colonial Cuban house the galeria and the patio were separated by columns and arches, creating visual depth on the vertical plane while remaining flat in plan. In the Eutimio Falla Bonet House, however, Batista separated the two by placing the galeria at a higher level-literally lifting one up above the patio and making the transition from galeria to patio and vice versa a physical one by choreographing a vertical movement between the two spaces. Additionally, a large overhang over the galeria draws the eye towards the façade. As a result, the house is physically deep on the horizontal plane as well as visually deep on the vertical one.

The zaguán is reinterpreted as a hidden element awaiting discovery as opposed to, as in the colonial Cuban house, an entry space layered behind the portal at the center of the façade. In order to strip it of urban connotations, Batista places the zaguán towards the back of the house, requiring one to move through a galeria before reaching it. In placing a galeria between the porfal and the zaguán Batista alters the chorography of movement typically found in Havana's colonial architecture by extending time through the creation of a path that integrates the activities of the house with the procession of movement towards its entry.
In contrast to the colonial Cuban house, the Eutimio Falla Bonet House turns its back to the street by placing public spaces in the back and private spaces in front. The result is an inversion of the spatial layering system found in colonial architecture in that the Eutimio Falla Bonet House is layered from private to public as opposed to being layered form public to private, further emphasizing Batista's reinterpretation of Havana's social and cultural context. In his essay The Cuban House: Patios, Portales y Persianas, Batista states that:

We only have to point out the radical changes produced by the automobile and the telephone. In times of the horse and carriage, it was an obligatory pastime (as well as very pleasant, despite it being virtually the only one available) of our grandparents to sit in their porches in the late afternoons to greet their acquaintances passing by. The time that a carriage took to pass by the front of the house allowed an opportunity not only for the exchange of greetings, but also for the inquiries about the family. Today, if it occurs to us to sit looking out toward a busy street, in ten inquiries about the family. Today, if it occurs to us to sit looking out toward a busy street, in ten
minutes we are dazed by the vertiginous and incessant flow of unrecognizable vehicles that traverse the city. ${ }^{17}$

Batista understood that modernity brought about social changes that could not be ignored. At the same time, he also understood that, despite these social changes, Havana's climate and landscape remained the same.

\footnotetext{
${ }^{17}$ Translated from Spanish to English by Raúl Garcia
} 


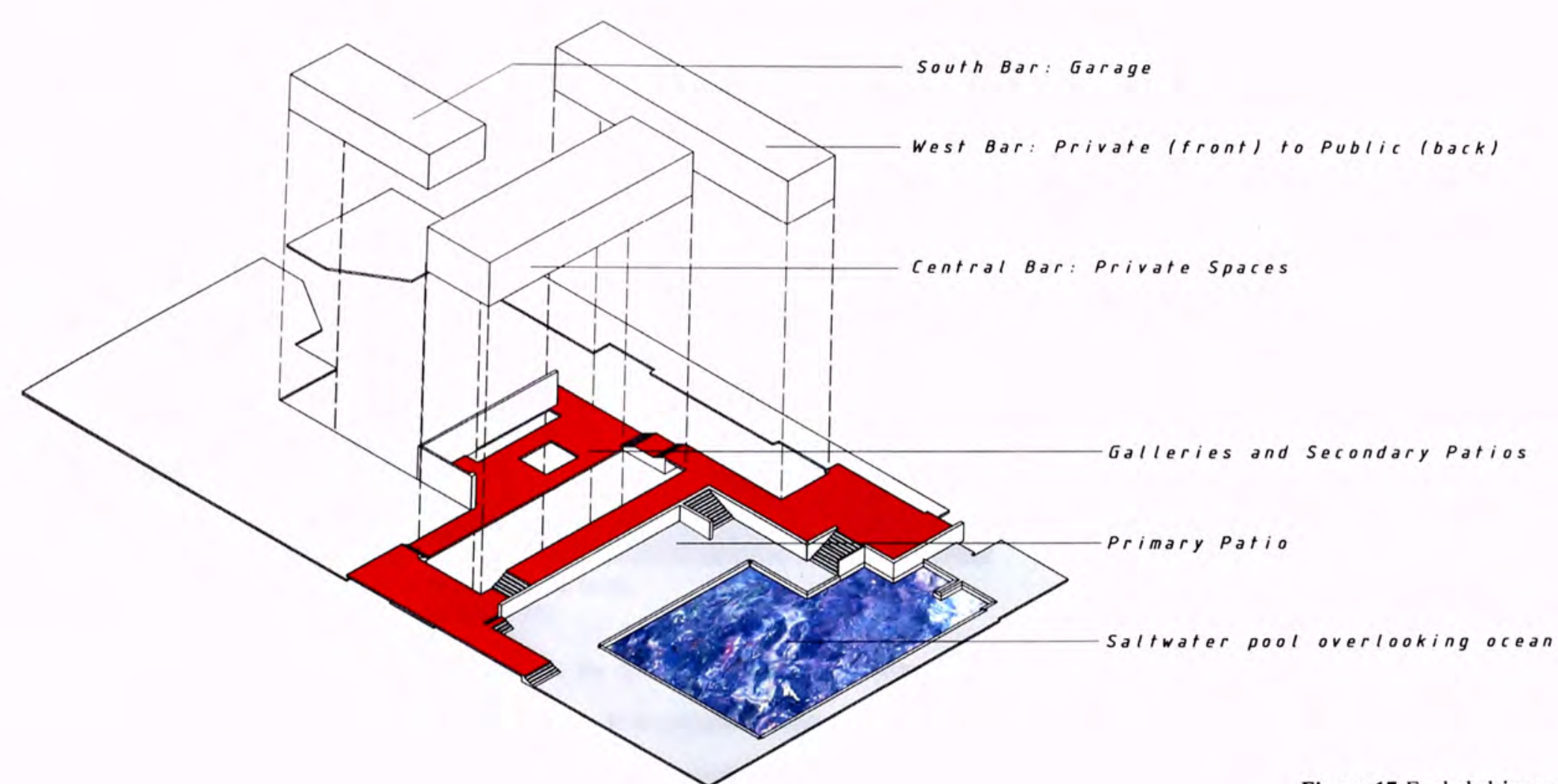

Figure 17 Exploded isometric diagram of the Eutimio Falla Bonet House showing programmatic distribution and the transitional spaces of the Eutimio Falla Bonet house. Note the placement of stairs in between transitional zones.

Source: By author (2004) 


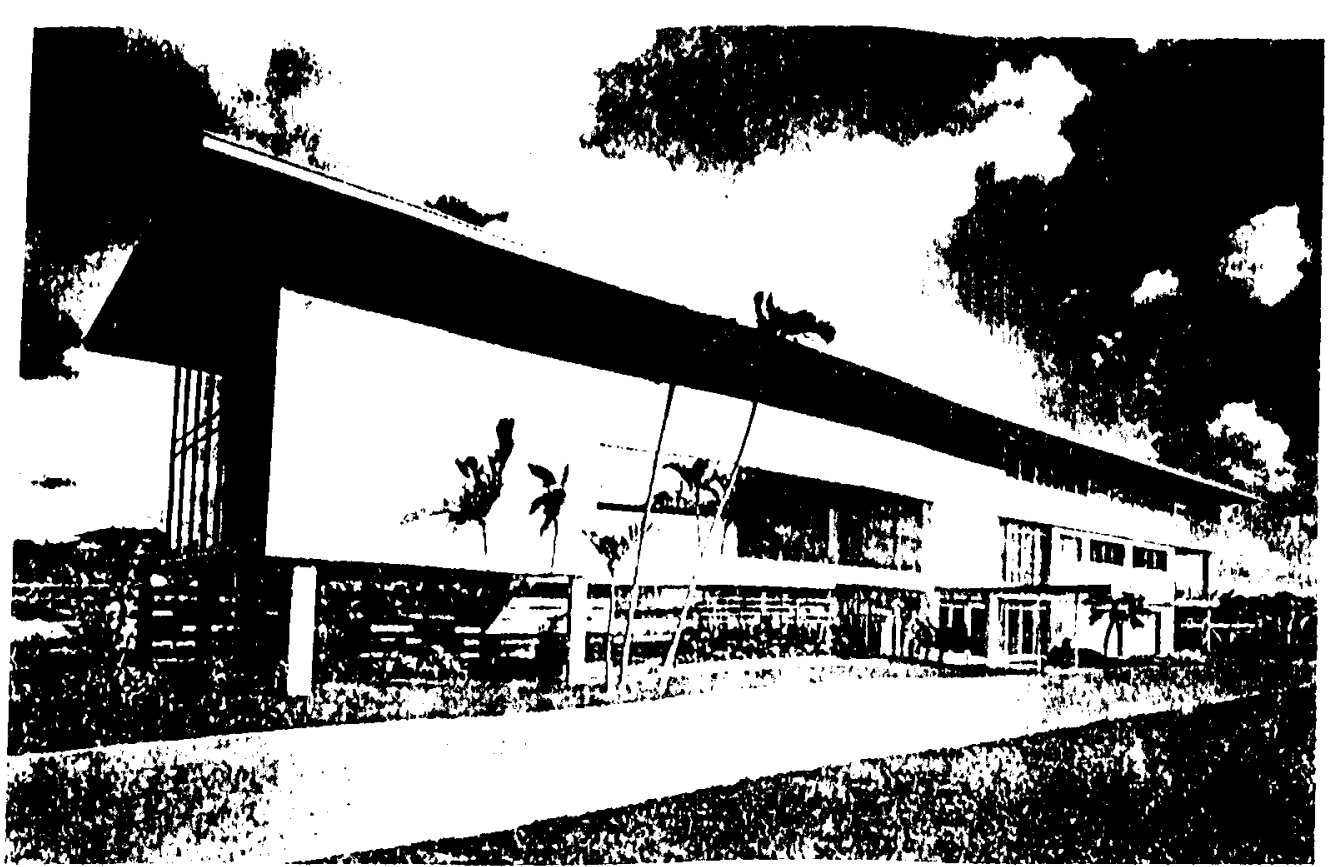

Figure 18 Front and back photographs of the José Noval Cueto House

Source: The Havana Guide: Modern Architecture 1925-1965

The House built for José Noval Cueto in 1949 was the first Rationalist work in Havana to integrate European Rationalism with Havana's cultural landscape. It demonstrates a masterly integration with Havana's tropical climate through its orientation and careful articulation of open spaces and gardens. Like the Eutimio Falla Bonet House, the José Noval Cueto House offers a modern reinterpretation of the thresholds and transitional spaces of the colonial Cuban house.

The house is composed of two volumes (one of them two stories to the left and the other three stories to the right) oriented linearly and tied together by a large patio on the ground level and galerias on the upper levels. Following Miesian Rationalist principles of spatial articulation through extended

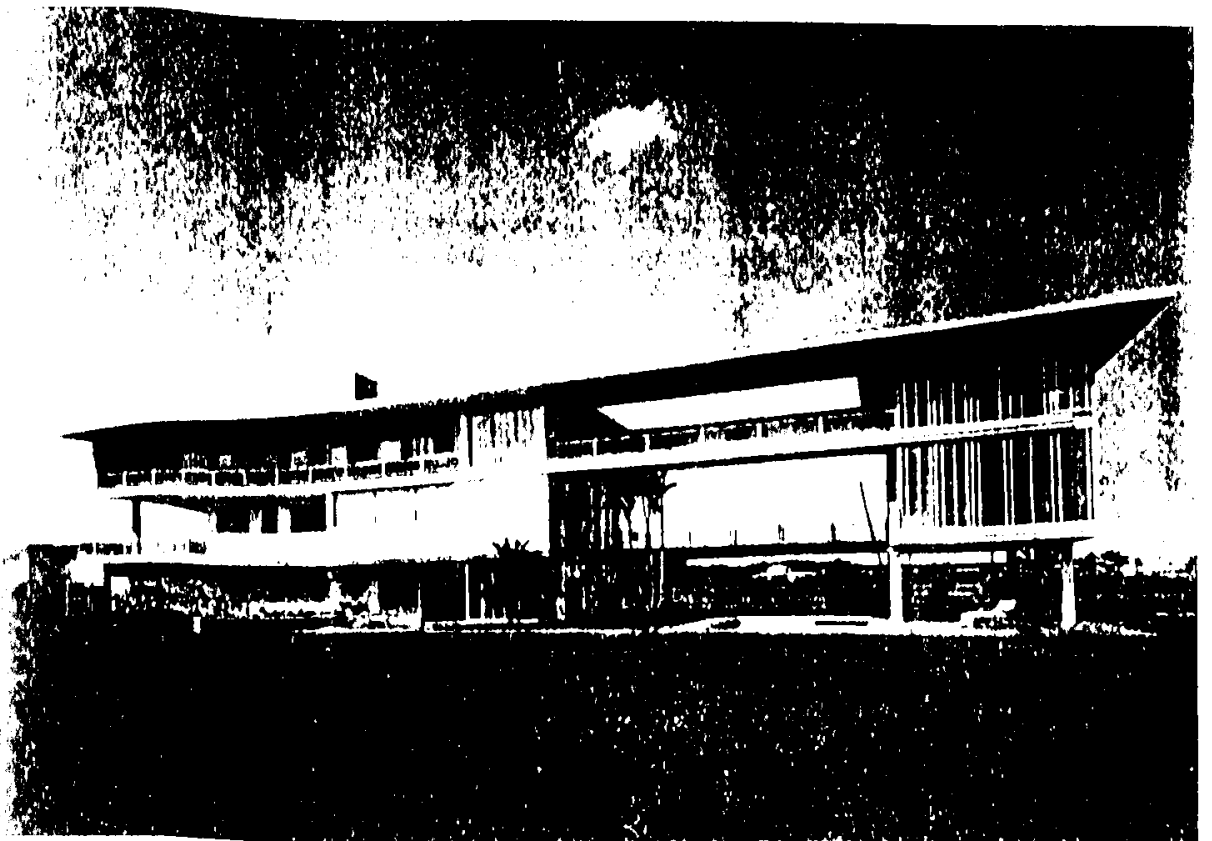

planes, Romañach and Bosch conceptually pulled the two volumes apart leaving only transitional spaces in between and providing a dynamic sequence of movement.

The volume to the left (front view) contains a double-height living room with a galeria at its periphery that leads into the bedrooms. This volume is lifted off the ground on pilotis and separated from the rest of the house for privacy. The other volume contains an entry, a bar, a two-car garage, and a service terrace on the ground floor, a kitchen and two servant's quarters on the first floor, and three bedrooms on the third floor.

These spaces are sandwiched in between two aesthetically different façades (front and back). The façade that faces the street has a solid character expressed by concrete walls with punched openings 
while the one that faces the garden is open and transparent through large expanses of glass. The house turns its back to the street and opens onto a patio and garden.

The house is oriented carefully to funnel breezes inside. By lifting the house off the ground, Romafiach and Bosch designed for a constant circulation of air beneath the house. This, combined with the large pool in the patio maintains the house cool during Havana's long hot summers.

Romanach and Bosch were clearly aware of the spatial organization of the colonial Cuban house in terms of sequence and its thresholds and transitional spaces. Like the colonial Cuban house, one enters on the ground floor through a zaguán where he is then distributed through the house--to the left, a galeria leading out to the landscaped patio, to the right, the bar, or up stairs to the second floor. On the second floor one lands in another zaguän-like space where he is distributed in the same fashion-to the left, a galeria leading into the living room, to the right, the kitchen, or up stairs to the third level where the same sequence of movement repeats.

This creates a sensual dialog between interior and exterior spaces as one walks from one side of the house to the other. During the procession, one goes from an enclosed, programmatically defined interior space into a programmatically undefined open space and back into an interior space. It is the second point of procession that marks the fundamental concept of this house-where one experiences nature and family activities simultaneously. Furthermore, the two galerias converge to become a floating two-faced façade that allows a juxtaposition of activities and experiences, much like in the colonial Cuban house.

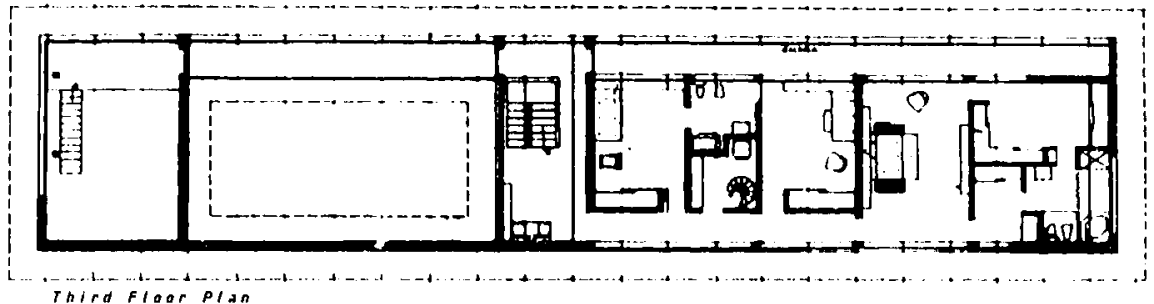

Third fioar plan
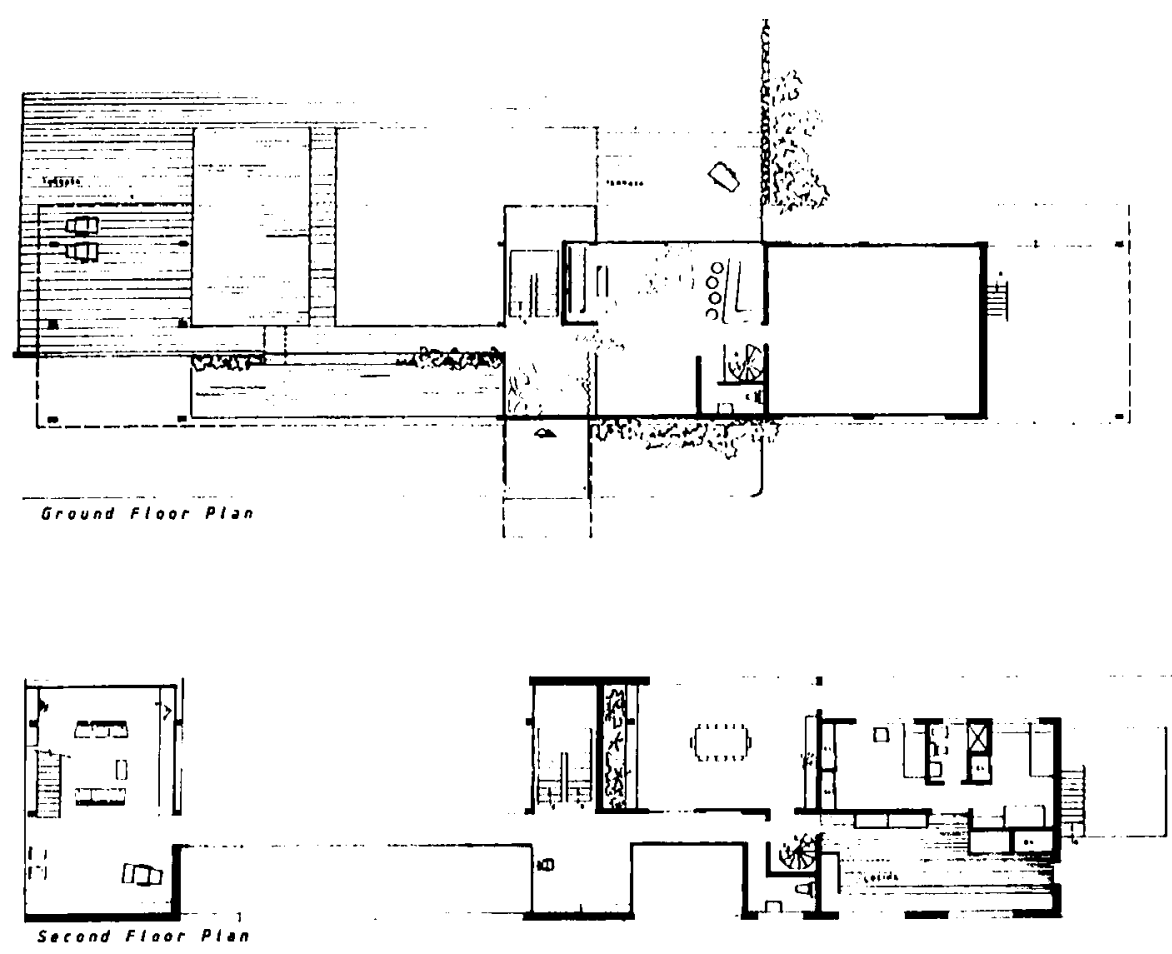

Figure 19 Floor plans of the José Noval Cueto House

Source: The Havana Guide: Modern Architecture 1925-1965 


\section{SITE ANALYSIS}

4 Brief History of the Plaza Vieja

The Plaza Vieja is Old Havana's most culturally significant social plaza. As Old Havana's second oldest plaza, it served as a domestic square used specifically for recreation, commercial, and domestic purposes (markets, social parties, etc.) in response to the military occupation of the city's founding plaza, the Plaza de Armas. It was Havana's first attempt at city growth and in turn the first urban space with great social significance excluding military or religious activity.

Founded in 1559, the quadrilateral square occupies the intersection between San Ignacio, Mercaderes, Teniente Rey, and Muralla streets. The plaza was known as the Plaza Nueva until after 1835 when it became the Plaza Vieja in order to distinguish it from the newly formed market opened at the Plaza de Cristo. A period of deterioration began in 1835 with the construction of the Mercado de Cristina, built by Governor Tacón's administration, which took up the entire open space and resulted in the disappearance of the square. In 1908, the market building was destroyed and the plaza began to regain social importance until 1952, when a partially sunken parking garage was built (designed by Eugenio Batista) in its place. The parking garage was destroyed in 1998 and the plaza is currently undergoing restoration.

In contrast to all the other plazas in Old Havana, the buildings surrounding the Plaza Vieja were primarily domestic, each one with a portal on the ground level. Some of these buildings stand as Old Havana's most significant colonial houses such as La Casa del Conde de Casa Lombillo (House of the Count of Lombillo's House) and La Casa del Conde de San Juan de Jaruco (House of the Count of Jaruco). It was not until the twentieth century that buildings of different uses and styles were built such as the Hotel Cueto (1906) in the Art Nouveau style and a couple of eclectic buildings which pretend to be contextual.

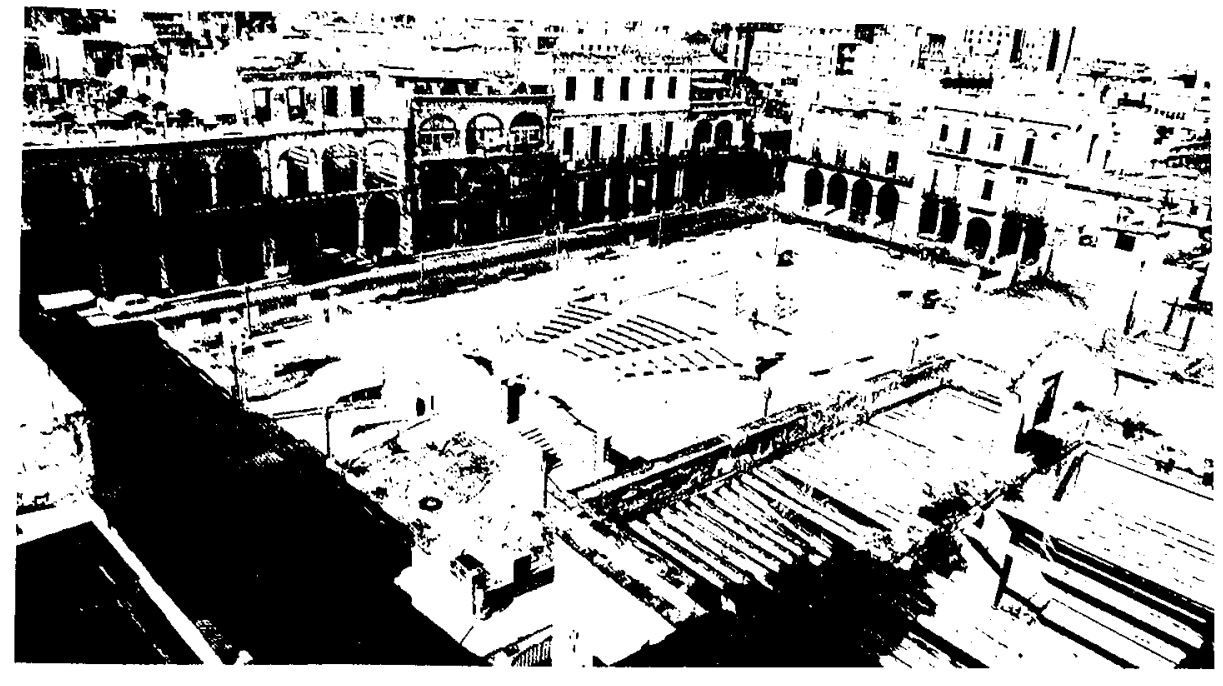

Figure 20 Plaza Vieja with parking garage. In 1952 this intrusive semi-sunken parking garage, which was designed by Eugenio Batista, was built.

Source: Arquitectura / Cuba 355-56, 1983

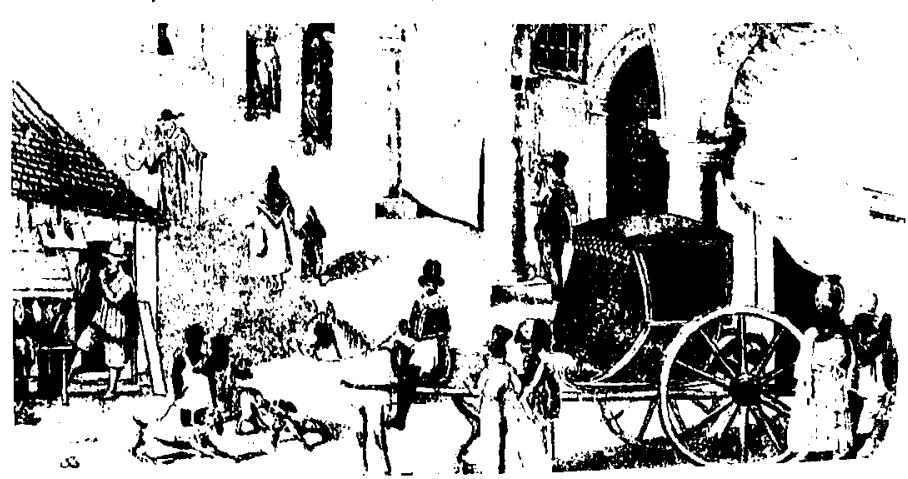

Figure 21 Plaza Vieja in the $17^{\text {th }}$ century. Source: Arquitectura / Cuba 355-56, 1983 


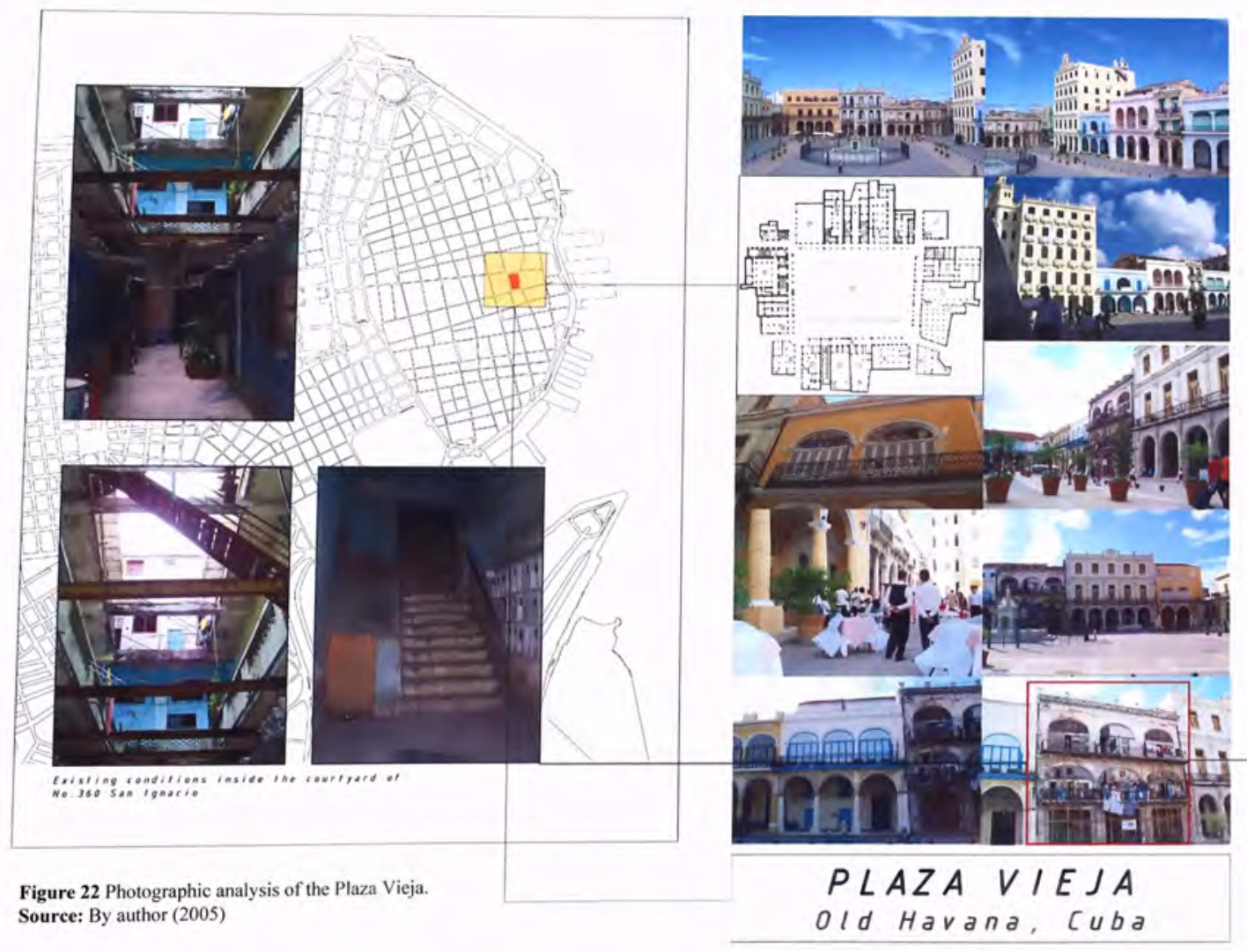




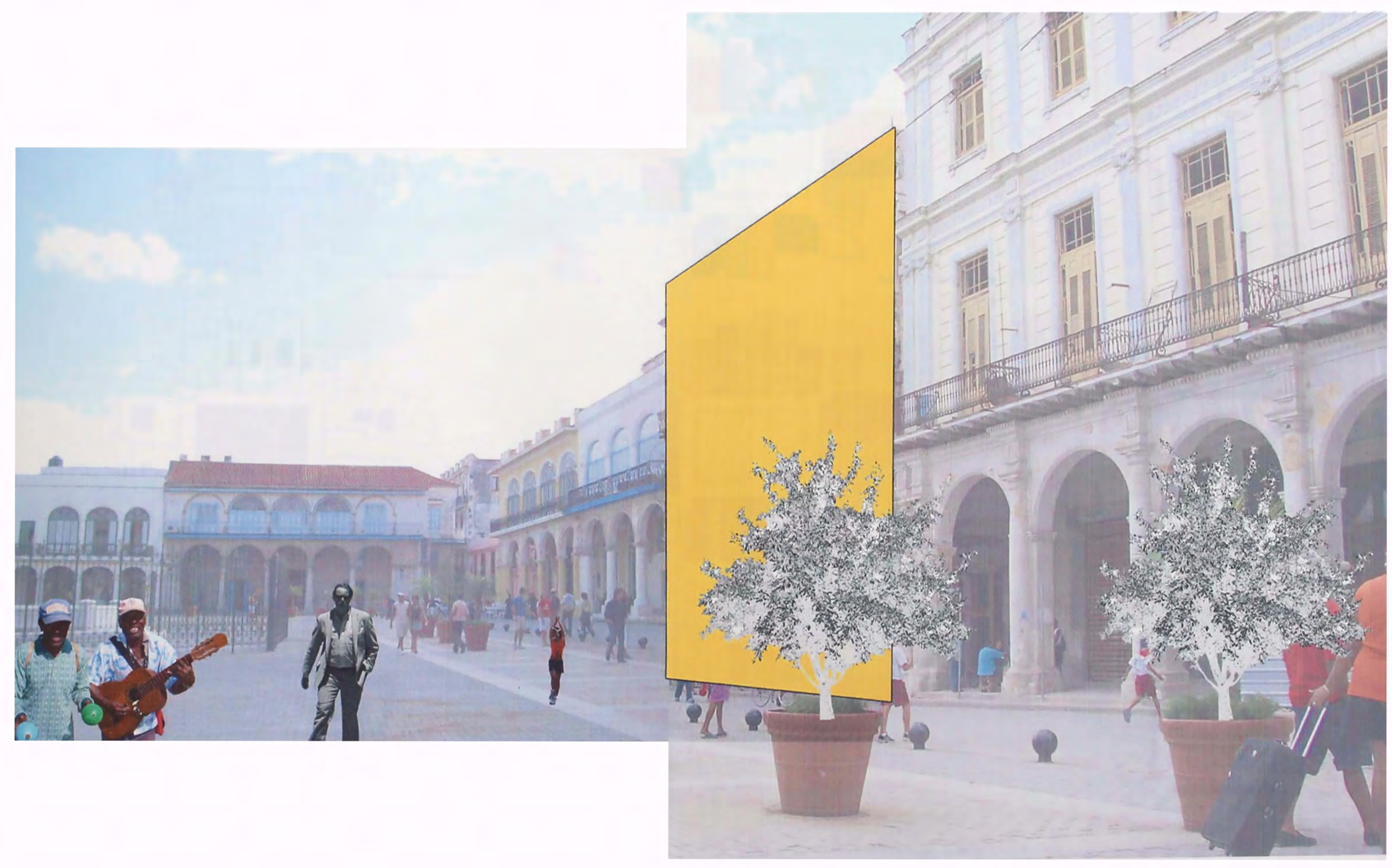

Figure 23 Character collage of the Plaza Vieja.

Source: By author (2005) 

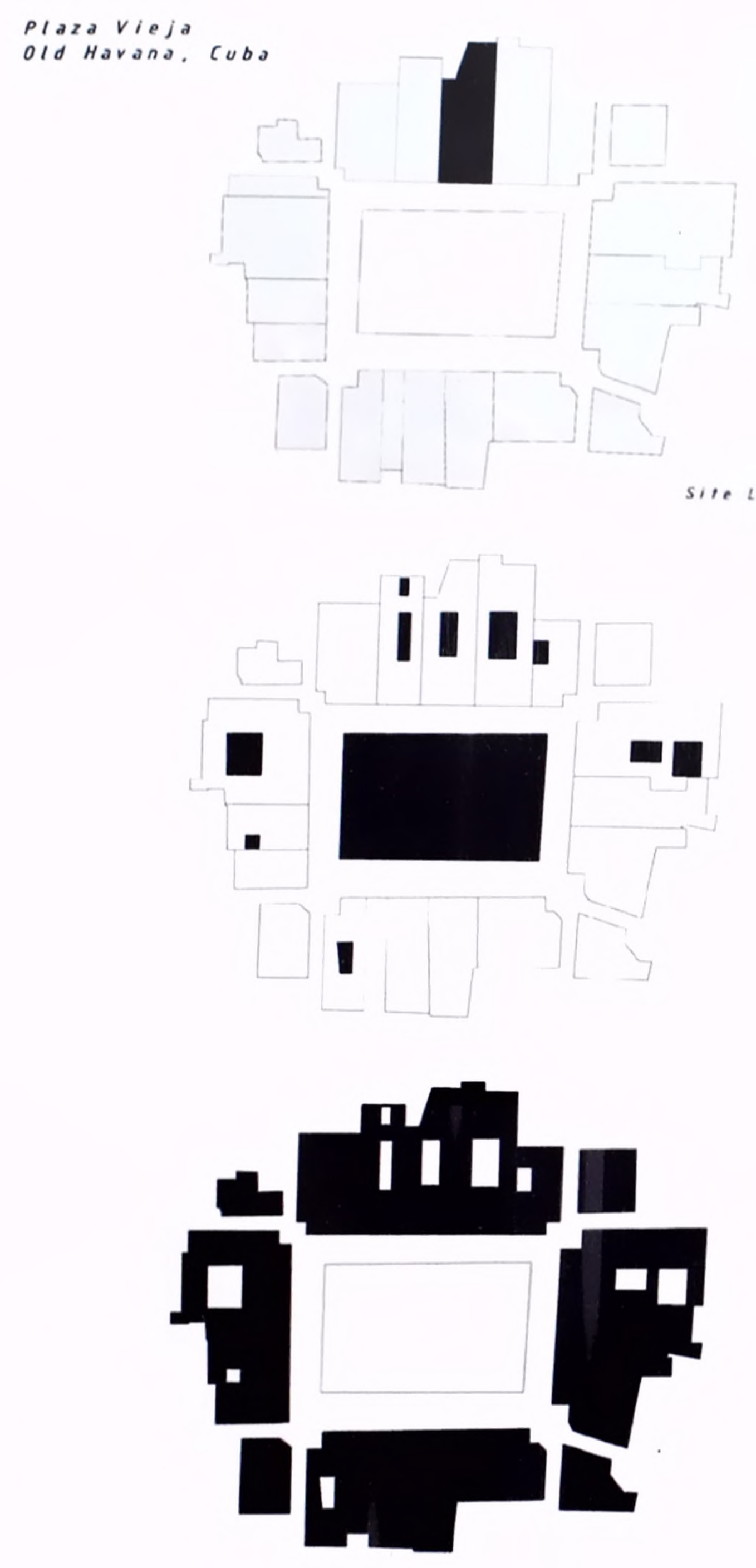

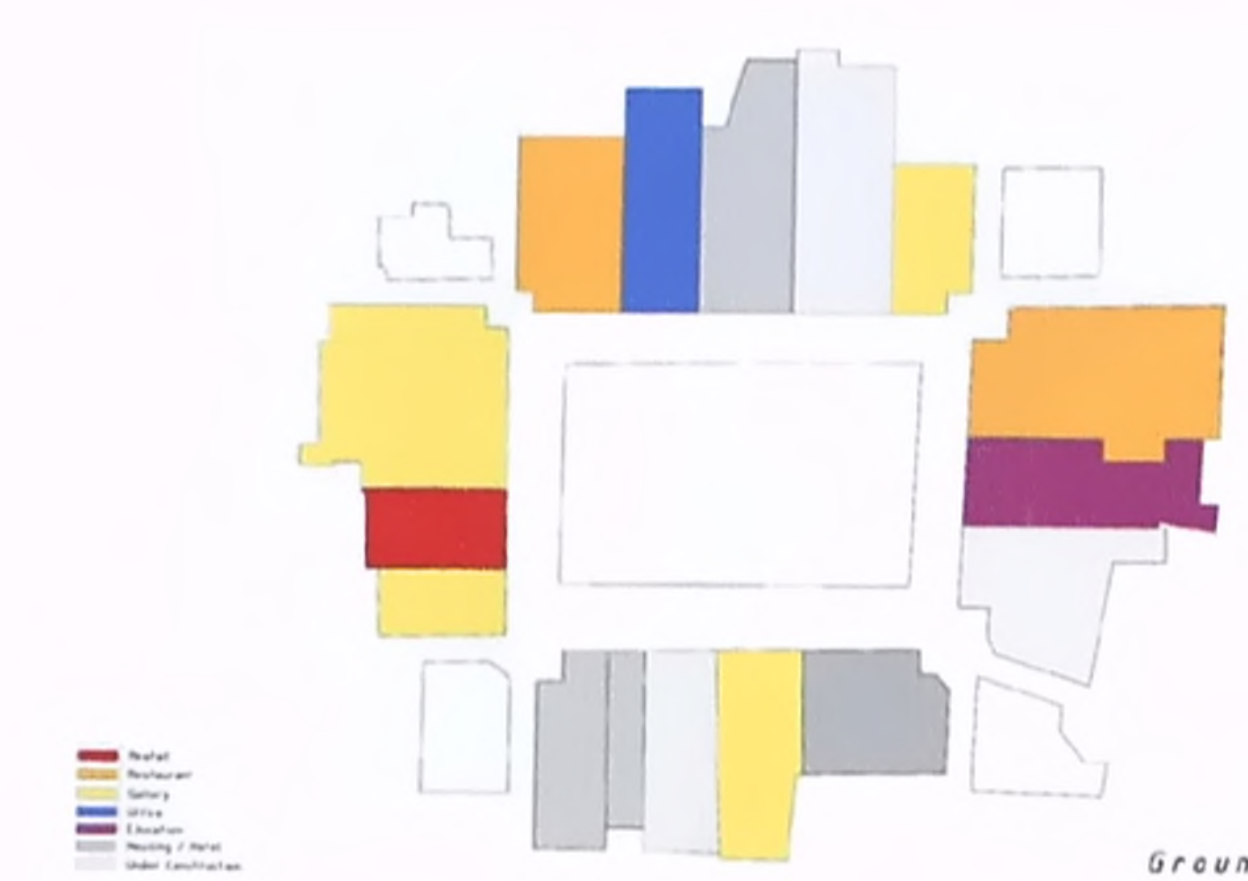

Ground floor Usage

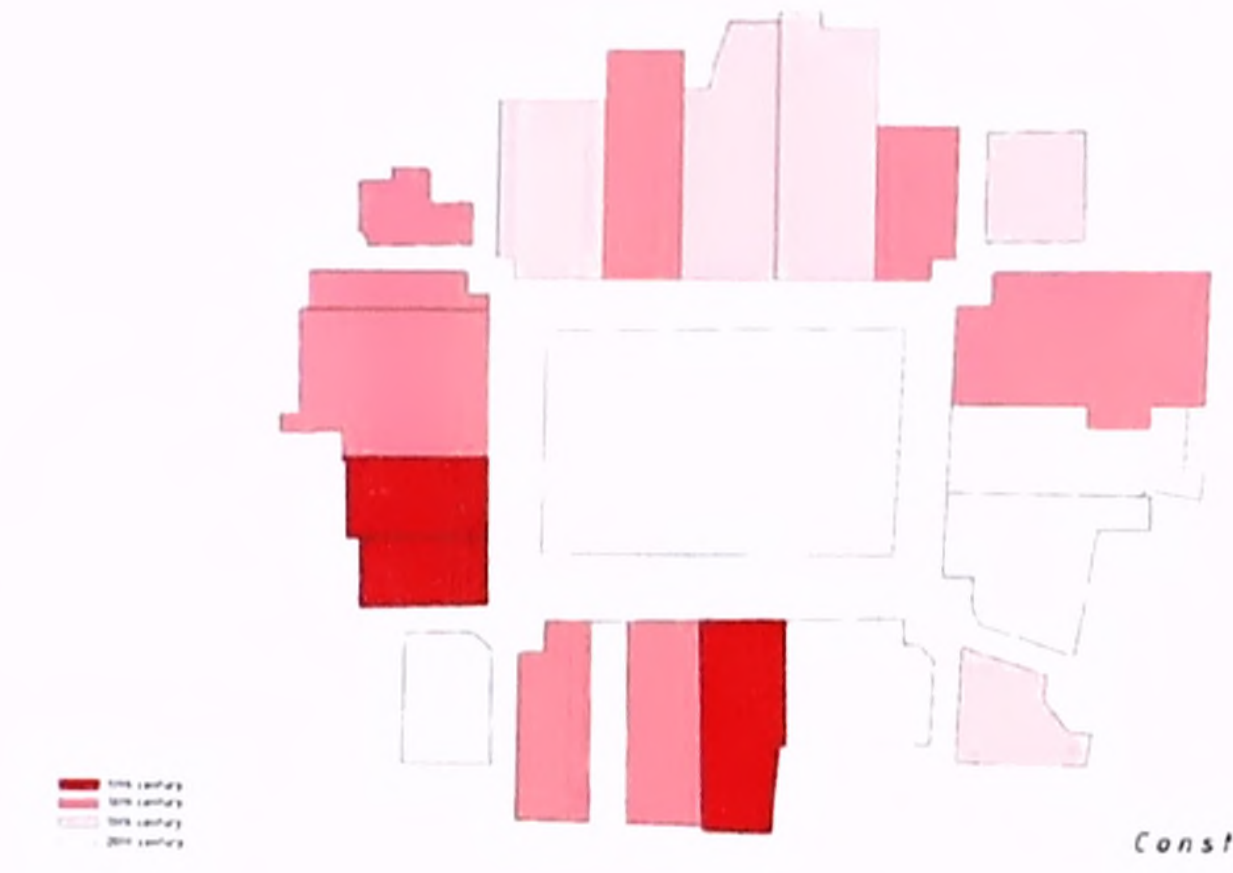

construction ero

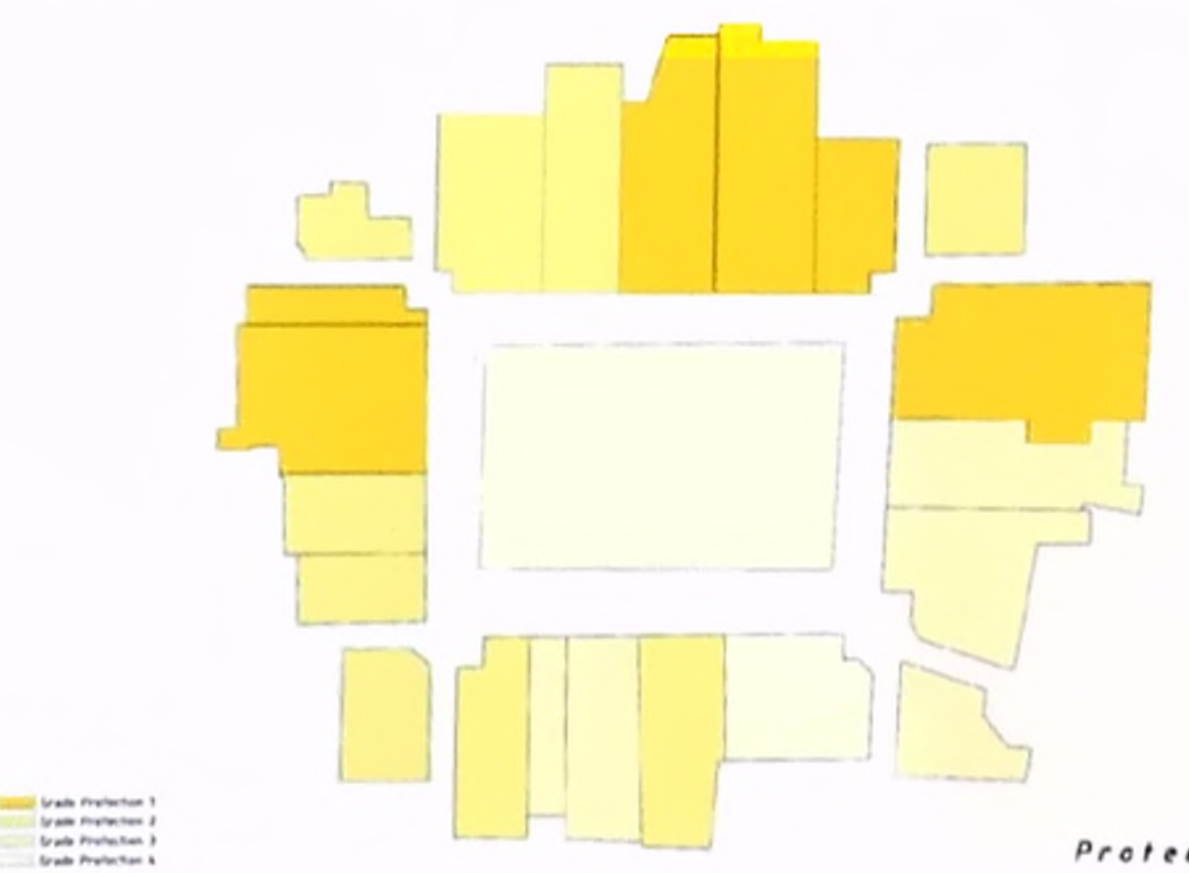

Protection Levels
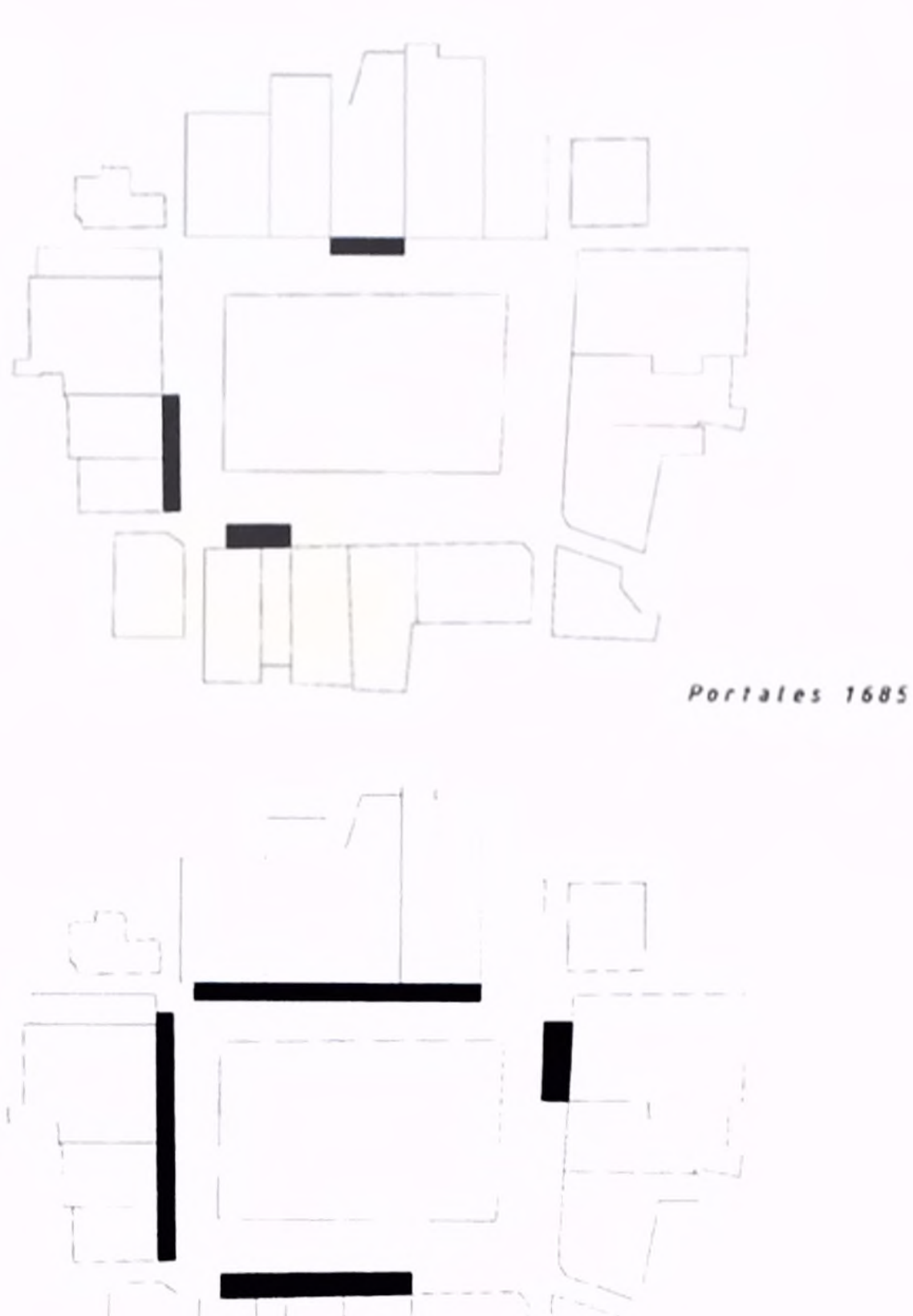

Portoles 1762

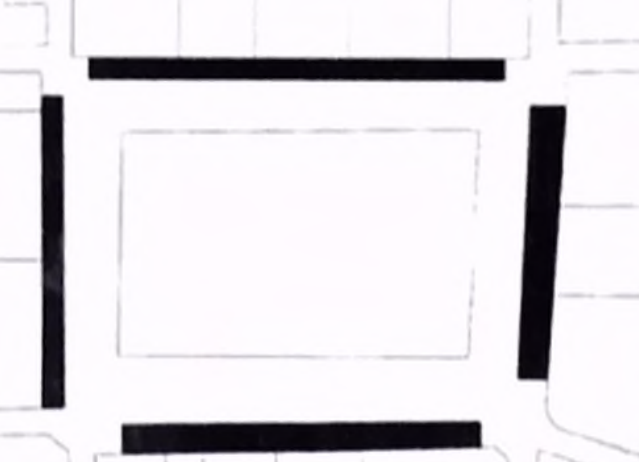

porroles 1960

Figure 24 Analytical diagrams of the Plaza Vieja. Source: By author (2005) 

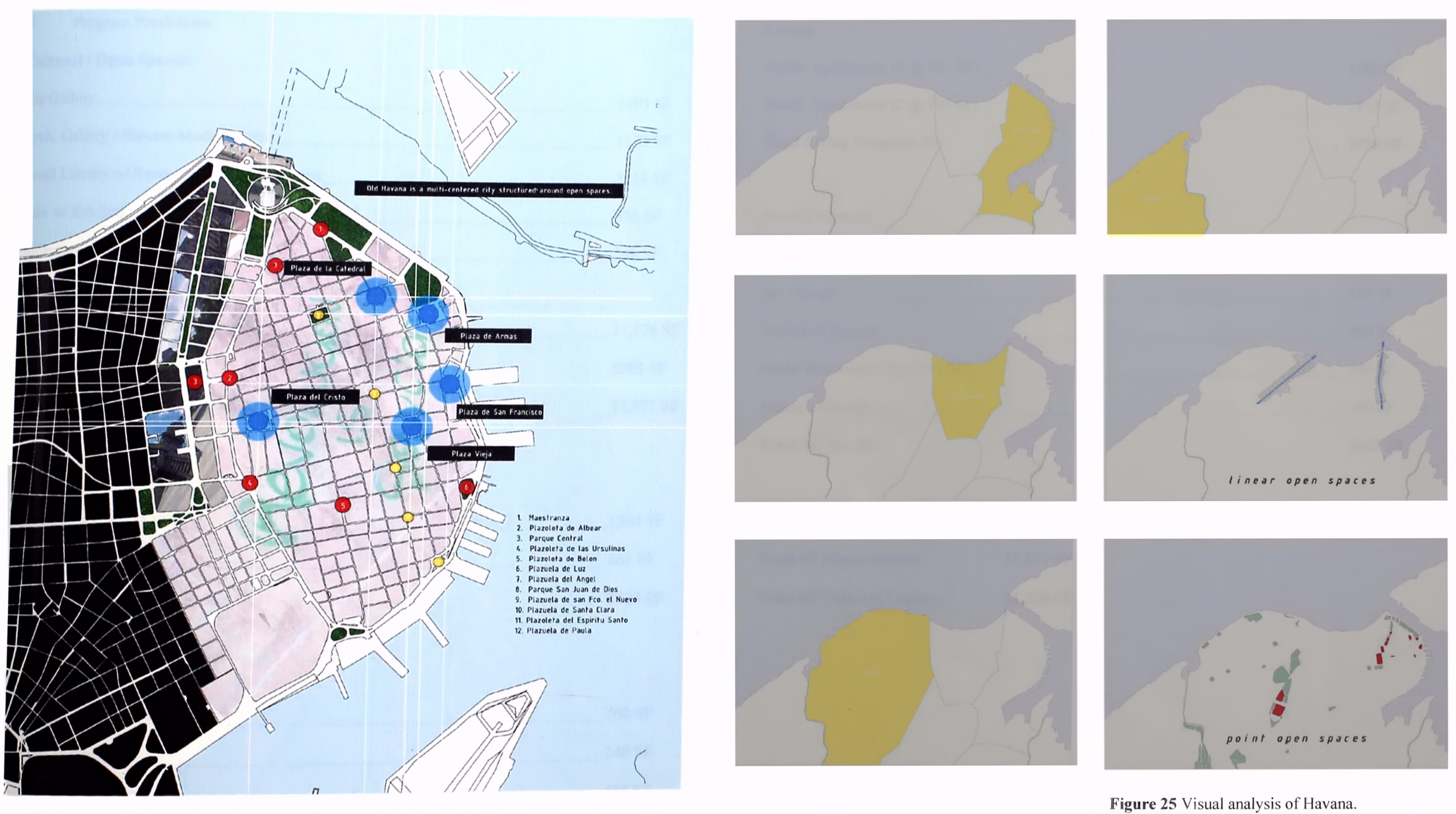

Figure 25 Visual analysis of Havana. Source: By author (2004-2005) 


\section{DESIGN PROPOSAL: MIXED-USE CULTURAL CENTER}

5 Program Breakdown

\section{Cultural / Open Spaces:}

Art Gallery

$1483 \mathrm{SF}$

Arch. Gallery / Havana Model Display

$1132 \mathrm{SF}$

Small Library w/ Research and Reading Area

Cafe w/ Kitchen

$574 \mathrm{SF}$

Bookstore

$548 \mathrm{SF}$

Public Open Spaces, Transitional Spaces, and Circulation Spaces

(Portal, Zaguán, Courtyards, Galerias, Balconies,

Grand Stair, Ramps, and Landings)

$11,676 \mathrm{SF}$

Total Cultural Program SF:

5901 SF

Total Cultural / Open Spaces SF Combined:

$17,577 \mathrm{SF}$

\section{Educational:}

Classrooms (4@341 SF)

$1364 \mathrm{SF}$

Lecture Room

Total Educational Program SF:

2025 SF

\section{Work:}

Art / Design Studios (3 @ 256 SF)

$768 \mathrm{SF}$

Director's Office

$240 \mathrm{SF}$

Offices(3@135 SF)

Total Work Program SF
Living:

Studio Apartments (2 (a) 693 SF).

Studio Apartments (2@ $705 \mathrm{SF}$ ).

Total Living Program SF:

$2796 \mathrm{SF}$

\section{Service / Other}

General Storage

$524 \mathrm{SF}$

Art Storage

Technical Support

$400 \mathrm{SF}$

Public Restrooms (2@200 SF)

$400 \mathrm{SF}$

Janitor's Storage

$100 \mathrm{SF}$

Total Service SF

$1643 \mathrm{~S}$

\begin{tabular}{ll} 
Total SF (Enclosed Space): & $13,778 \mathrm{SF}$ \\
\hline Total SF (Open Space): & $17,577 \mathrm{SF}$ \\
\hline Total SF Cultural Center: & $31,355 \mathrm{SF}$
\end{tabular}




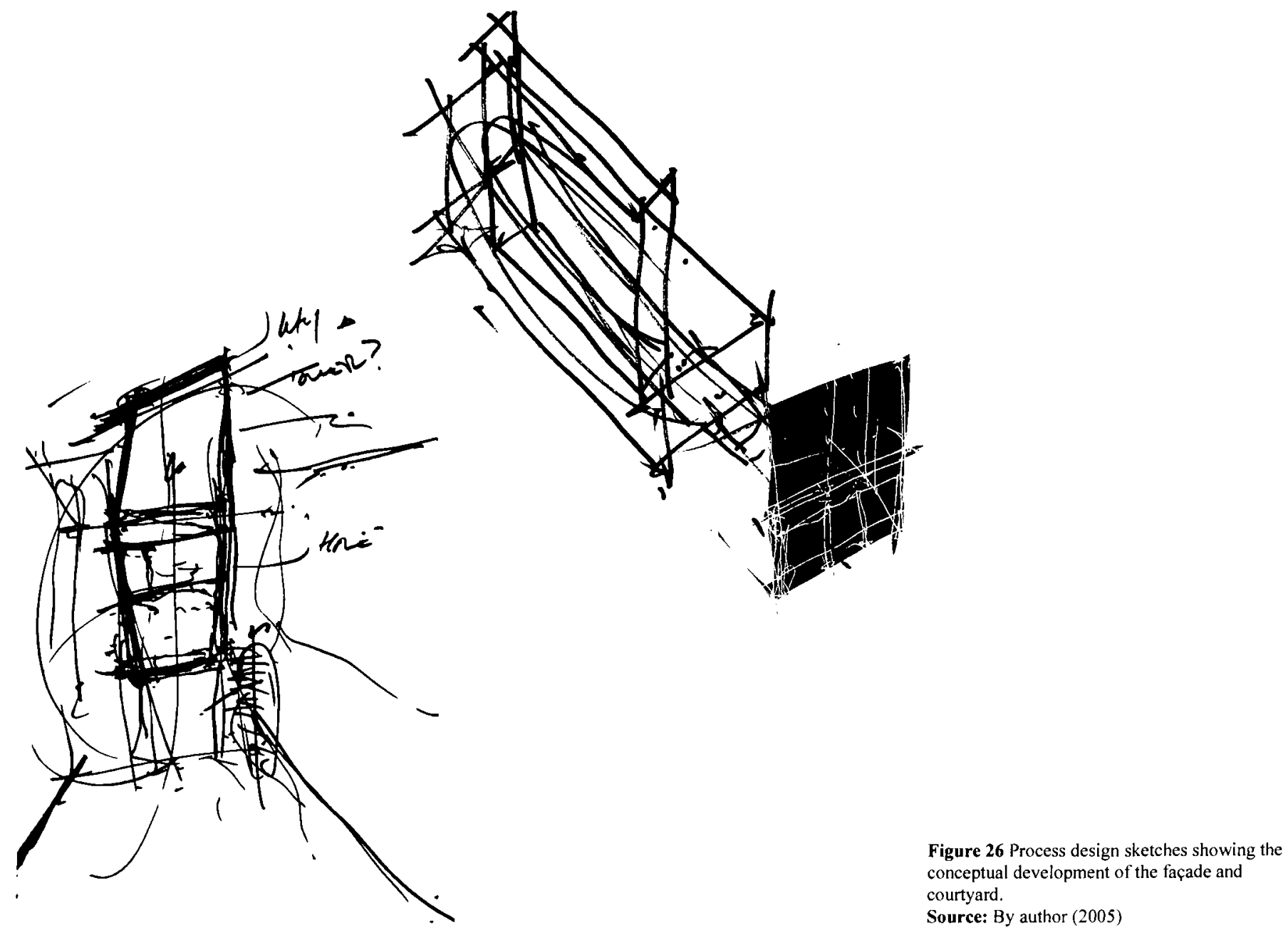



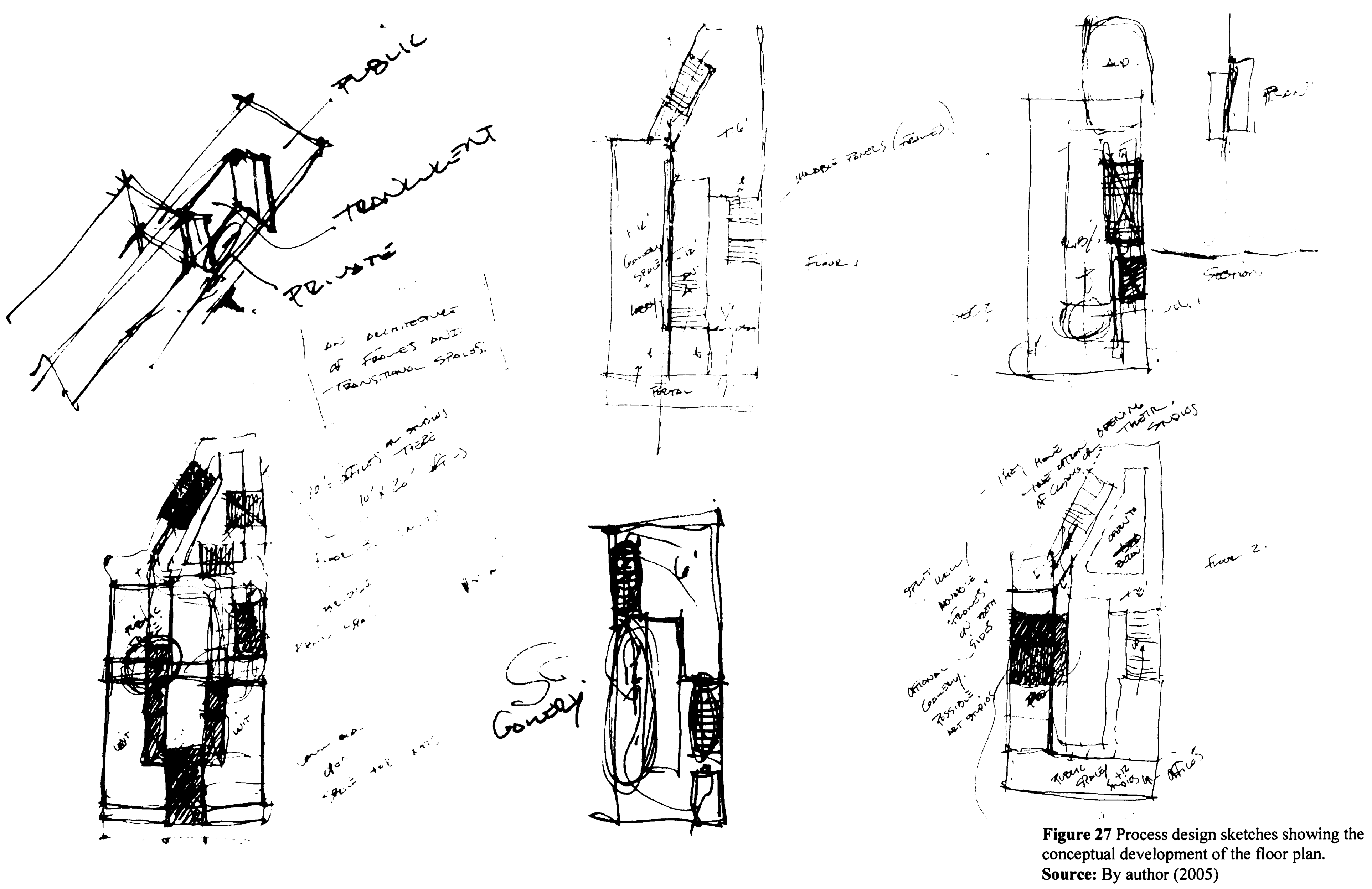

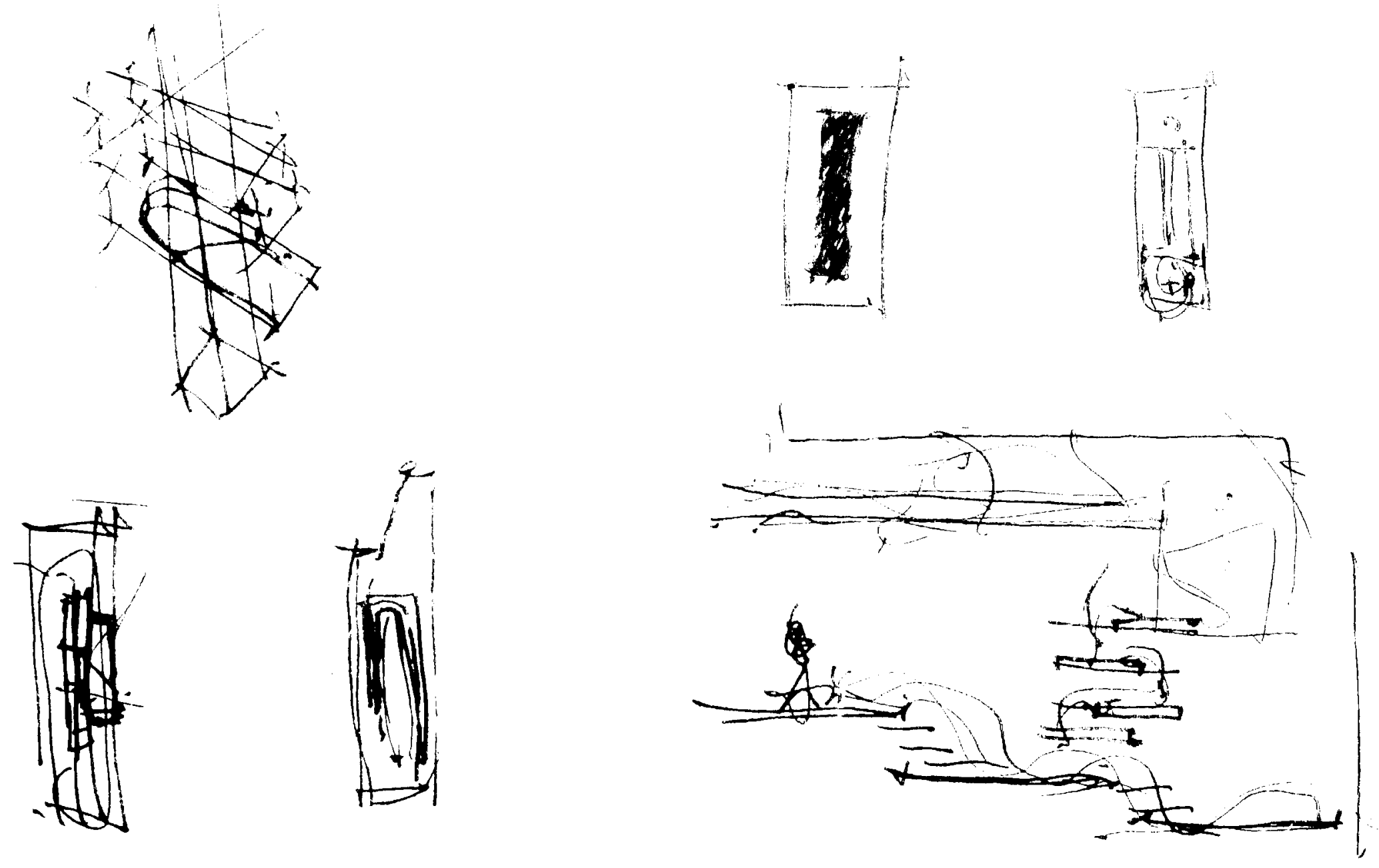

Figure 28 Process sketches showing the conceptual development of the floor plan and

Source: By author (2005) 

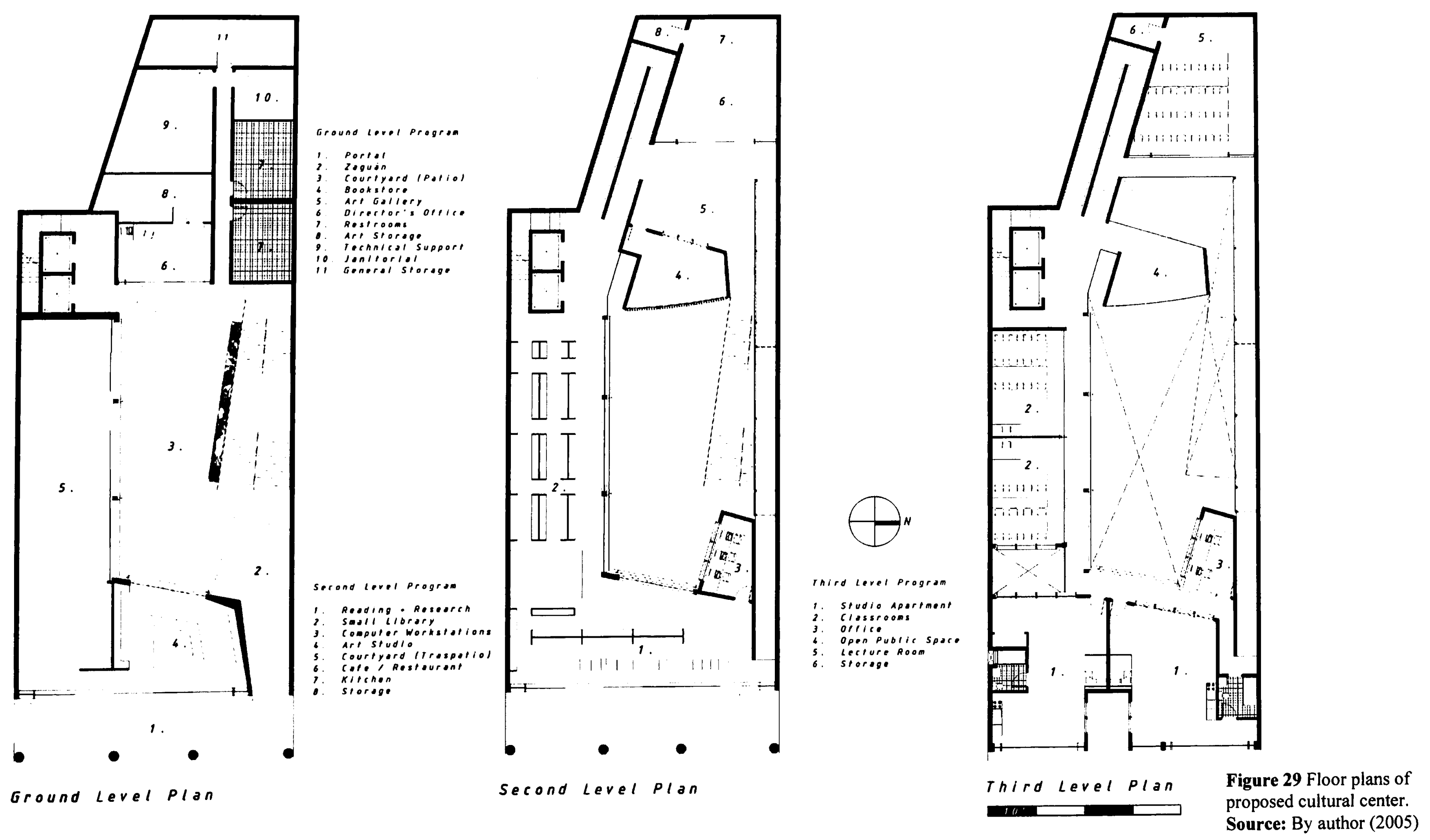

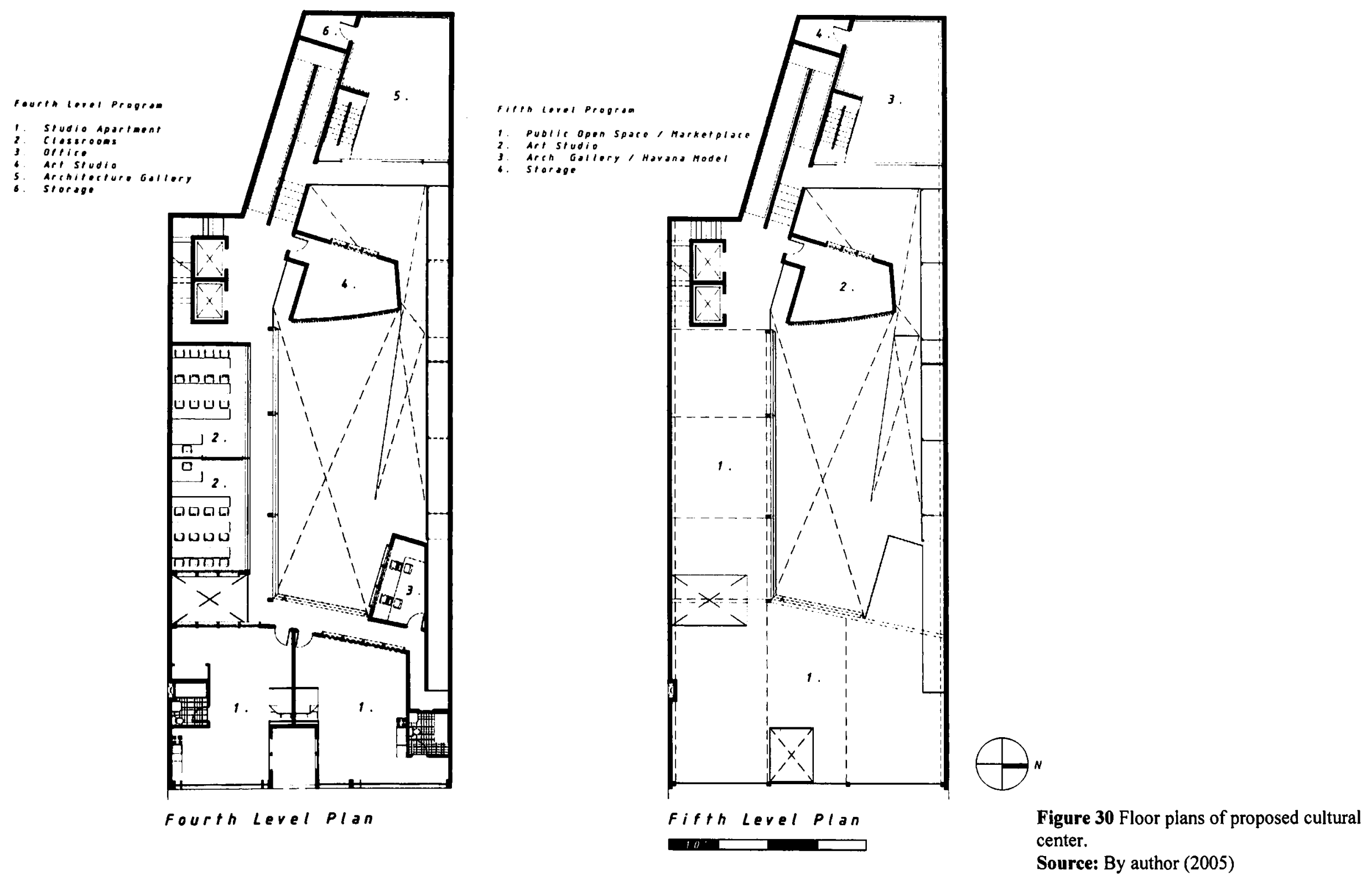

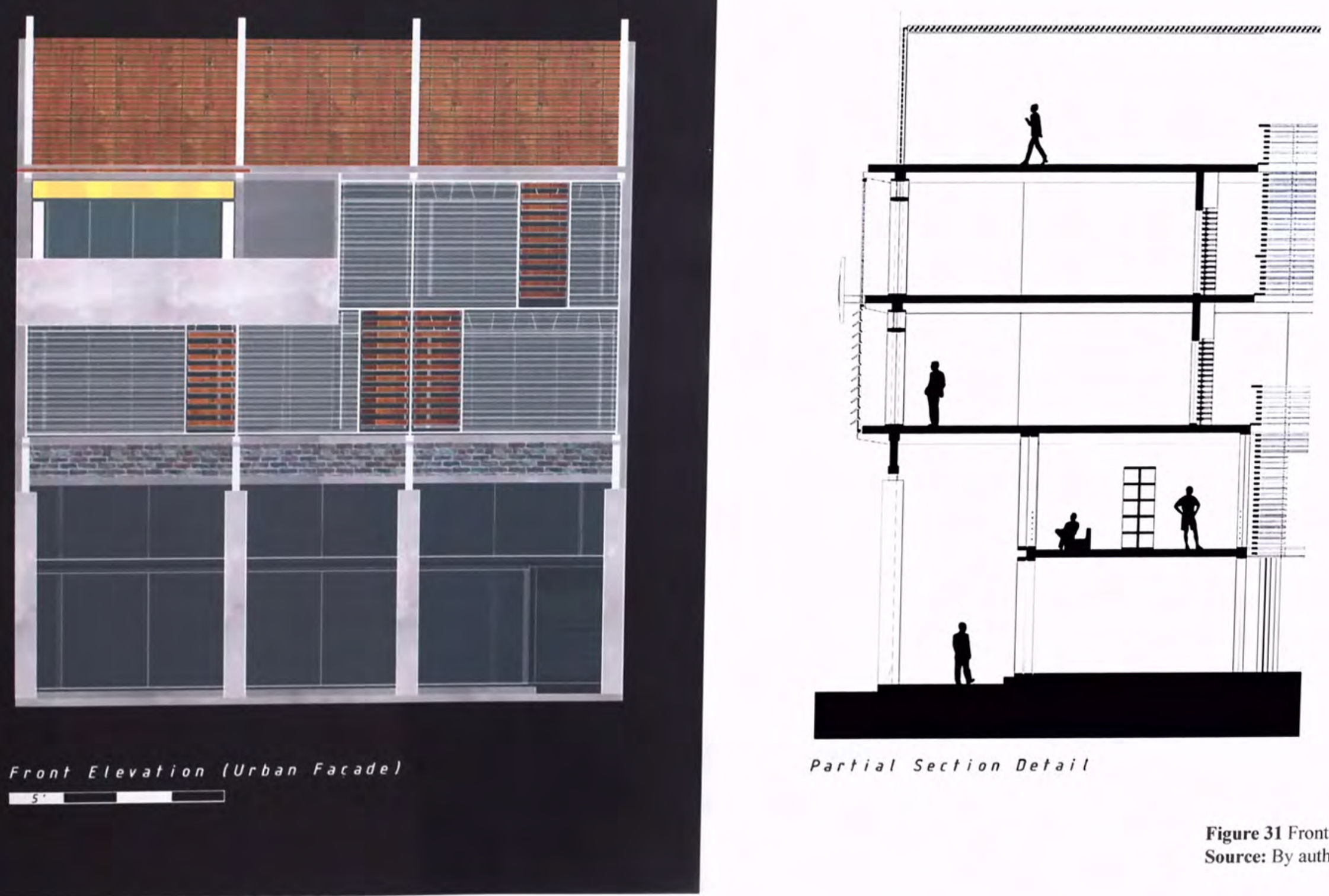

Partial Section Detail

Figure 31 Front elevation and section detail. Source: By author (2005) 


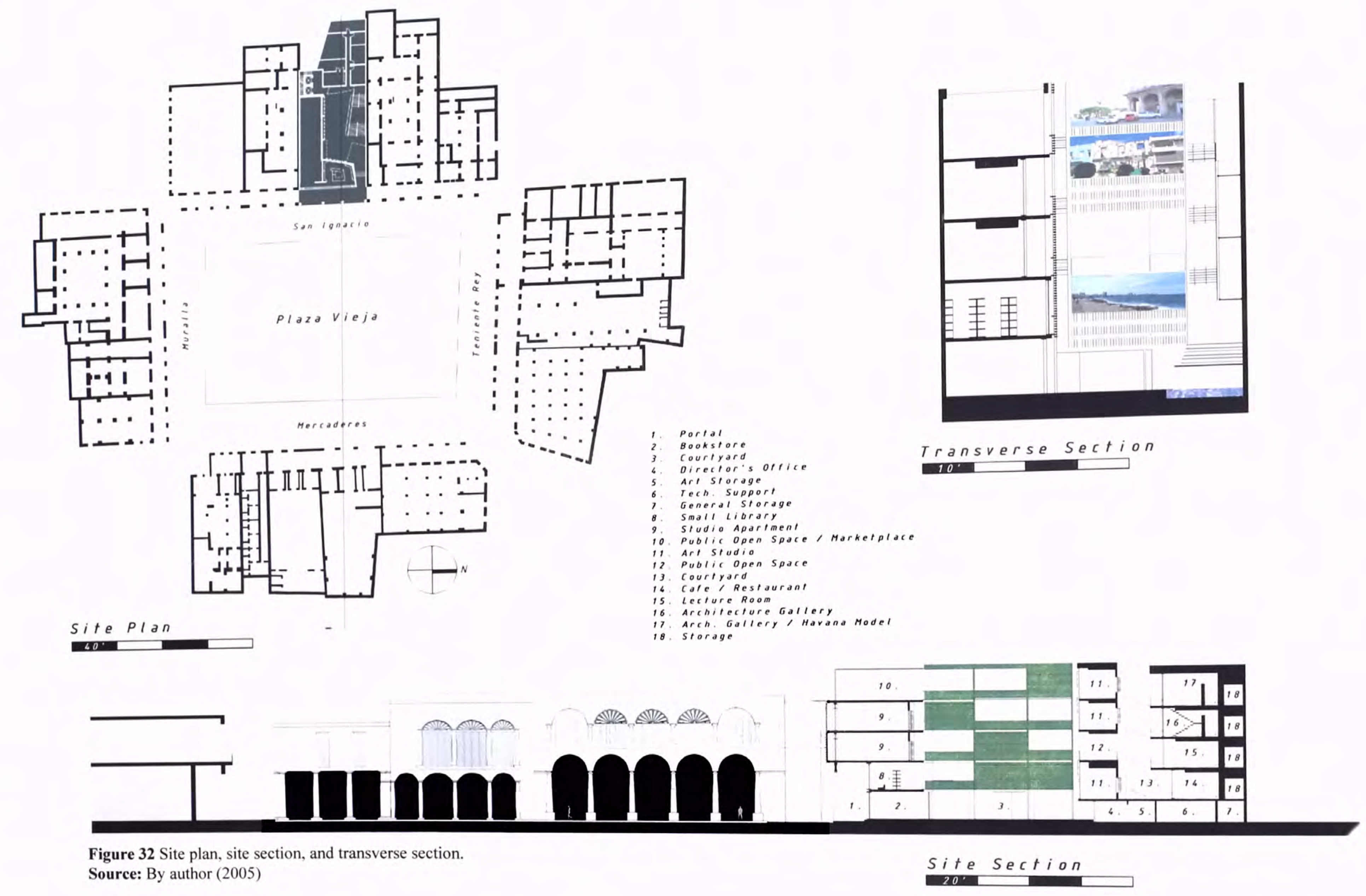




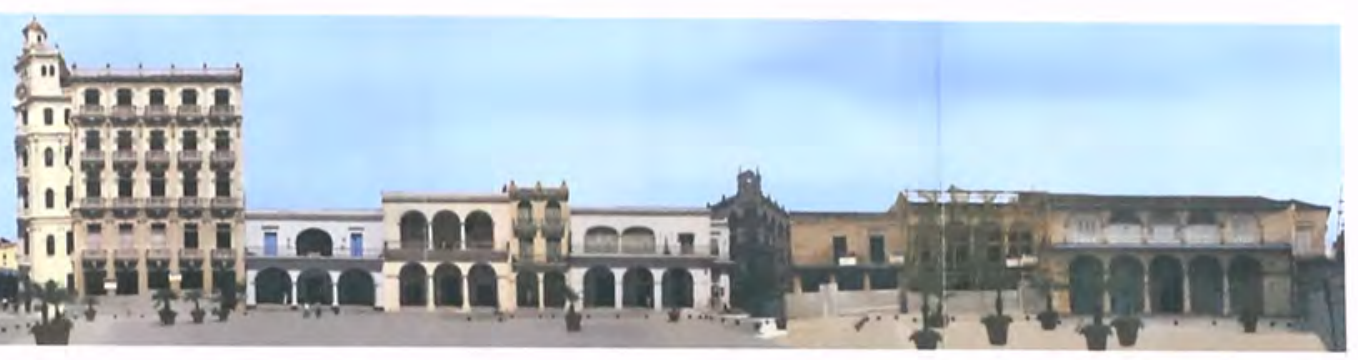

Figure 33 Proposed front elevation in context.

Source: Office of the City Historian, Havana, Cuba.

Proposed elevation by author (2005) 


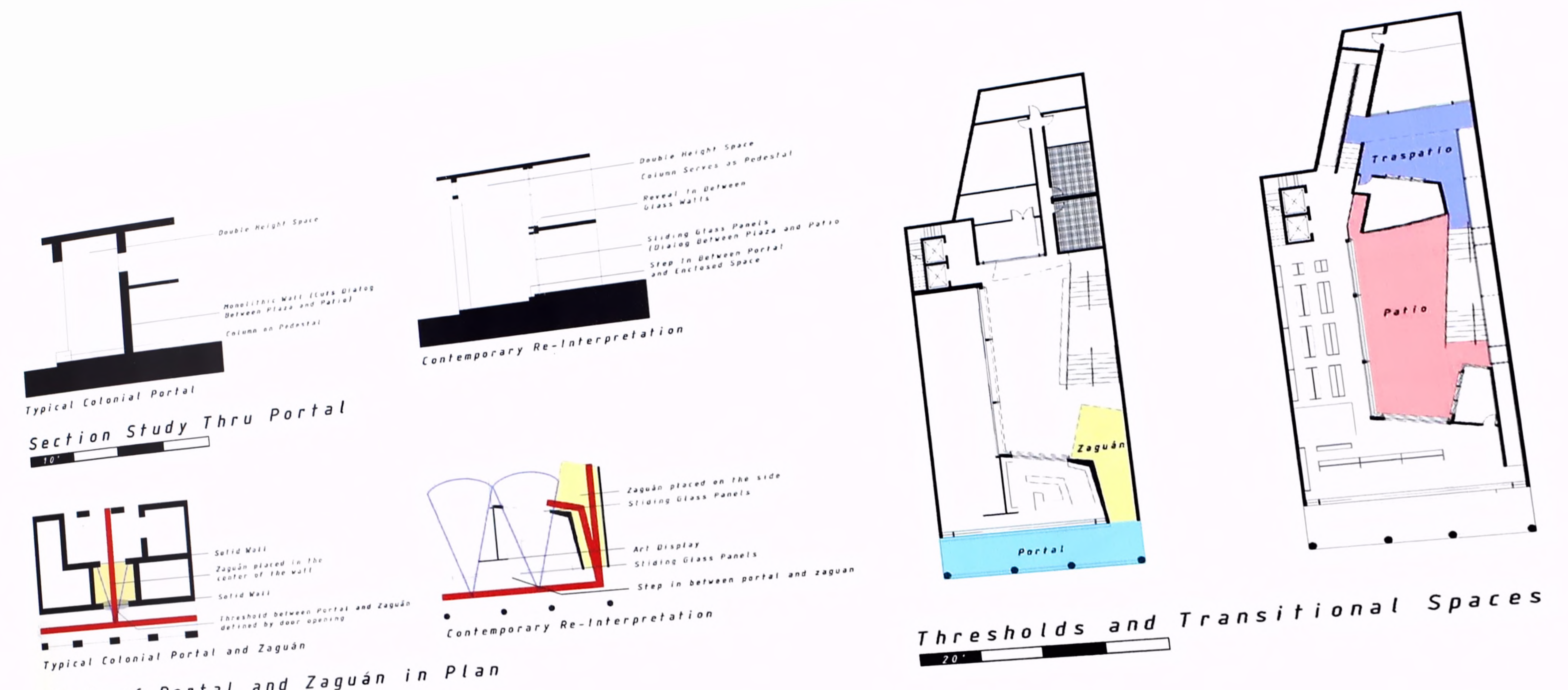

Study of Portal and Zaguán in Plan

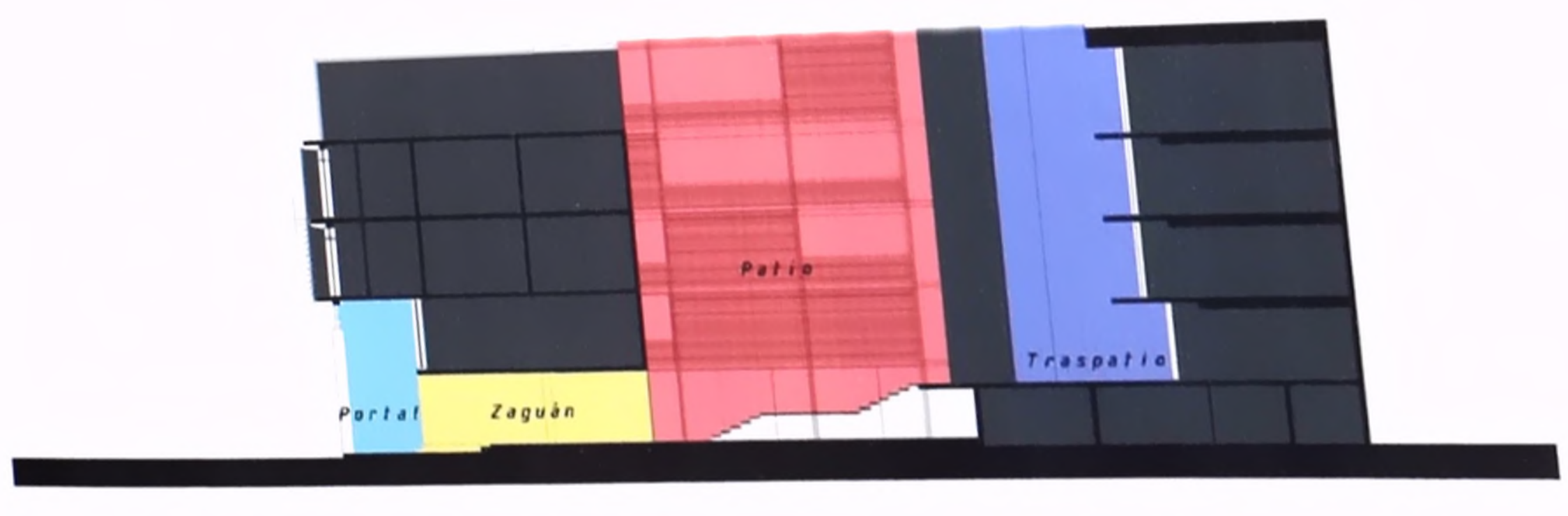

Sections Thru Thresholds and Transitional Spaces

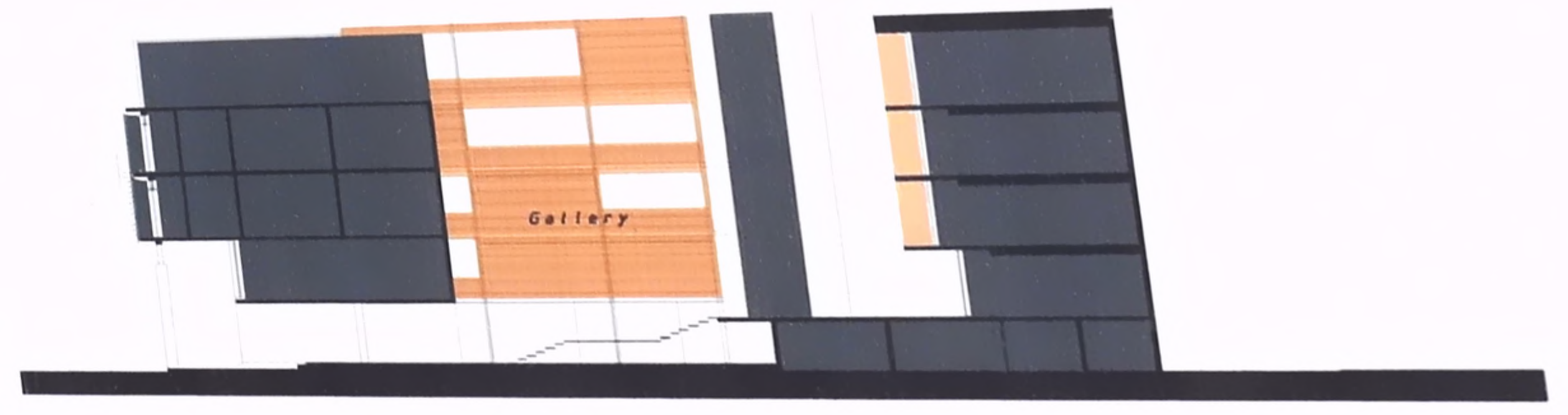
Figure 34 Threshold and transitional space studies.
Source: By author (2005) 


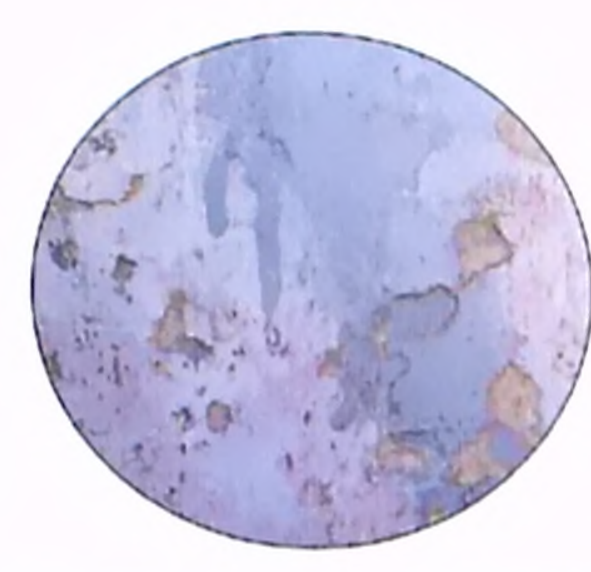

concrete, stone texture

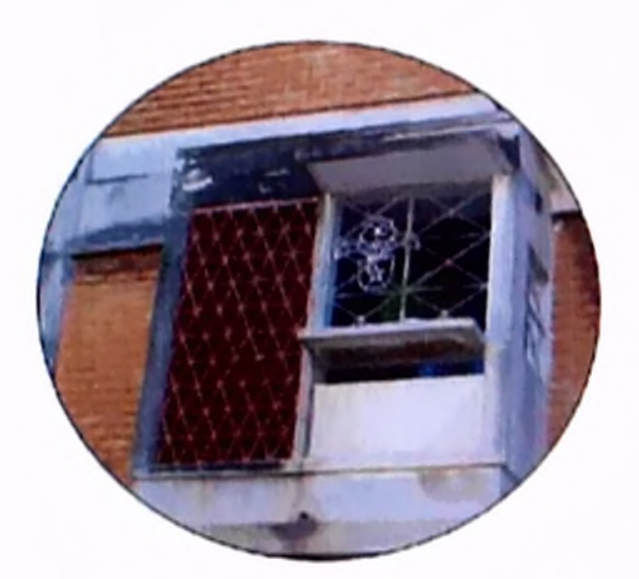

screens icelosias

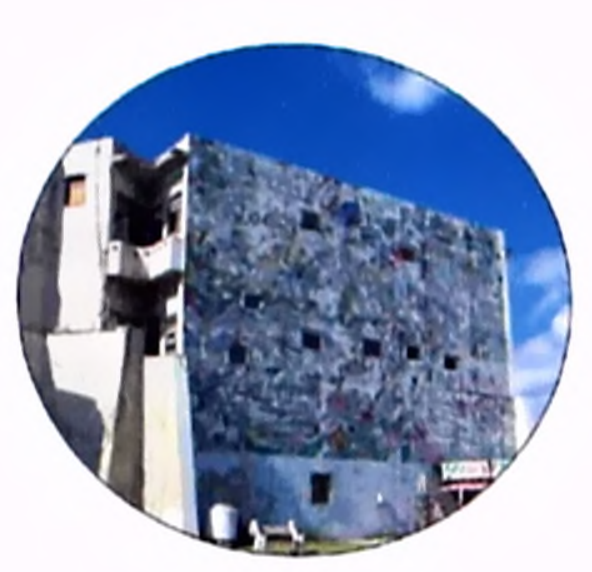

urban Ar

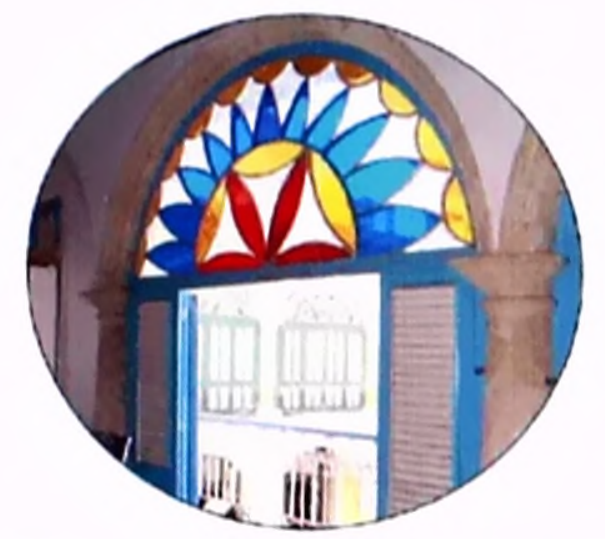

stained Glass (vitrales)

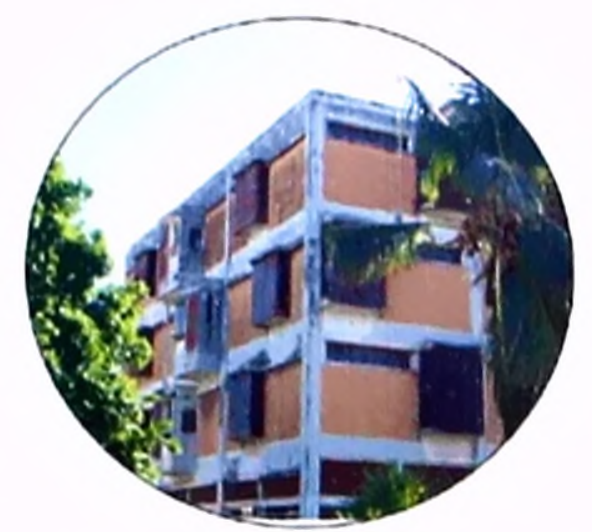

Juxtaposition of cold and

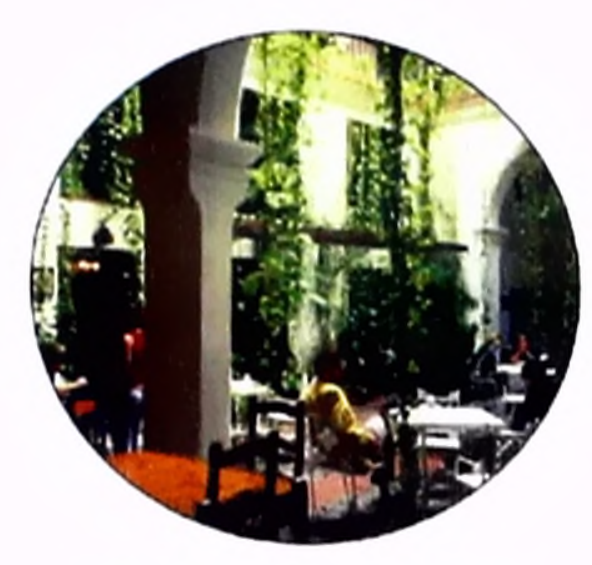

tandscaped patios

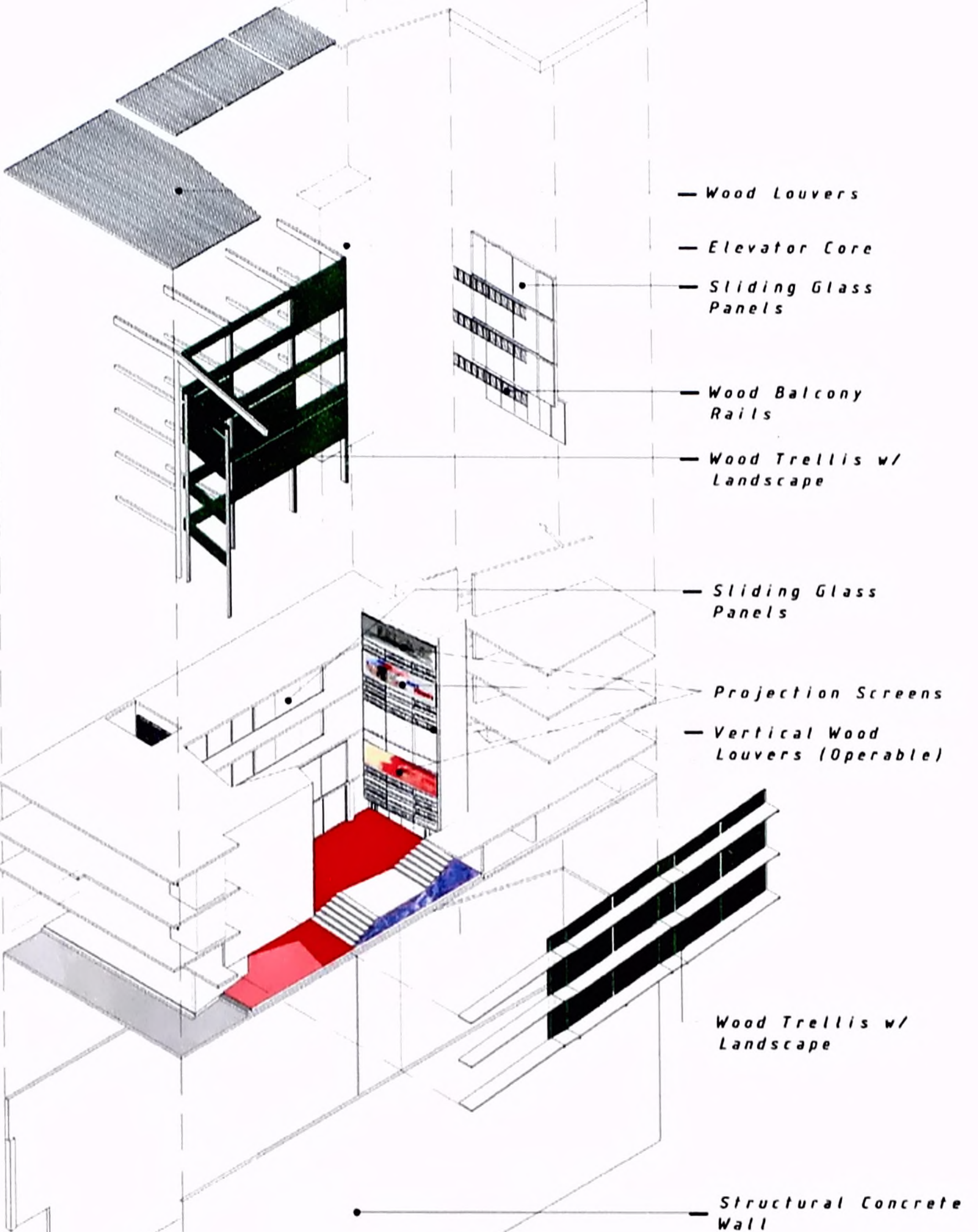

Figure 35 Exploded isometric drawing showing facade assembly, materiality, and detail as well as photographic documentation of contextual elements used and/or reinterpreted.

Source: Drawing and photograph by author (2004-2005) 

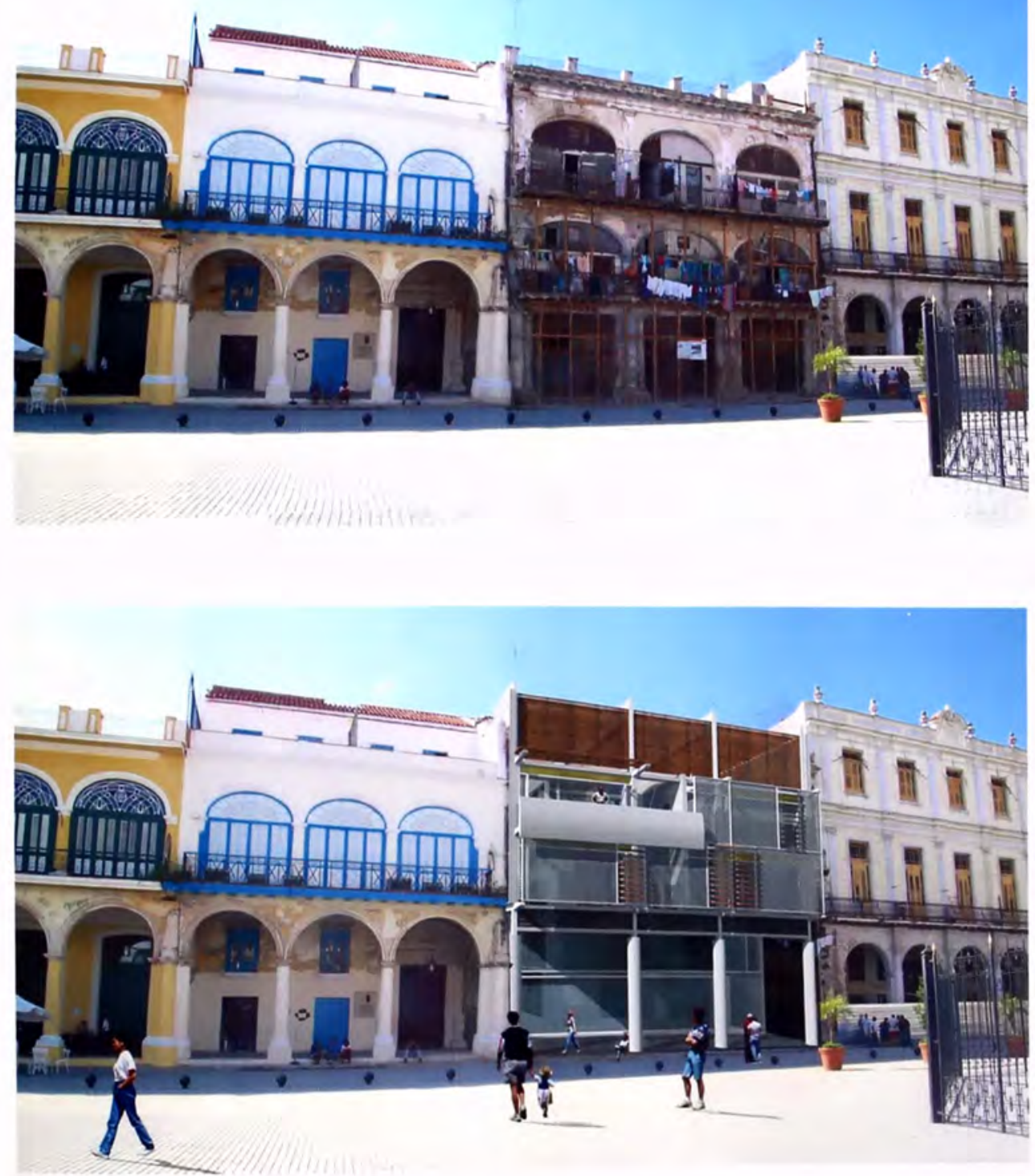

Figure 36 Plaza Vieja before and after design proposal. This thesis proposes a hypothetical situation in which the building in question collanses and there is an opportunity to design a new building in its place.

Source: Photograph and rendering by author (2004-2005) 


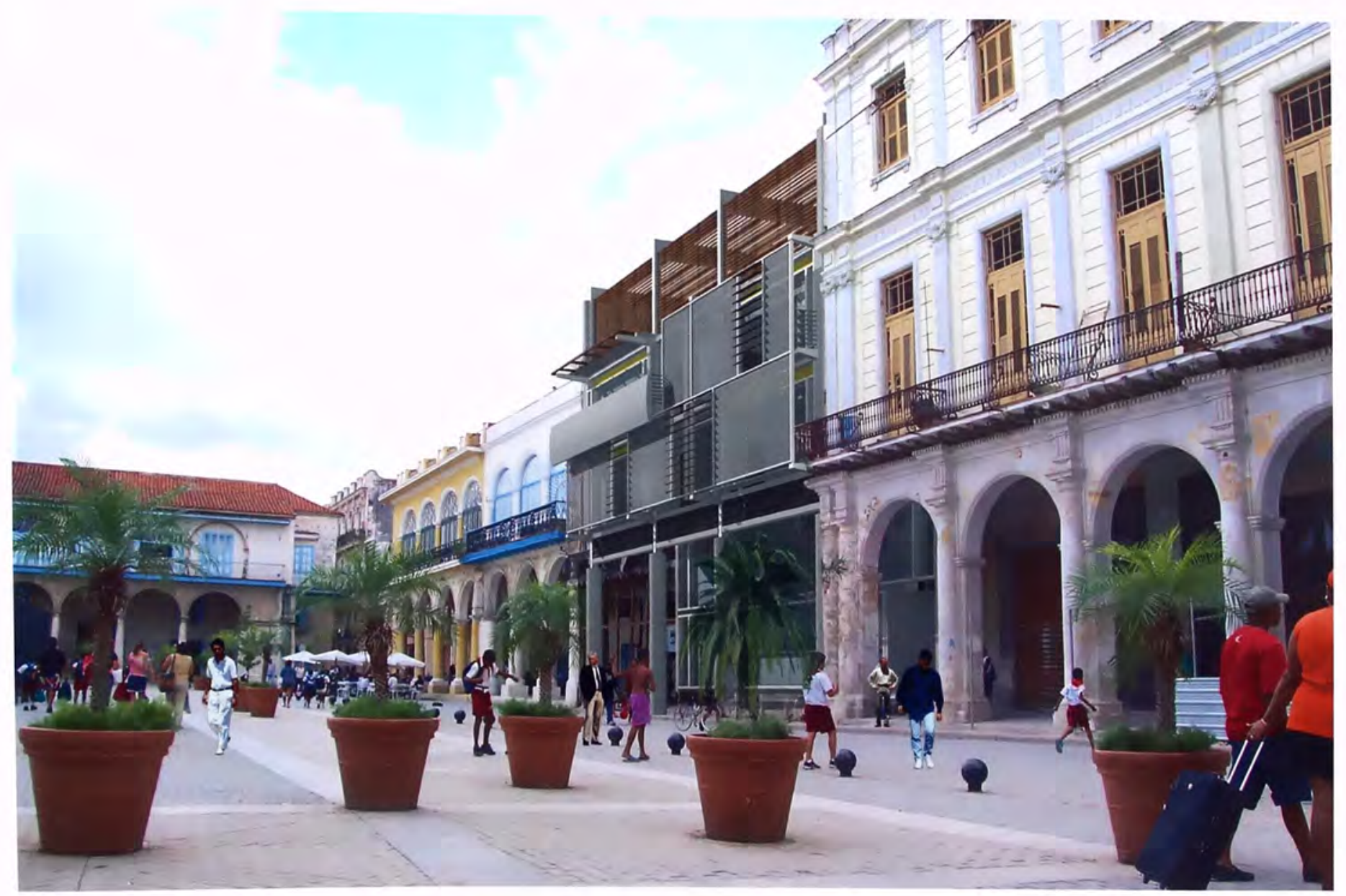

Figure 38 Photomontage

Source: Photograph and rendering by author (2004-2005) 


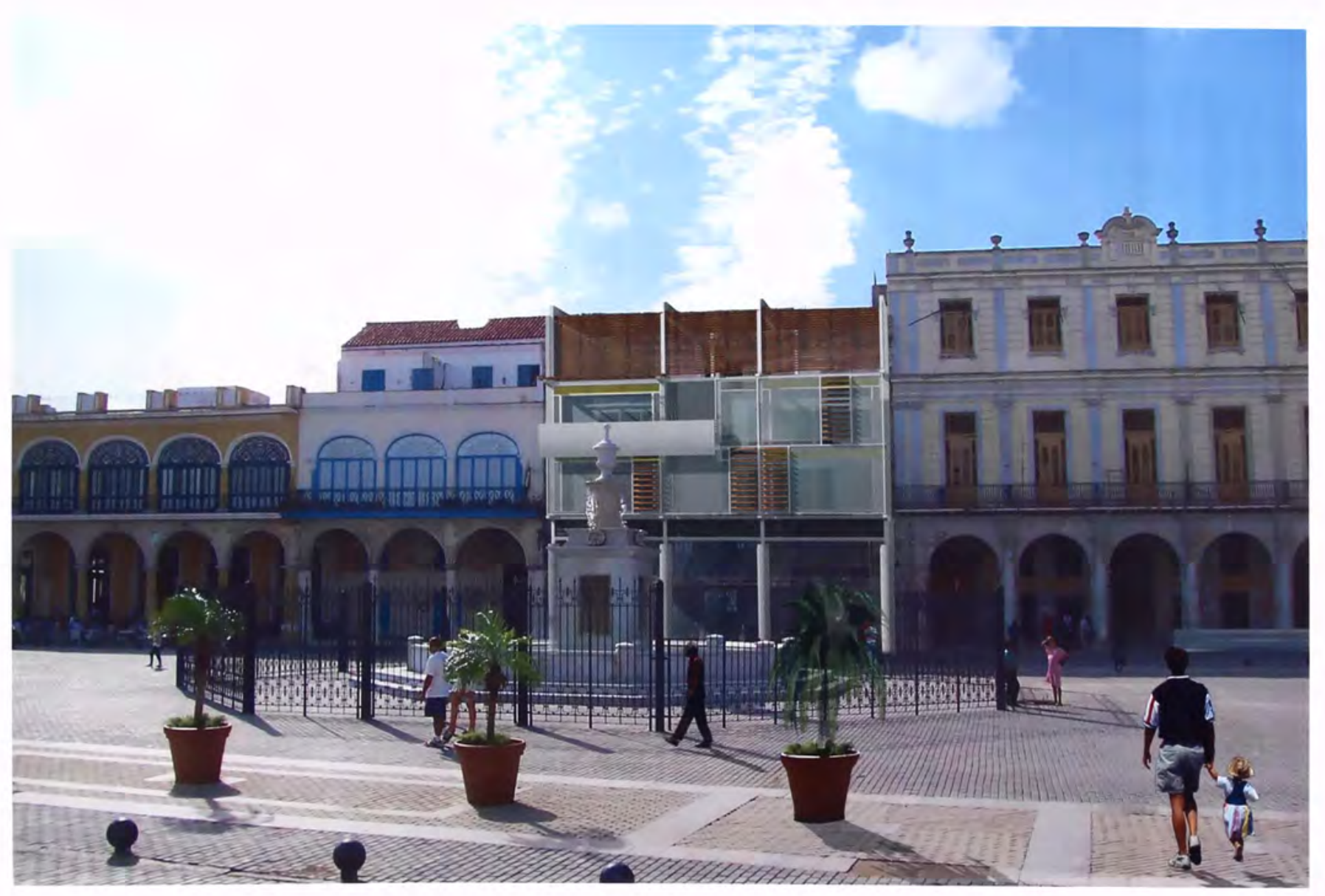

Figure 39 Photomontage

Source: Photograph and rendering by author (2004-2005) 


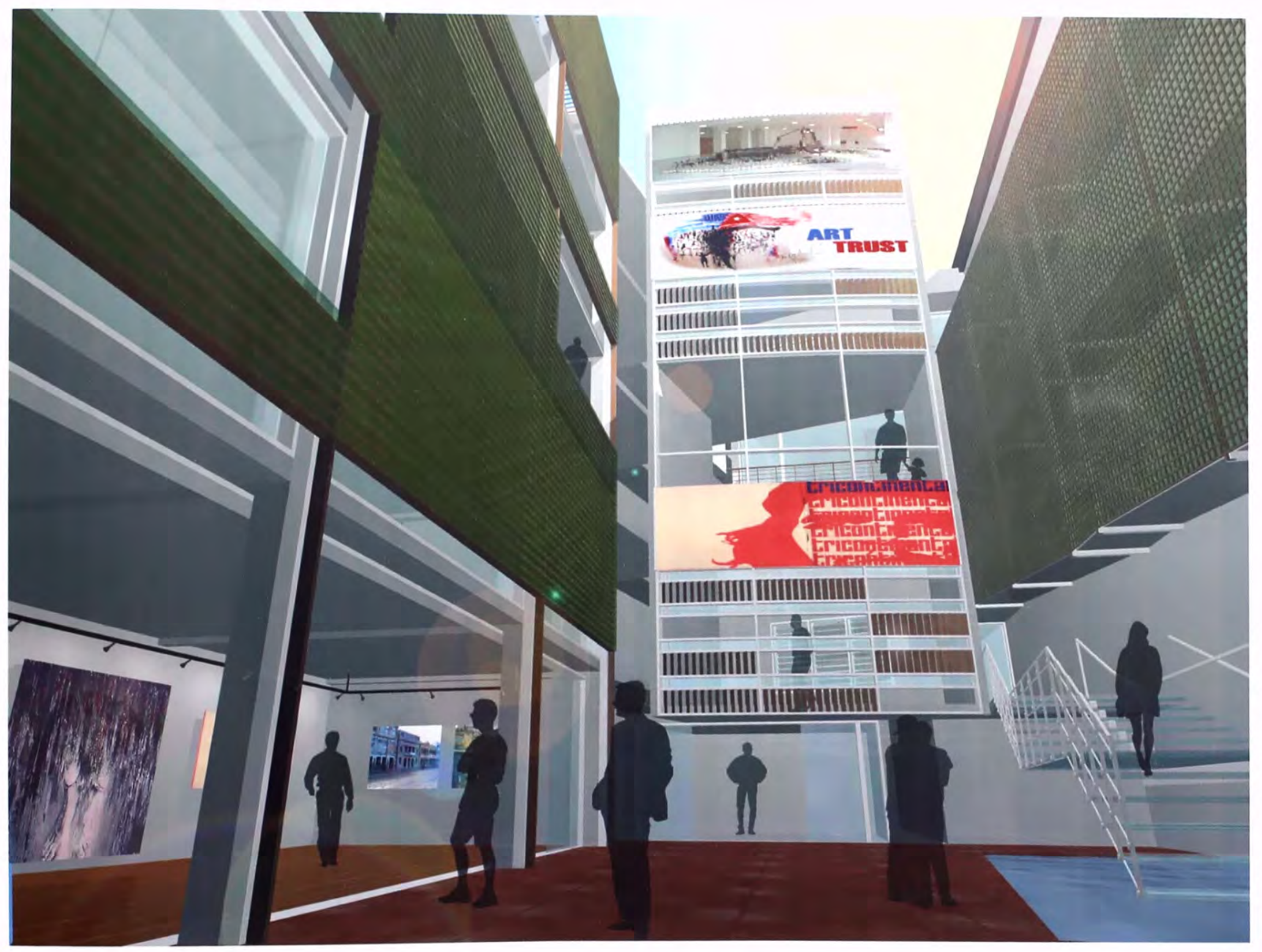

Figure 40 Digital rendering of the courtyard showing the art gallery, art studios, projection screens, grand stair, open spaces, and landscapes trellis. Notice the layering of spaces and social activities from multiple vantage points (high, low, near, far, and obour (high, and oblique). Additionally, the ar studio "lower" draws the eye upward toward the sky while the space of the courtyard slips into the art gallery and visa versa, creating a dialog between vertical and lateral space.

Source: By author (2005) 


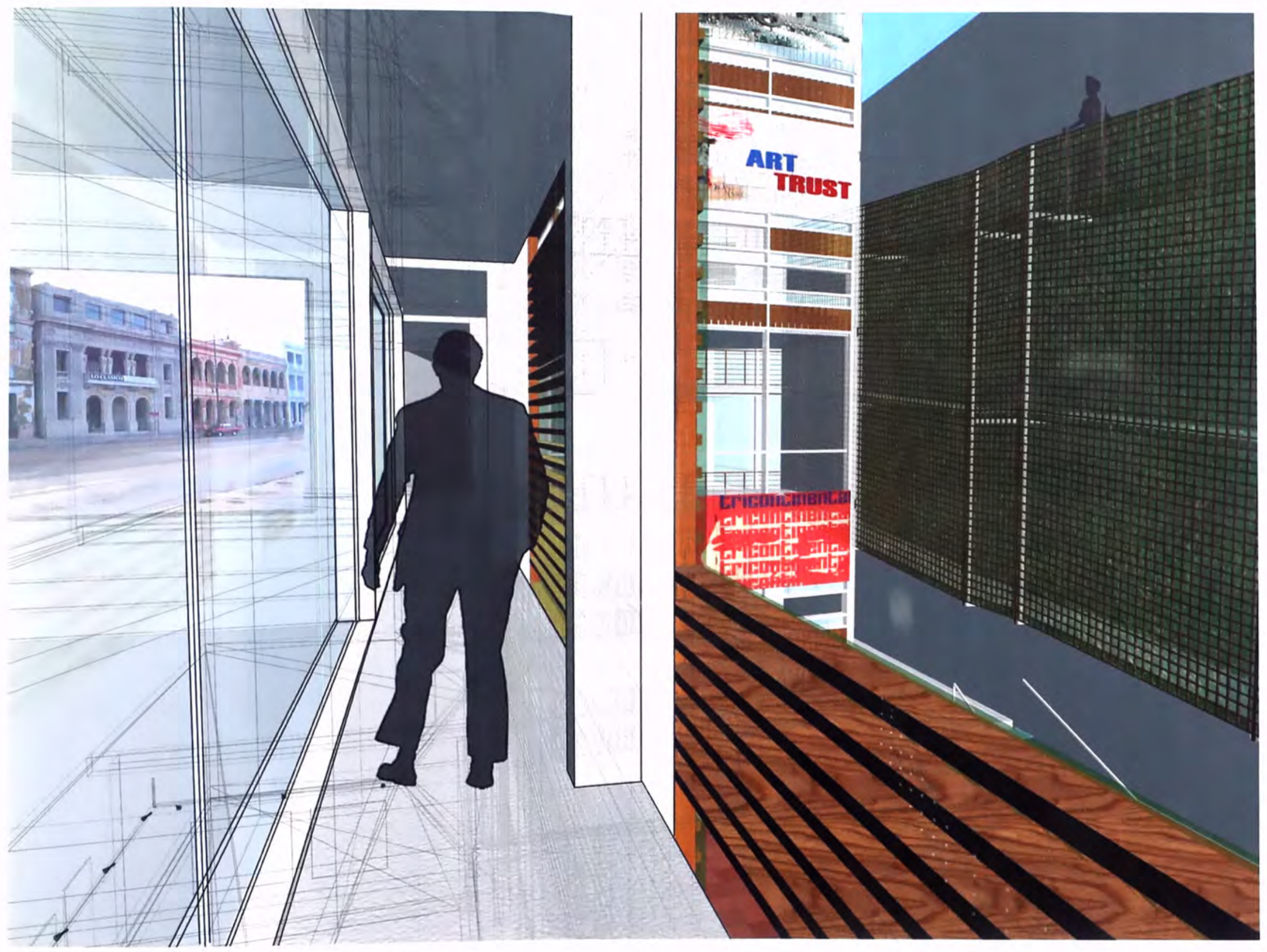

Figure 41 Digital rendering of a gallery (galeria) space. The glass panels on the left slide open, accentuating a spatial dialog between the classrooms and the open gallery space. Source: By author (2005) 


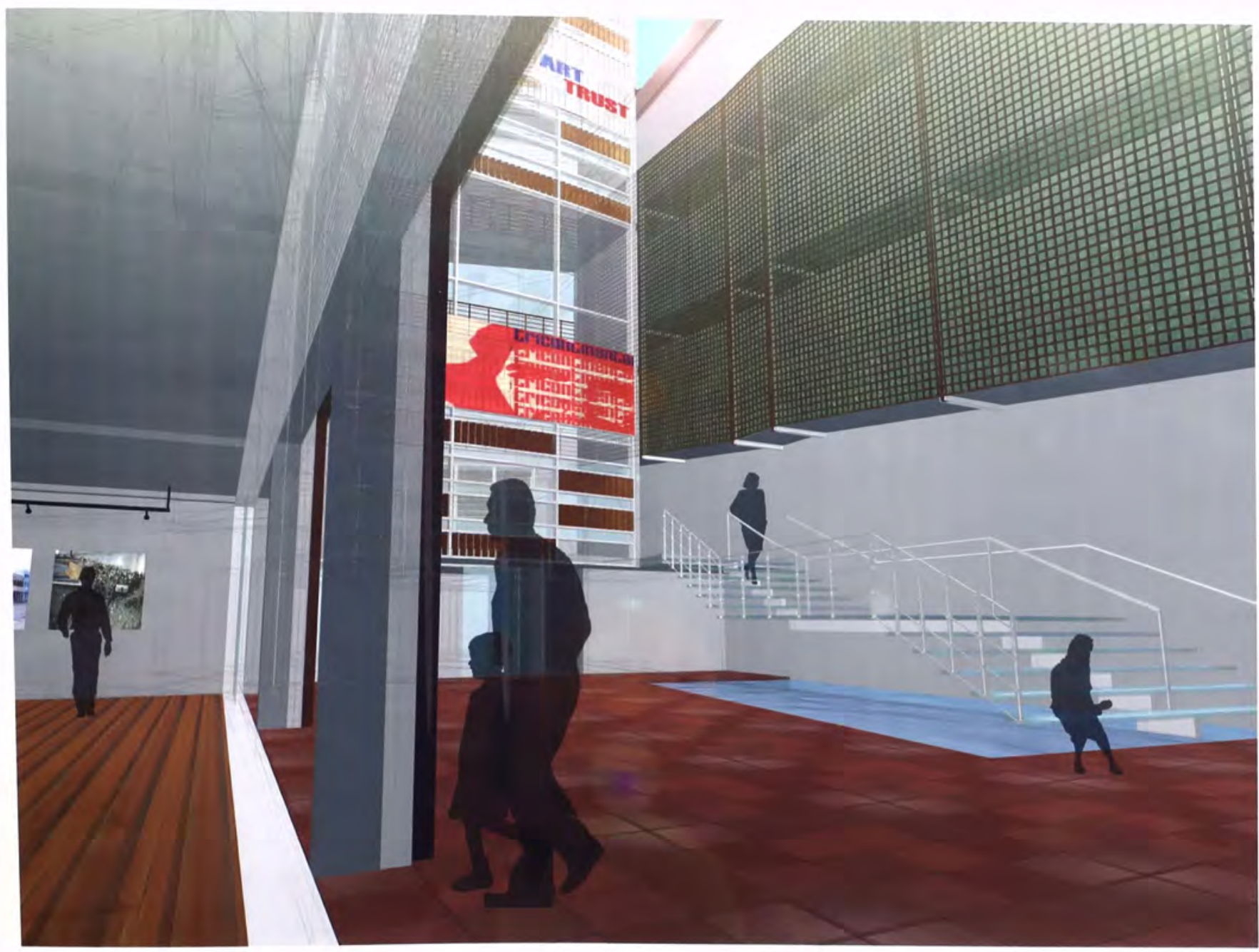

Figure 42 Digital rendering of the

courtyard emphasizing the threshold

between the public courtyard and the

semi-public art gallery.

Source: By author (2005) 


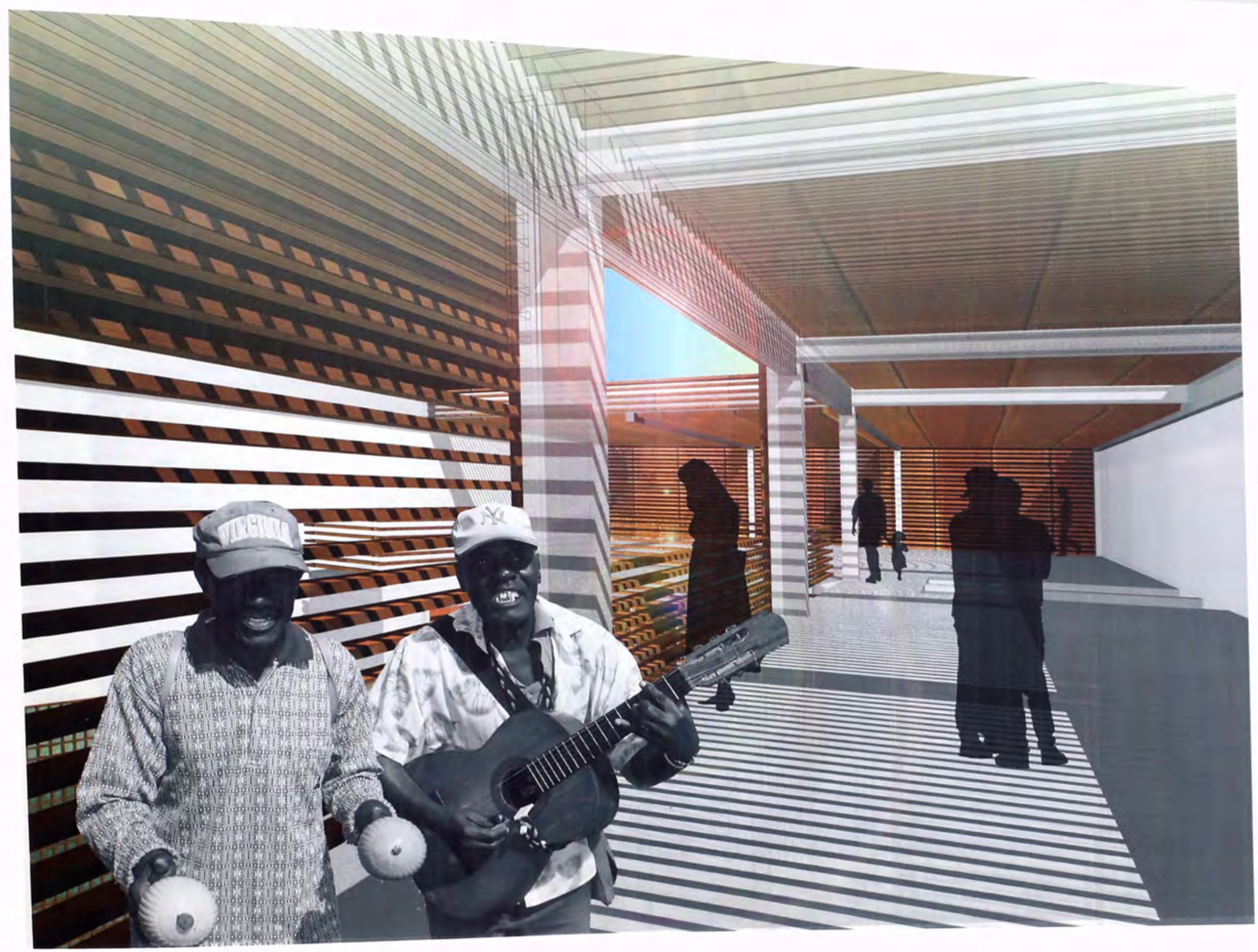

Figure 43 Digital rendering of public,

multi-functional open spaces

(marketplace)

Source: By author (2005) 


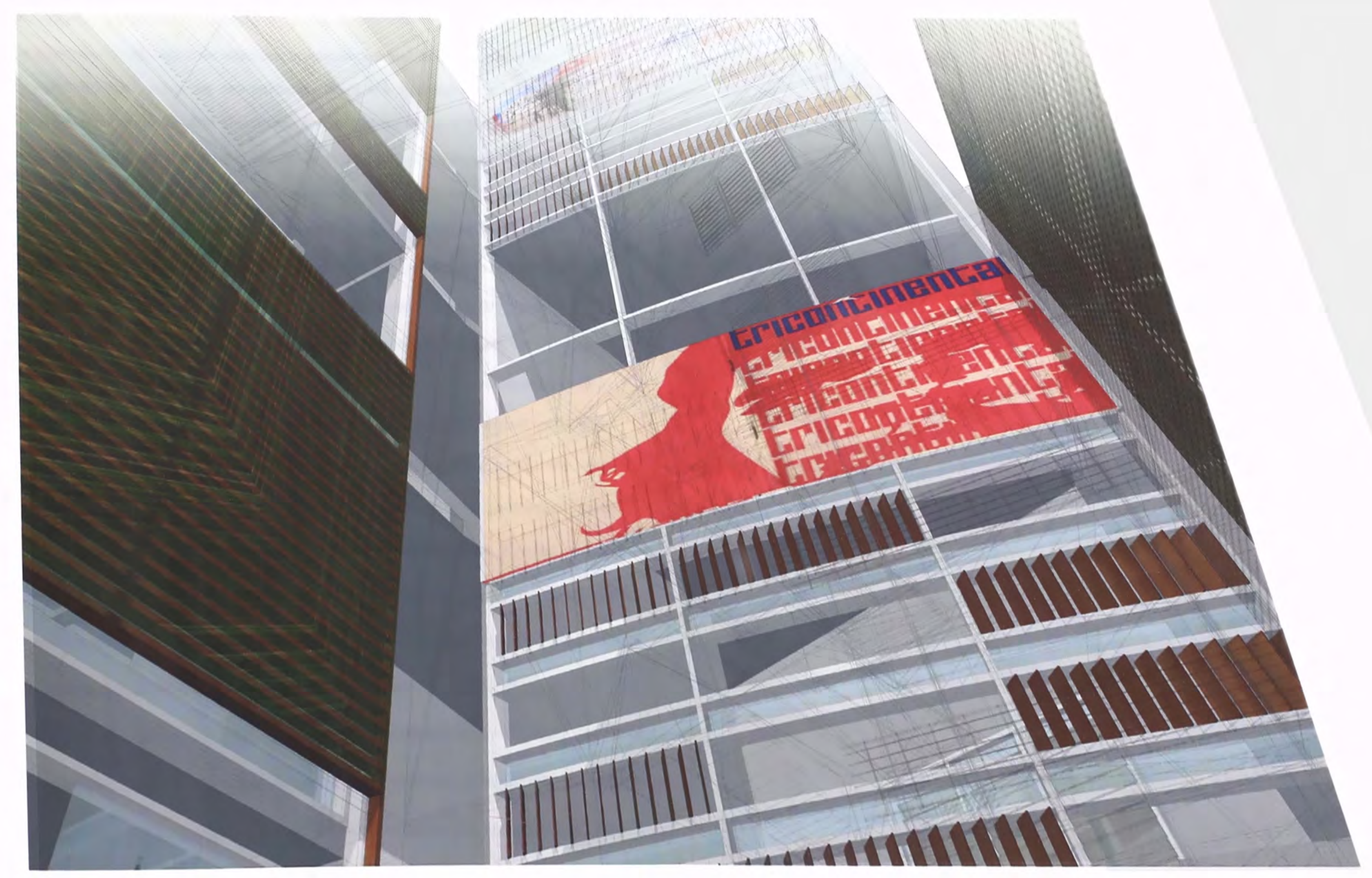

Figure 44 Detailed digital rendering of the art studios and projection screen. Notice the operable vertical louvers which allow privacy, cross ventilation and a dialog between opened and closed, concealed and revealed.

Source: By author (2005) 


\section{CONCLUSION}

This thesis makes a stand against the notion that, in order not to disrupt the poetic make-up of historically significant urban contexts, any new architecture should look as similar to the existing architecture as possible, even to the point of imitation. I argue that this theory is destructive and counter-productive in the effort of preserving historic places as it reduces the significance of historic places (its context) to mere cosmetics. Moreover, it is especially destructive to the city of Havana, which was spared a great deal of destructive overdevelopment during the second half of the $20^{\text {th }}$ century.

As a result of being spared, Old Havana has retained much of its colonial charm from both an architectural and urban standpoint and serves as an exciting testing ground to explore the core issues of this thesis; contextual re-interpretation. Rather than succumbing to stylistic imitation, the proposed cultural center draws from the city's cultural, architectural, and urban context-understanding the thresholds and transitional spaces of the colonial Cuban house (portal, zaguán, galeria, patio, and traspatio) and the city's urban character expressed through its continuous façades, stone and wood textures, public open spaces, balconies, portales, vitrales (stained glass windows), screens, and louvers

as key characteristics of Old Havana's sense of place and adapting these elements within a contemporary design language. This approach is not much different from that of the mid-twentieth century generation of Cuban architects, particularly Eugenio Batista and Mario Romañach, who engaged a synthesis between old and new in their work in search for genuine Cuban architecture.

The design of contemporary architecture in historic places remains a challenging and exciting task for architects as it falls in the middle-ground between architectural history and the continuous search for new architectural expression. It is my intent to use the lessons and principles learned form this thesis towards further research (both academic and in practice) as the issues explored apply not only to Old Havana, but to any city rich in architectural and urban history. 


\section{LIST OF REFERENCES}

Aguirre, Yolanda, Vidrieria Cubana: Lucetas y Óculos de la Habana Vicja La Habana: Instituto Cubano del Libro, 1971

Amoruso, Christina and Castillo, Orestes del

Life and Death of the Courtyard House: Migration, Metissage, and Assassination of a Typology ACSA, Oct. 1997

Barclay, Juliet, Havana: Portrait of a City

London: Cassell Villiers House, 1993

Baroni, Sergio, Havana's Architecture

Zodiac 8, Milano: Editrice Abitare Segesta Spa, 1992

Bastlund, Knud, Jose Luis Sert

New York: Fredrick A. Praeger, 1967

Batista, Eugenio, The Cuban House: Patios, Portales y Persians Translated from Spanish to English by Raúl García

Artes Plasticas, Vol. 2, 1960

Blond, José Ramón Soraluce, ed., Arquitectura De La Casa Cubana Coruña: Universidade Da Coruña, 2001

Carley, Rachel and Brizzi, Andrea, Cuba: 400 Years of Architectural Heritage New York: Whitney Library of Design, 1997

Cuba Plaza Vieja: Campaña Internacional UNESCO

La Habana: Editorial Arte y Literatura, 1983

Duany, Andres, The Future of La Habana

University of Miami, 2003

Façades of the Squares of Old Havana

Office of the City Historian

La Habana: 1990

Fornias, Carlos Venegas, La Plaza Vieja: Escenario de La Habana Arquitectura / Cuba 355-56, 1983

Fornías, Carlos Venegas, La Plaza Vieja: Historia e Identidad Arquitectura / Cuba 355-56, 1983
Fornias, Carlos Venegas, Plazas de Intramuro

La Habana: Consejo Nacional de Patrimonio Cultural, 2003

Galmiche, Xavier, Havana: Districts of Light

Paris: Vilo Publishing, 2001

Goldberger, Paul, Annals of Preservation: Bringing Back Havana

The New Yorker, Jan. 26, 1998, pp. 50-6

Gopnik, Blake, Havana's Intriguing Middle-aged Beauties Washington Post, February 8, 2004

Lerner, Jonathan, ;Viva La Revolucion! Metropolis Magazine, July 200

Lightfoot, Claudia, Havana: A Cultural and Literary Companion New York: Interlink Books, 2002

Llanes, Llilian, The Houses of Old Cuba New York: Thames \& Hudson, 1999

Lejune, Jean-Francois, The City as Landscape: Jean Claude Nicolas Forestier and the Great Urban Works of Havana, 1925-1930

Journal of Decorative and Propaganda Arts: Cuba Theme Issue, Vol. 22

Miami: Wolfson Foundation, 1996

Levinson, Nancy, Looking for Romañach

Metropolis Magazine, February, 2004

Lobo, M. L., Havana: History and Architecture of a Romantic City New York: Monacelli Press, 2000

Loomis, John A., Revolution of Forms: Cuba's Forgotten Art Schools New York: Princeton Architectural Press, 1999

Martín Zequeira, M. E., La Habana: Guia de Arquitectura

La Habana and Seville: Junta de Andalucía, 1998

Masse, E. M., L'Isle de Cuba et La Havane, Paris, 1819 Arquitectura / Cuba 355-56, 1983

Menocal, Narciso G., Lo Cubano in Cuban Architecture Herencia: El Rio de la Cultura Cubana, Vol.7, Summer 2001 
National Trust for Historic Preservation, ed.. Old and New Architecture: Design Relationship

Washington, D.C.: Preservation Press, 1981

Préstamo, Felipe J. Ed., Cuba: Arquitectura y Urbanismo

Miami: Ediciones Universal, 1995

Quintana, Nicolás, Arquitectura ('ubana (1940-1960): La Generacion Del '50

Arquitectura Cuba, 1960

Quintana, Nicolás, Cuba en su Arquitectura y Urbanismo: Los Años 50: Pasado, Presente y Futuro Herencia: El Rio de la Cultura Cubana. Vol.7, Summer 2001

Read, Gray, Theatre of Public Space: Architectural Experimentation in the Théatre de l'espace

Florida International University, 2004

Rizo, Enrique Capablanca, La Plaza Vieja: Propuesta de Restauracion

Arquitectura / Cuba 355-56, 1983

Rodríguez, Eduardo Luis, The Architectural Avant-Garde: From Art Deco to Modern Regionalism

Journal of Decorative and Propaganda Arts: Cuba Theme Issue, Vol. 22

Miami: Wolfson Foundation, 1996

Rodriguez, Eduardo Luis, The Havana Guide: Modern Architecture 1925-1965

New York: Princeton Architectural Press, 2000

Sambricio, C. and Segre, Roberto, Arquitectura en la Ciudad de La Habana: Primera Modernidad

Madrid: Sociedad Editorial Electa España S.A. de esta edición, 2000

Sapieha, Nicolas, Old Havana, Cuba

London: Tauris Parke Books, 1990

Sedeño, Mario González, Havana: It is and it isn

Arquitectura y Urbanismo, Vol. XII, No. 3, 1991

Warren, John, Ed., Worthington, John, ed., Taylor, Sue, ed.,

Context: New Buildings in Historic Settings

Oxford: Architectural Press, 1998

Weiss, Joaquin, La Arquitectura Colonial Cubana

La Habana: Editorial Letras Cubanas, 1979

Weiss, Glenn, The Architecture of Havana

November, 1998 